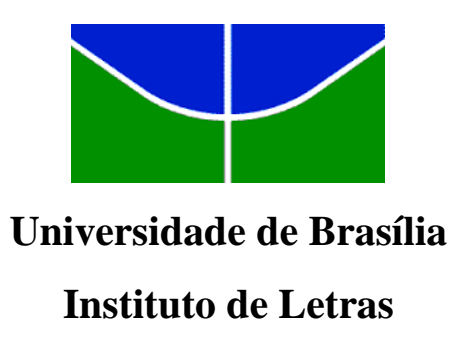

Departamento de Linguística, Português e Línguas Clássicas

Programa de Pós-Graduação em Linguística

\title{
SOBRE A EMERGÊNCIA DA INVERSÃO LOCATIVA NO PORTUGUÊS DO BRASIL
}

Jonathan Furtado Pedroza

Brasília - DF 


\section{Jonathan Furtado Pedroza}

\section{SOBRE A EMERGÊNCIA DA INVERSÃO LOCATIVA NO PORTUGUÊS DO BRASIL}

Dissertação apresentada ao Departamento de Linguística, Português e Línguas Clássicas da Universidade de Brasília como requisito parcial para obtenção do grau de Mestre em Linguística.

Orientadora: Dra ${ }^{\mathrm{a}}$ Eloisa Nascimento Silva Pilati 


\section{SOBRE A EMERGÊNCIA DA INVERSÃO LOCATIVA NO PORTUGUÊS DO BRASIL}

Dissertação apresentada ao Departamento de Linguística, Português e Línguas Clássicas da Universidade de Brasília como requisito parcial para obtenção do grau de Mestre em Linguística.

Área de concentração: Teoria e Análise Linguística

Linha de pesquisa: Gramática - Teoria e Análise

Dissertação aprovada em 23 de fevereiro de 2015.

\section{Comissão examinadora:}

Prof $^{\text {a }}$. Dr ${ }^{\mathrm{a}}$. Eloisa Nascimento Silva Pilati

Universidade de Brasília (UnB) - presidente

Prof ${ }^{a}$. Dr ${ }^{\mathrm{a}}$ Heloisa Maria Moreira Lima de Almeida Salles

Universidade de Brasília (UnB) - membro

Prof $^{a}$. Dr ${ }^{\mathrm{a}}$. Maria Cristina Figueiredo Silva

Universidade Federal do Paraná (UFPR) - membro

Prof. Dr. Marcus Vinicius da Silva Lunguinho

Universidade de Brasília (UnB) - suplente 
À minha família e aos meus amigos. 


\section{AGRADECIMENTOS}

A Deus (Pai, Filho e Espírito Santo) e a São Bento, pela proteção divina.

À minha orientadora, Eloisa Pilati, pela paciência e pelos ensinamentos acadêmicos.

Aos professores Heloisa Salles, Rozana Naves, Helena Guerra, Marcus Lunguinho e Marina Magalhães, pelos conteúdos ministrados durante esses dois anos de Mestrado.

À professora Walkíria Neiva Praça, pela presteza.

À professora Maria Cristina Figueiredo Silva, pelas contribuições a esta dissertação.

À Ângela e à Renata, pela atenção que sempre tiveram comigo nos atendimentos na secretaria do PPGL.

À minha amiga Mirze Melo, pelo incentivo à iniciação do Mestrado.

À minha amiga Manuela Luna, pelo companheirismo, pelas conversas e pelas constantes ajudas.

Ao meu amigo Francisco Eduardo, pelos grandes ensinamentos.

À minha amiga Nayara dos Anjos, pela motivação constante.

À minha amiga Josemília, pelas conversas e pela motivação.

Às minhas amigas Kauna Rener e Érika Conti, pelas conversas e pelo companheirismo.

Aos meus compadres Kleyson e Andresa, pela amizade e pelo meu afilhado Bernardo.

À minha família - em especial à minha mãe, ao meu pai e ao meu irmão -, pela motivação. 
"O que vale na vida não é o ponto de partida e sim a caminhada. Caminhando e semeando, no fim terás o que colher." 


\section{RESUMO}

A presente pesquisa examina aspectos sintáticos e semânticos de sentenças com ordem verbosujeito (VS) no português brasileiro (PB) na região Centro-Oeste durante o século XIX. Dada a hipótese de que o processo sócio-histórico favoreceu situações específicas de contatos e de isolamentos social e linguístico [cf. Borges, Salles \& Pilati (2012)], o objetivo geral do estudo é o de investigar se houve influência desse isolamento linguístico no licenciamento da ordem VS. Para tanto, o presente trabalho realiza uma investigação quantitativa no Jornal Matutina Meyapontense, impresso local produzido no final do século XVIII e durante o século XIX, e compara os dados obtidos com as análises provenientes das pesquisas diacrônicas de Berlinck (1989) e de Gravina (2014). Nessa comparação são verificados aspectos em comum e aspectos em divergência. $O$ presente trabalho apresenta também os resultados das análises quantitativas efetuadas no corpus escrito do Jornal Matutina Meyapontense sobre as orações na ordem $(\mathrm{X}) \mathrm{VS}$, com X manifesto ou nulo. Em relação ao aspecto qualitativo, o presente trabalho defende que, já no século XIX, no centro-oeste brasileiro, as orações na ordem VS poderiam ser inversão locativa, como defende Pilati (2006) para os dados do PB atual. Defende-se também, como proposto por Corr (2012), que não há relação entre inversão locativa e parâmetro pro-drop.

Palavras-chave: Ordem VS; Inversão locativa; Português Centro-Oeste; Diacronia; Parâmetro pro-drop. 


\begin{abstract}
This dissertation examines syntactic and semantic aspects of sentences with verb-subject order (VS) in Brazilian Portuguese (BP) in the Midwest region during the XIX Century. Based on the hypothesis that the socio-historical process favored specific situations of contacts and social and linguistics isolations [cf. Borges, Salles \& Pilati (2012)], the general objective of this study is to investigate whether there was influence of linguistic isolation in licensing the VS order. Therefore, this dissertation makes a quantitative analysis in the Matutina Meyapontense Journal, local impress produced in the late XVIII Century and during the XIX Century, and compares the data obtained from the analysis of the diachronic research Berlinck (1989) and Gravina (2014). In this comparison are checked aspects in common and aspects at odds. This paper also presents the results of quantitative analysis carried out in the corpus of written Matutina Meyapontense Journal on clauses in the (X)VS order, with X manifest or null. Regarding the qualitative aspect, this paper argues that, in the XIX Century, in midwestern Brazil, the clauses in the VS order could be locative inversion, as argued by Pilati (2006) for information on the current PB. This paper defends also, as proposed by Corr (2012), that there isn't relationship between locative inversion and pro-drop parameter.
\end{abstract}

Keywords: VS order; Locative inversion; Portuguese Midwest; Diachronic; Pro-drop parameter. 


\section{SUMÁRIO}

INTRODUÇÃO.

CAPítulo 1 - A TEORIa gerativa E A ORDEM VS NO PORTUguêS BRASILEIRO.

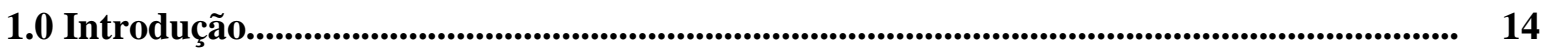

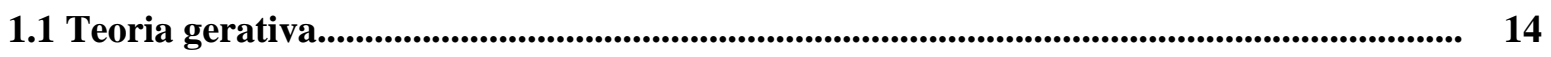

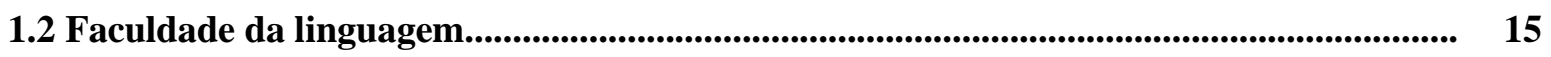

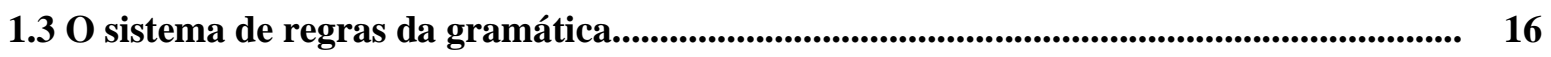

1.4 Gramática Universal: princípios e parâmetros................................................................. 18

1.5 Princípio de Projeção Estendida.................................................................................... 19

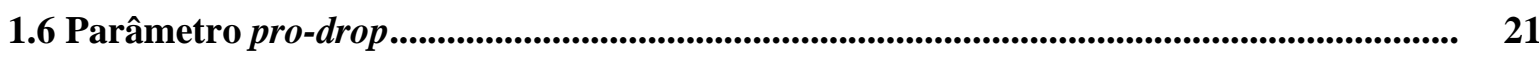

1.7 A ordem VS no português brasileiro.............................................................................. 24

1.7.1 A proposta de Berlinck (1989): o decréscimo da ordem VS, especialmente com

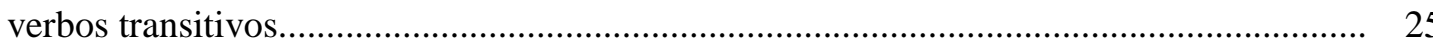

1.7.2 A proposta de Nascimento (1984): ordem VS como "interpretação de lista" e apenas com verbos inergativos e inacusativos.

1.7.3 A proposta de Kato \& Tarallo (1987): ordem VS com verbos inacusativos, com verbos não-inacusativos e com sujeitos definidos.

1.7.4 A proposta de Kato \& Tarallo (1993): ordem VS como resultado de diferentes estruturas.

1.7.5 A proposta de Pilati (2002): ordem VS como resultado de diferentes estruturas, inclusive com verbo transitivo e objeto manifesto.

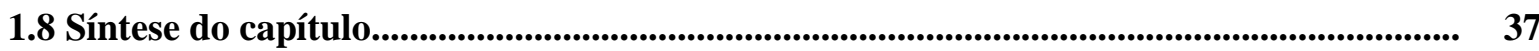

CAPÍTULO 2 - INVERS̃̃O LOCATIVA NO PORTUGUÊS BRASILEIRO............................... 39

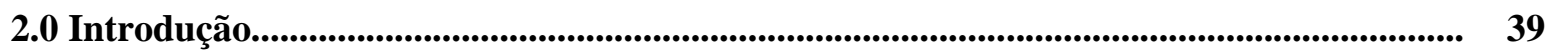

2.1 O estudo de Levin \& Rappaport (1995) sobre inversão locativa........................................ 39

2.2 Alguns estudos sobre inversão locativa no português brasileiro........................................ 41

2.2.1 A análise de Pilati (2002)...................................................................................... 41

2.2.2 A análise de Pilati (2006).............................................................................. 42

2.2.3 A análise de Corr (2012)..................................................................................... 46

2.2.3.1 Ordem VS com verbos transitivos.............................................................. 48

2.2.3.2 Ordem VS com verbos intransitivos sem alternância de ordem................. 49

2.2.3.3 Ordem VS com verbos intransitivos com alternância VS / SV................... 51

2.2.4 A análise de Gravina (2014).................................................................................... 53

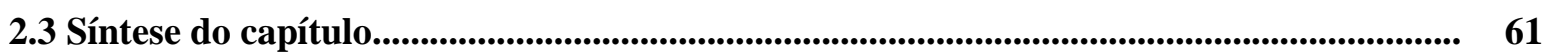


CAPÍTULO 3 - ANÁLISE DA ORDEM VS NO CENTRO-OESTE BRASILEIRO NO

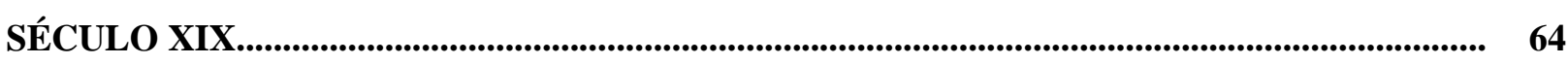

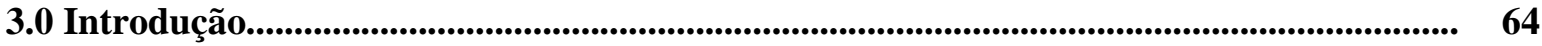

3.1 Contato de línguas no centro-oeste brasileiro...................................................................64

3.1.1 Língua Geral Paulista................................................................................................. 65

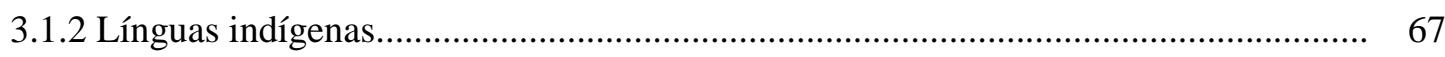

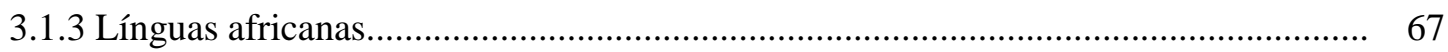

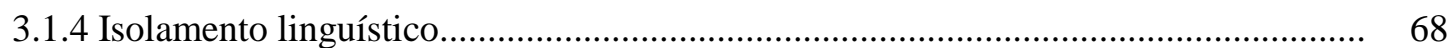

3.2 Constituição do corpus.......................................................................................................................... 69

3.3 Metodologia da apresentação dos dados....................................................................................... 70

3.4 Análise descritiva dos dados........................................................................................................ 73

3.4.1 Ordem VS em orações parentéticas.......................................................................... 73

3.4.2 Ordem VS com verbos transitivos........................................................................ 75

3.4.3 Ordem VS com verbos inacusativos....................................................................... 81

3.4.4 Ordem VS com verbos ser/estar.......................................................................... 86

3.4.5 Ordem VS com verbos inergativos................................................................. $\quad 90$

3.5 Inversões locativas nos dados do corpus....................................................................... 91

3.6 Inversão locativa e parâmetro pro-drop......................................................................................... 94

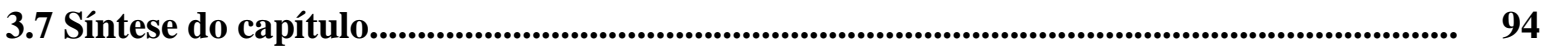

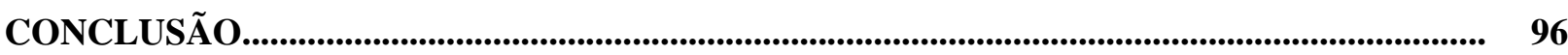

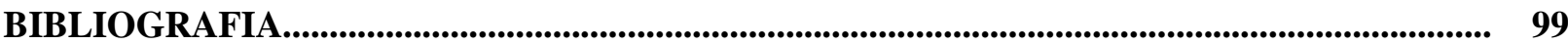




\section{INTRODUÇÃO}

O presente trabalho, sob a perspectiva da Teoria Gerativa, examina aspectos sintáticos e semânticos de sentenças com ordem verbo-sujeito (VS) no português brasileiro (PB) na região Centro-Oeste durante o século XIX. Dada a hipótese de que o processo sóciohistórico favoreceu situações específicas de contato e de isolamento linguístico [cf. Borges, Salles \& Pilati (2012)], o objetivo geral do estudo é o de investigar se esse contexto de suposto isolamento favoreceu o licenciamento da ordem VS. Além disso, pretende-se analisar quantitativamente os contextos de oração na ordem VS e a relação entre essa ordem e o parâmetro pro-drop.

A região Centro-Oeste brasileira, ao final do século XVIII, apresentava um novo tipo de povoamento, sobretudo no sul da capitania de Goiás. Segundo Chaim (1974), os campos de pastagens naturais foram transformados em centros de criação. Borges (2008) destaca que, para ocorrer uma expansão econômica, houve a necessidade de tomar dos índios as áreas sob seu domínio, o que acarretou o quase total desaparecimento dos falantes das línguas ameríndias.

A partir do século XIX, em decorrência principalmente da ausência de novas descobertas de minas de ouro, a população da região Centro-Oeste - composta por índios nativos, portugueses, africanos e mestiços - foi reduzida progressivamente. Essa situação levou os habitantes da região a migrarem para outros locais do Brasil onde ainda havia extração aurífera (CHAIM, 1974).

Com o extermínio dos indígenas e o fim da mineração, houve a cessação do fluxo de bandeirantes para a região, e, consequentemente, da Língua Geral Paulista, já que esses indivíduos foram à procura de ouro e de índios em outras localidades. No entanto, o estudo de Borges (2008) destaca que, em meados do século XIX, um novo tipo de povoamento no Centro-Oeste foi estabelecido através de duas vias de penetração na região: (i) a de 'cima', originária da região Nordeste, com criadores de gado que se espalharam pelo oeste da Bahia, através do rio São Francisco, penetrando nas fronteiras de Goiás; e (ii) a de 'baixo', originária de São Paulo, de Minas Gerais e da região Sul, que penetrou no território goiano através dos antigos caminhos da mineração e se estabilizou no sudoeste da região.

Apesar desse novo tipo de povoamento, na região ainda imperava a dificuldade de comunicação com as outras regiões brasileiras, o que refletia negativamente sobre o fluxo imigratório. Borges (2008) mostra que, devido às enormes distâncias que separavam a 
província dos portos do litoral e à pobreza para se construir vias de acesso à região, Goiás e sua comunidade linguística ficaram relativamente isoladas do restante do país.

Nesse período de suposto isolamento linguístico por que passava a região Centro-Oeste brasileira, cabe mencionar, baseado exemplificativamente em dados extraídos do Jornal Matutina Meyapontense (impresso local do século XIX), que havia realizações de sentenças com ordem VS. Nesse sentido, confira-se em (1):

(1) a. Nos Calamitosos tempos de Manoel Ignacio de Sampaio chegava o Correio sempre de noite(...)

b. Ignora $o$ Sr. Redactor o facto do Rebouças, de que fui testemunha ocular (...)

c. Aqui desperdiça $o$ Sr. Zellozo hum Latinorio.

Nesse ponto cabem as seguintes indagações: (i) o que determinava a realização da ordem VS, dado o suposto contexto de isolamento linguístico naquela região? e (ii) quais os contextos de ocorrência da ordem VS?

Sobre o fenômeno da ordem VS, particularmente no português brasileiro (PB), Berlinck (1989), funcionalista, afirma que a ordem VS diminuiu com o decorrer do tempo, especialmente com verbos transitivos. Nascimento (1984), Kato \& Tarallo (1987) e de Kato \& Tarallo (1993) afirmam, respectivamente, que a ordem VS: (i) deve ser entendida como "interpretação de lista", ocorrendo apenas com verbos inergativos e inacusativos e (ii) seria resultado de diferentes estruturas. Pilati (2002), por sua vez, afirma que ordem VS é, sim, resultado de diferentes estruturas, inclusive com verbos transitivos e objeto(s) manifesto(s).

Os trabalhos de Berlinck (1989), Nascimento (1984), Kato \& Tarallo (1987) e de Kato \& Tarallo (1993) mostraram que o fenômeno da ordem VS estava diretamente relacionado ao parâmetro pro-drop, com exceção de Pilati (2002), que começa a observar que as orações na ordem VS eram inversões locativas, e que, portanto, não tinham qualquer relação com o parâmetro pro-drop. É importante destacar que, já em Berlinck (1989), sem as observações iniciais de Pilati (2002), os casos de VS que ainda persistiam no PB não eram apenas de VS clássico, como o das demais línguas românicas, mas alguns eram casos de inversão locativa, um fenômeno não previsto dentro do parâmetro.

Pilati (2002) e Pilati (2006) defendem que, no PB, o fato de haver sempre um $\mathrm{X}$ (manifesto ou nulo) à esquerda do verbo faz com que orações na ordem VS se pareçam inversões locativas. 
Pilati (2002) e Pilati (2006) afirmam que orações com ordem VS:

(i) não são usadas em contextos de respostas a perguntas $Q u$ com foco estreito, ocorrendo, portanto, em contextos de foco largo:

(2) A: Quem dormiu / Quem comeu o bolo?

$\mathrm{B}_{1}$ : Foi a Bruna (que dormiu / que comeu o bolo).

$\mathrm{B}_{2}$ : A Bruna.

$\mathrm{B}_{3}: *$ Dormiu a Bruna / *Comeu o bolo a Bruna.

(ii) são licenciadas com mais frequência com verbos inacusativos, como atesta a maioria dos estudos variacionistas (cf. Lira, 1986; Berlinck, 1989; Pezatti, 1993; Coelho, 2000; Alberton, 2001);

(iii) podem ocorrer, no entanto, com verbos inergativos e transitivos, como defendido por Votre \& Naro (1999) e atestado por Pilati (2002) e por Scherre, Naro \& Cardoso (2007):

(3) a. Toma posse o deputado.

b. Tem a palavra a Senadora Heloisa Helena.

c. Merece destaque a nova seção deste jornal.

[Pilati, 2002]

(4) Só valem as garotas.

[Scherre, Naro \& Cardoso, 2007]

Pilati (2006) - que segue a análise descritiva de Pinto (1997) para o italiano propõe que as orações com ordem VS do PB: a) são tipos de inversão locativa e b) apresentam um elemento de natureza locativa, em posição pré-verbal (se nulo, identificado como um pro $_{\text {LOC }}$ ). Segundo a autora, é por esse motivo que tais orações recebem interpretação dêitica, como representado pelo contraste abaixo (dados extraídos de Pilati 2006, p. 199):

(5) a. A Mary chegou. (em algum outro lugar)

b. Chegou a Mary. (nesse momento / aqui / nesse lugar)

[Pilati, 2006] 
Diante desse cenário de ocorrência conjunta de ordem VS e de inversões locativas no PB atual, indaga-se: (i) no português do centro-oeste brasileiro no século XIX já havia inversões locativas? (ii) qual a natureza dos elementos $(\mathrm{X})$ que precediam a estrutura VS? e (iii) a ordem VS, como amplamente defendido na literatura, mantém estreita e direta relação com o parâmetro pro-drop?

Para tentar responder todas as perguntas acima, dividiu-se esta dissertação em três capítulos.

No capítulo 1, será apresentada a evolução do modelo teórico no qual esta dissertação está inserida, qual seja o modelo de princípios e parâmetros da Teoria gerativa. Após analisar o desenvolvimento desse modelo teórico, serão expostos os conceitos do Princípio de Projeção Estendida (conhecido amplamente na literatura pela abreviatura EPP) e do Parâmetro pro-drop, os quais, segundo estudos, estão diretamente relacionados à ordem VS. Para aprofundar o estudo sobre o fenômeno da ordem VS, particularmente no português brasileiro (PB), serão apresentadas ainda no capítulo algumas propostas presentes na literatura. A primeira proposta apresentada será a de Berlinck (1989), funcionalista. Em seguida, serão apresentadas as propostas de Nascimento (1984), de Kato \& Tarallo (1987) e de Kato \& Tarallo (1993), gerativistas.

No capítulo 2, por sua vez, serão apresentadas as principais características das inversões locativas, especialmente no português brasileiro (PB). A fim de subsidiar o estudo, primeiramente serão apresentadas as considerações de Levin \& Rappaport (1995) a respeito do assunto. Em seguida, serão apresentadas, uma a uma, as propostas de Pilati (2002), de Pilati (2006), de Corr (2012) e de Gravina (2014).

No capítulo 3, por fim, serão apresentados os resultados das análises quantitativas efetuadas no corpus escrito do Jornal Matutina Meyapontense sobre as orações na ordem (X)VS, com X manifesto ou nulo. Inicialmente, serão apresentadas informações sobre a constituição da língua no centro-oeste brasileiro até o século XIX. Em seguida, serão apresentados os detalhes sobre o corpus deste trabalho, juntamente com a metodologia utilizada nos dados obtidos. Após essa abordagem, serão apresentadas as análises quantitativas efetuadas no corpus obtido. 


\section{CAPÍTULO 1}

\section{A TEORIA GERATIVA E A ORDEM VS NO PORTUGUÊS BRASILEIRO}

\subsection{Introdução}

O presente capítulo tem por objetivo apresentar a evolução do modelo teórico no qual esta dissertação está inserida, qual seja o modelo de princípios e parâmetros da Teoria gerativa. Após analisar o desenvolvimento desse modelo teórico, serão expostos os conceitos do Princípio de Projeção Estendida (conhecido amplamente na literatura pela abreviatura $E P P)$ e do Parâmetro pro-drop, os quais, segundo estudos, estão diretamente relacionados à ordem verbo-sujeito (VS).

Para aprofundar o estudo sobre o fenômeno da ordem VS, particularmente no português brasileiro (PB), serão apresentadas neste capítulo algumas propostas presentes na literatura. A primeira proposta apresentada será a de Berlinck (1989), funcionalista. Em seguida, serão apresentadas as propostas de Nascimento (1984), de Kato \& Tarallo (1987) e de Kato \& Tarallo (1993), gerativistas.

\subsection{Teoria gerativa}

A teoria gerativa surge no final da década de 1950 sintetizando, de forma conjunta e inédita, os pressupostos filosóficos anteriores. Essa nova corrente que surgia, desenvolvida pelo norte americano Noam Chomsky e por linguistas do Massachusetts Institute of Technology, também procurava solucionar os problemas dos modelos vigentes à época - os do estruturalismo, na Linguística, e os do behaviorismo, na Psicologia.

Segundo Chomsky (1965), os modelos estruturalista e behaviorista utilizavam uma gramática de listas, elaborada a partir de um corpus finito de frases de uma língua, e, portanto, incompleto. $\mathrm{O}$ fato de o modelo distribucional da linguística estruturalista descrever apenas frases já realizadas impossibilitava, de acordo com o precursor da teoria gerativa, a explicação de um grande número de dados linguísticos, como, por exemplo, a ambiguidade dos constituintes descontínuos. 
Para explicar a criação de enunciados, Chomsky (1965) preconiza uma teoria capaz de descrever e explicar os fatos conhecidos, e predizer fatos ainda não observados. Em outras palavras, Chomsky (1965) define uma teoria em que há a internalização do conceito de linguagem e a produção e a compreensão da linguagem verbal pelo ser humano sem a necessidade de aprendizado prévio.

\subsection{Faculdade da linguagem}

O conhecimento inato sobre a linguagem é o objeto central de estudo da teoria gerativa. Enquanto outras correntes buscavam compreender como as línguas se organizavam, observando apenas os dados linguísticos já produzidos pelo indivíduo, a teoria gerativa sempre esteve interessada em investigar a capacidade do ser humano em permitir a geração desses dados. É nesse contexto que surge o conceito de faculdade da linguagem.

A faculdade da linguagem, segundo Noam Chomsky, é uma espécie de órgão mental que contém a capacidade do ser humano de, com recursos finitos e sem aprendizado prévio específico, gerar infinitas frases sintaticamente bem construídas. De acordo com Chomsky (1997):

\footnotetext{
A faculdade da linguagem pode razoavelmente ser considerada como 'um órgão linguístico' no mesmo sentido em que na ciência se fala, como órgãos do corpo, em sistema visual ou sistema imunológico ou sistema circulatório. Compreendido deste modo, um órgão não é alguma coisa que possa ser removida do corpo deixando intacto todo o resto. Um órgão é um subsistema que é parte de uma estrutura mais complexa. Nós temos a esperança de compreender a complexidade do todo em sua plenitude através da investigação das partes que têm características distintivas, e das interações entre elas. Do mesmo modo procede o estudo da faculdade da linguagem. (CHOMSKY, 1997, p. 50)
}

O comportamento linguístico do indivíduo, compreendido como a capacidade humana de falar e de entender uma língua, é resultado, portanto, da faculdade da linguagem. Esse dispositivo inato, segundo Chomsky, está associado à biologia do cérebro/mente da espécie humana e é destinado a constituir a competência linguística de um falante.

A faculdade da linguagem da criança, quando exposta a dados linguísticos de entrada (input), passa de um estado inicial $\left(\mathrm{E}_{0}\right)$ para um estado final $\left(\mathrm{E}_{\mathrm{N}}\right)$, relativamente estável. Nesse estado final verifica-se uma gramática (Língua-I) muito semelhante à de um adulto de sua comunidade linguística, idealmente concebida como homogênea (Chomsky, 1986).

Noam Chomsky argumenta que se a capacidade de falar uma ou mais línguas decorresse apenas do ambiente externo ao indivíduo, como pensavam os behavioristas, um 
chipanzé, após algum tempo de convívio com os seres humanos, seria capaz de falar. Em defesa da faculdade da linguagem, Chomsky argumenta ainda que crianças mais ou menos numa mesma faixa etária são capazes de formular e produzir estruturas sintáticas nunca antes ouvidas por elas. Por fim, o precursor da teoria gerativa enfatiza que as crianças que estão adquirindo a linguagem verbal são capazes de solucionar questões bastante complexas em termos linguísticos, mesmo sem haver interferência precisa e específica dos pais ou de quem as rodeia.

No âmbito do gerativismo, as línguas deixaram, portanto, de ser interpretadas como um comportamento socialmente condicionado e passaram a ser analisadas como uma faculdade mental natural. A mente humana passou a ser, então, o ambiente da linguagem.

Naturalmente, apenas postular a existência da faculdade da linguagem como um dispositivo inato que permite o desenvolvimento de uma competência linguística não é capaz de resolver todos os problemas linguísticos existentes. Torna-se necessário ainda descrever exatamente como a faculdade da linguagem funciona e como é possível que ela seja geneticamente determinada se as línguas do mundo parecem tão diferentes entre si. Nesse sentido, as principais questões que a teoria gerativa busca responder são as seguintes:

(i) O que há em comum entre todas as línguas humanas e de que maneira elas diferem entre si?

(ii) Em que consiste o conhecimento que um indivíduo possui quando é capaz de falar e compreender uma língua?

(iii) Como o indivíduo adquire esse conhecimento?

(iv) De que maneira esse conhecimento é posto em uso pelo indivíduo?

Para responder perguntas como essas, a teoria gerativa analisa a linguagem humana de uma forma matemática e abstrata (formal) e se aproxima da linha interdisciplinar de estudos da mente humana conhecida como Ciências Cognitivas. A maneira pela qual tais perguntas vêm sendo respondidas constitui o modelo teórico do gerativismo.

\subsection{O sistema de regras da gramática}

O primeiro modelo teórico gerativista, denominado de Gramática Transformacional, foi desenvolvido e reformulado diversas vezes durante as décadas de 60 e 70. De acordo com Lobato (1986), os objetivos dessa fase do gerativismo consistiam em 
descrever como os constituintes das sentenças eram formados e como esses constituintes transformavam-se em outros, por meio da aplicação de regras.

Os gerativistas precursores desse primeiro modelo teórico perceberam que as infinitas sentenças de uma língua eram constituídas a partir da aplicação de um sistema finito de regras - o qual transformava, por exemplo, uma sentença declarativa em uma sentença interrogativa. Segundo Lobato (1986), esse sistema de regras era precisamente o que se assumia como o conhecimento linguístico existente na mente do falante de uma língua, o qual deveria ser descrito e explanado pelo linguista gerativista.

Esse modelo inicial pode ser exemplificado a partir da sentença "O menino fechou a porta". A constituição dessa sentença (S) ocorre pela relação estrutural entre o sintagma nominal (SN) "o menino" e o sintagma verbal (SV) "fechou a porta". O SN é formado pelo determinante (DET) "o" e pelo nome (N) "menino", e o SV, por sua vez, é constituído pelo verbo (V) "fechou" e pelo outro SN "a porta", o qual se forma também por uma relação entre DET e N, no caso "a" e "porta" respectivamente. Os gerativistas representam essa sentença $(\mathrm{S})$, assim como outras estruturas sintagmáticas, por meio de diagramas arbóreos (também denominados de árvores). Veja a seguir uma representação, logo no início da teoria, dos níveis dos constituintes da sentença $O$ menino fechou a porta:

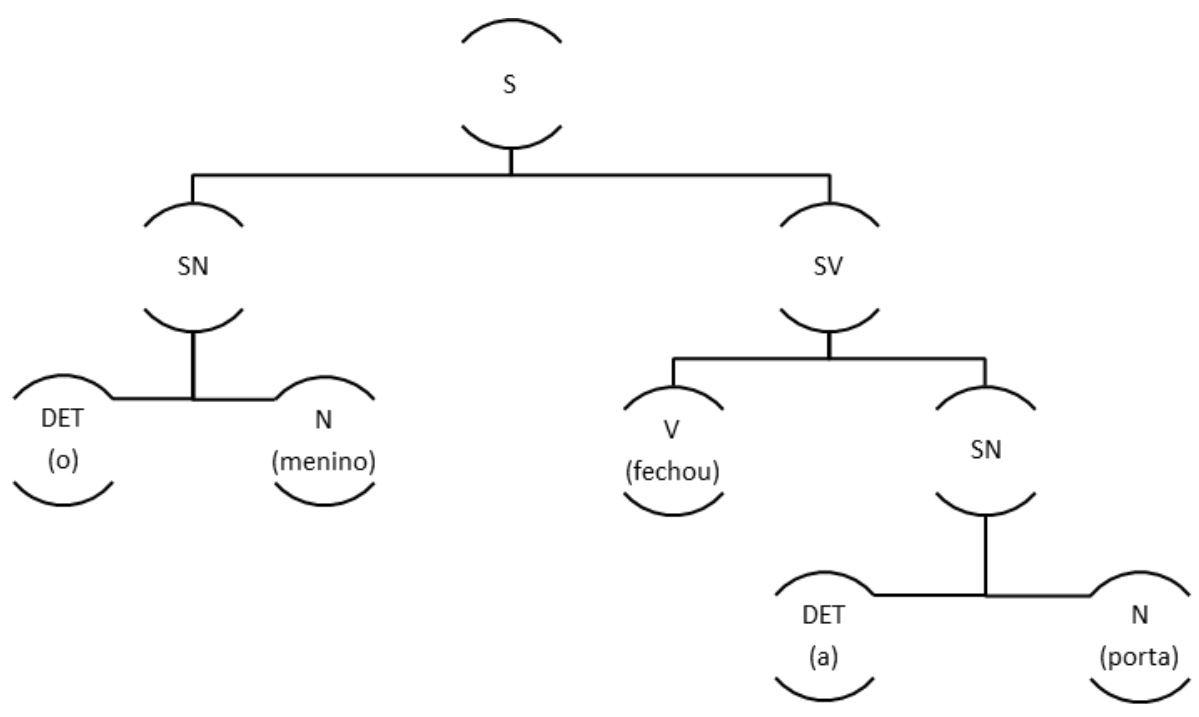

Essas regras de composição sintagmática explicam como uma estrutura simples como essa ( $O$ menino fechou a porta) é gerada, mas não são suficientes para explicar como uma outra estrutura relacionada, como a voz passiva, seria formada a partir da estrutura de 
base, no caso, a voz ativa. Lobato (1986) explica que - para solucionar essa relação entre estruturas diferentes, mas conjugadas - os gerativistas formularam regras transformacionais.

De acordo com Lobato (1986), uma transformação, naturalmente, forma uma estrutura a partir de uma sentença previamente existente. A estrutura originariamente formada é chamada de Estrutura Profunda e a estrutura dela derivada chama-se Estrutura Superficial. A voz ativa, nesse sentido, é interpretada como a estrutura profunda, sobre a qual são utilizadas as regras transformacionais que geram a voz passiva, a estrutura superficial.

Na década de 90, no entanto, a ideia da transformação de uma estrutura profunda numa estrutura superficial foi abandonada em favor de uma visão que não mais representava estruturas, e sim as derivava - revelando os passos pelos quais uma estrutura é formada (derivada), sem que ela tenha de ser comparada com uma outra estrutura independente.

\subsection{Gramática Universal: princípios e parâmetros}

A hipótese da Gramática Universal representa um refinamento da noção da faculdade da linguagem, defendida pelo gerativismo desde o seu surgimento. Como visto nas seções anteriores, a faculdade da linguagem é o dispositivo inato presente em todos os seres humanos, como herança biológica, que fornece ao indivíduo um algoritmo, isto é, um conjunto de instruções que torna o ser humano apto para adquirir e desenvolver a gramática de uma língua. Esse algoritmo, segundo Chomsky (1980), é a Gramática Universal.

Os estudiosos gerativistas, a fim de descrever a natureza e o funcionamento da Gramática Universal, formularam uma teoria chamada de Princípios e Parâmetros. Essa teoria possui pelo menos duas fases: a fase da Teoria da Regência e da Ligação, a qual perdurou por toda a década de 80, e o Programa Minimalista, em desenvolvimento desde o início da década de 90 até os dias atuais.

As pesquisas da teoria de Princípios e Parâmetros, segundo Kenedy (2008), foram e são desenvolvidas essencialmente na área da sintaxe, porque é exatamente nas estruturas sintáticas que mais evidentemente se percebem as maiores semelhanças entre todas as línguas do mundo, mesmo entre aquelas que não possuem parentesco, o que facilita o estudo da Gramática Universal. Para exemplificar essas semelhanças, pode-se apontar que todas as línguas do mundo possuem estruturas - como orações adjetivas e orações interrogativas - e funções sintáticas - como sujeito, predicado e complemento. ${ }^{1}$

1 Na teoria gerativa, na fase sem transformações, expressões como "orações adjetivas" e "orações interrogativas" não eram empregadas com a acepção em que hoje são utilizadas. 
A possibilidade de estudar a sintaxe em dissociação dos demais componentes da gramática (léxico, fonologia, morfologia, semântica) é resultado de um conceito fundamental do gerativismo, o de gramática modular. De acordo com esse conceito, os componentes da gramática devem ser analisados como módulos autônomos, independentes entre si, de modo que não sofram influência direta dos outros módulos.

Apesar desse conceito de gramática modular, cabe ressaltar que, naturalmente, existem pontos de interseção entre os módulos da gramática. De acordo com Kenedy (2008), a sintaxe cria sintagmas e sentenças a partir das palavras do léxico, e o produto final da sintaxe (a sentença) deve receber uma leitura fonológica, na Forma Fonética, e também uma interpretação semântica básica, na Forma Lógica.

O elemento central da gramática, como visto, está associado aos mecanismos sintáticos da língua. A sintaxe extrai do léxico as palavras com que construirá, segundo suas próprias regras, estruturas como sintagmas e sentenças, as quais são encaminhadas para a pronúncia, no módulo fonológico, e para a interpretação formal, no módulo semântico. Nesse modo de compreender o funcionamento da gramática, a morfologia é interpretada como parte do léxico, já que é responsável pela estrutura interna da palavra, e também como parte da fonologia, uma vez que está associada às alterações mórficas fonologicamente condicionadas.

O Programa Minimalista - baseado em critérios de naturalidade, parcimônia, simplicidade, elegância e adequações descritiva e explanatória - pressupõe a arquitetura de Princípios e Parâmetros, segundo Hornstein et al. (2005), como condição de fronteira para qualquer teoria gramatical efetiva. Nesse contexto, entende-se por Princípio as propriedades gramaticais que são válidas para todas as línguas naturais, ao passo que Parâmetro deve ser compreendido como valores binários fixados durante o processo de aquisição de uma determinada língua. Cabe destacar que, no Programa Minimalista, os princípios deixam de ser especificamente linguísticos, de Gramática Universal, e passam a ser reduzidos a um princípio geral de economia e a um princípio que garante o estabelecimento de relações de interface da língua com sistemas de desempenho.

\subsection{Princípio de Projeção Estendida}

Um dos princípios mais importantes do modelo de Princípios e Parâmetros foi o Princípio de Projeção, desenvolvido por Chomsky (1981). De acordo com esse princípio, a estrutura profunda (Estrutura-D) era projetada a partir do léxico, o que resultava em observância às propriedades temáticas e às propriedades de subcategorização dos itens lexicais. O Princípio de Projeção determinava, ainda, que apenas argumentos selecionados por 
um núcleo lexical poderiam ser projetados na sintaxe. Essa última afirmativa criou, porém, um impasse em línguas como o inglês e o francês:
(1) Chove.
(2) a. Il pleut.
b. *Pleut.

(3) a. It rains.
b. * Rains.

As sentenças (1), (2) e (3) trazem, respectivamente, exemplos do português, do francês e do inglês. Ao contrário da construção (1), as sentenças (2a) e (3a) trazem, respectivamente, os pronomes il e it antecedendo o verbo. Esses pronomes, no entanto, são expletivos, e, portanto, não poderiam ser selecionados por um núcleo lexical. ${ }^{2}$

Para resolver essa questão, Chomsky (1982) reformula o Princípio de Projeção e cria um novo princípio, o Princípio de Projeção Estendida. De acordo com esse novo princípio: (i) as estruturas sintáticas seriam a projeção da estrutura temática e de subcategorizações dos predicadores e (ii) a posição de sujeito se tornaria obrigatória.

A exigência da obrigatoriedade de sujeito em todas as línguas pode ser verificada nos exemplos a seguir, que trazem sentenças do português, do francês e do inglês:

(4) Chove.

(5) a. Il pleut.

b. *Pleut.

c. *__ Pleut.

(6) a. It rains.

b. *Rains.

c. *__ Rains.

A sentença (4), referente ao português, revela que a posição de sujeito é preenchida por um pronome nulo (pro), que, embora não possua uma matriz fonológica,

2 Pronomes expletivos são aqueles que não possuem conteúdo semântico, mas que, mesmo assim, são responsáveis por preencher alguma posição sintática. 
contém traços de pessoa e número. As sentenças (5) e (6), por sua vez, evidenciam que a efetivação fonética de $i l$, em (5a), e de $i t$, em (6a), é obrigatória, o que implica dizer que a posição de sujeito no inglês e no francês existe independentemente da seleção de um argumento externo pelos verbos. De uma forma geral, as sentenças (4), (5) e (6) exemplificam que todas as línguas possuem sujeitos, sejam eles nulos ou plenos. ${ }^{3}$

Como visto na seção anterior, no Programa Minimalista os princípios deixam de ser especificamente linguísticos, de Gramática Universal, e passam a ser reduzidos a um princípio geral de economia e a um princípio que garante o estabelecimento de relações de interface da língua com sistemas de desempenho. Nesse programa, o Princípio de Projeção Estendida, portanto, é reconfigurado.

No Programa Minimalista, a obrigatoriedade do sujeito é codificada como um traço do Princípio de Projeção Estendida (traço EPP) em T, que disponibiliza a posição de especificador a ser preenchida. ${ }^{4}$ Em outras palavras, $\mathrm{T}$ é uma categoria funcional que apresenta traços não-interpretáveis que atuam como sonda. O traço EPP determina se a sonda oferece uma posição de especificador para receber o elemento movido. Dessa forma, o especificador do verbo (Spec, V) se move para a posição de especificador de T (Spec, T), que é a posição de sujeito (Chomsky, 1999).

Apesar dessa nova visão do Programa Minimalista, a ideia central do Princípio de Projeção Estendida continua presente. Isso porque em todas as línguas do mundo ainda se percebe a obrigatoriedade da presença de sujeito.

\subsection{Parâmetro pro-drop}

Parâmetros são conjuntos de propriedades do sistema gramatical que têm o seu valor fixado a partir da informação positiva obtida por meio do input disponível. A realização ou a não-realização de determinada categoria estabelece o parâmetro em uma das duas posições possíveis: positiva (+) ou negativa (-). De acordo com Chomsky, 1981, a realização do sujeito, bem como a sua inversão em relação ao verbo, está diretamente relacionada a esse parâmetro.

Chomsky (1981) aponta cinco propriedades que, juntas, formam um conjunto essencial para a marcação positiva do parâmetro pro-drop: (i) sujeito nulo; (ii) inversão livre do sujeito; (iii) movimento longo do sujeito, a partir da ilha $Q u-$; (iv) pronome resumptivo

\footnotetext{
3 O fato de algumas línguas preencherem a posição de sujeito por meio de pro e de outras línguas preencherem essa posição de forma plena não diz respeito a essa questão principiológica ora em estudo, já que essa situação remete a uma questão paramétrica.

4 A sigla EPP é decorrente da expressão do inglês Extended Projection Principle.
} 
vazio em orações encaixadas; e (v) aparente violação do filtro trat-trace. ${ }^{5}$ Os exemplos (7) a (11), a seguir, extraídos de Rizzi (1982), revelam os contrastes entre uma língua [+ pro-drop] e uma língua [-pro-drop]:

\section{- Sujeito nulo:}

(7) a. Ha telefonato.

b. *Has phoned.

(Telefonou.)

- Inversão livre do sujeito:

(8) a. Ha telefonato Gianni.

b. *Phoned John.

(Telefonou João.)

- Movimento longo do sujeito, a partir da ilha $Q u-:$

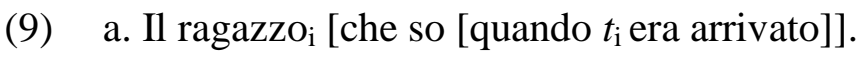

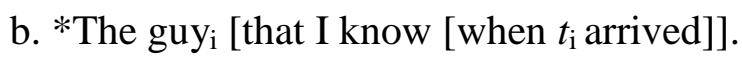

(O rapaz que sei quando chegou.)

\section{- Pronome resumptivo vazio em orações encaixadas:}

(10) a. Gianni $\mathrm{i}_{\mathrm{i}}$ ha detto [che $t_{\mathrm{i}}$ ha telefonato].

b. ${ }^{*} \mathrm{John}_{\mathrm{i}}$ said [that has $t_{\mathrm{i}}$ phoned].

(João disse que telefonou.)

- Aparente violação do filtro trat-trace:

(11) a. $\mathrm{Chi}_{\mathrm{i}}$ [Maria ha pensato [che $t_{\mathrm{i}}$ avia arrivato]?

b. *Who ${ }_{\mathrm{i}}$ [Mary thought [that $t_{\mathrm{i}}$ has arrived]?

(Quem Maria pensou que chegou?)

[Rizzi, 1982, p. 121]

Os exemplos (7) a (11) - que ilustram, respectivamente, as cinco propriedades essenciais para a marcação positiva do parâmetro pro-drop - revelam os contrastes entre o italiano, ilustrados nas sentenças (a), e o inglês, ilustrados nas sentenças (b). As sentenças (a)

5 O filtro that-trace, proposto por Chomsky \& Lasnik (1977), impede o movimento do sujeito por sobre um complementador lexicalmente preenchido. 
atendem todas as cinco propriedades para a marcação positiva do parâmetro pro-drop, motivo pelo qual se pode afirmar que o italiano é uma língua [+ pro-drop]. O inglês, ao contrário, é [-pro-drop], já que não atende ao conjunto das cinco propriedades elencadas anteriormente.

Em relação ao português brasileiro (PB), estudos como o de Duarte (1995) mostram que a língua vem apresentando um comportamento diverso em relação às línguas que possuem as cinco propriedades da marcação positiva do parâmetro pro-drop. As sentenças (12) a (16) ilustram o comportamento dessa variedade no PB para cada propriedade:

- Sujeito nulo:

(12) a. (Eu) encontrei o livro.

- Inversão livre do sujeito:

(13) a. *Comeu o Giovani.

- Movimento longo do sujeito, a partir da ilha $Q u$-:

(14) $\mathrm{O}_{\text {homem }}$ que eu sei que livro $\mathrm{k}$ i leu

- Pronome resumptivo vazio em orações encaixadas:

(15) O João disse que i telefonou.

O João disse que ele $_{\mathrm{i}}$ telefonou...

- Aparente violação do filtro trat-trace:

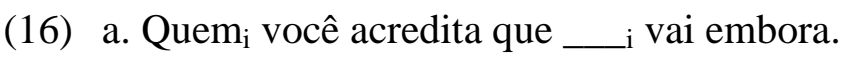

b. *Quem ${ }_{i}$ você acredita que ele ${ }_{i}$ vai embora.

Duarte (1995) afirma que, no tocante aos sujeitos referenciais, o PB mostra grande preferência, nas três pessoas gramaticais, pelo preenchimento da posição de sujeito. Esse preenchimento ocorre mesmo nos casos em que a flexão poderia garantir a interpretação do sujeito nulo - como é o caso da primeira pessoa, observado no exemplo (12).

Em relação à inversão livre, o PB parece também ter perdido essa propriedade para verbos transitivos (cf. Lira, 1986; Berlinck, 1989; Coelho, 2000), em que se verifica a preferência pela ordem SVO. ${ }^{6}$ Essa observação pode ser verificada no exemplo ilustrado em (13).

6 O termo SVO corresponde à ordem sujeito-verbo-objeto. 
As sentenças (14) e (15), por sua vez, mostram que, no PB, o movimento longo do sujeito, a partir da ilha $Q u-$, e a realização de pronomes resumptivos em orações encaixadas são a preferência. Essa evidência parece representar uma consequência da remarcação do parâmetro pro-drop.

Em resumo, como se pode atestar pelos exemplos acima, o PB ainda possui algumas propriedades relacionadas ao parâmetro do sujeito nulo, mas não apresenta um comportamento uniforme, como o italiano, por exemplo. Diferentemente do italiano e do inglês - línguas prototípicas [+ pro-drop] e [-pro-drop], respectivamente - , o português brasileiro vem marcando o parâmetro pro-drop de forma assistemática. A realização do sujeito nulo no PB, por exemplo, não é a escolha preferencial. No Brasil, segundo Duarte (1995), o sujeito vem sendo recorrentemente realizado foneticamente, o que aponta para a perda de uma propriedade paramétrica que já ocorreu na Língua-I e já se revela completamente nos dados de Língua-E.

Há inclusive pesquisadores, como Marins (2009), que defendem que já é possível encontrar no PB evidências de quantificadores e expressões quantificadas ligadas a pronomes expressos - o que pode ser verificado no exemplo (17):

(17) a. Cada um i $_{\text {podia fazer as perguntas que ele }}$ queria. (Rádio CBN)

b. Qualquer americano você acha que ele $_{i}$ vota no Obama? (Fala espontânea)

[Marins, 2009, p. 23]

Como o objetivo desta dissertação é analisar o fenômeno da inversão locativa no português do centro-oeste brasileiro no século XIX, não será discutido o estatuto do pro. ${ }^{7}$ Passar-se-á, então, à próxima seção, em que serão apresentadas algumas pesquisas sobre ordem verbo-sujeito, a fim de, no próximo capítulo, analisar os estudos sobre inversão locativa.

\subsection{A ordem VS no português brasileiro}

A ordem verbo-sujeito (VS), de acordo com Menuzzi (2004), tem sido objeto de análise pela literatura linguística nos últimos 20 anos devido ao fato de: (i) a ordem VS no português brasileiro $(\mathrm{PB})$ ter uma frequência menor quando comparada à ordem VS no português europeu (PE) ou mesmo na variante culta brasileira (cf. Thomas, 1969; Lira, 1982;

7 Para trabalhos que discutem o estatuto do pro ver Figueiredo Silva (1996), Negrão (2000), Rodrigues (2004), Modesto (2008) e Naves \& Pilati (2013). 
Pontes, 1986) e (ii) o PB ser a língua inovadora entre as línguas românicas em relação à ordem VS. A seguir, um trecho extraído de Menuzzi (2004):

(...) até o século XIX, o PB teria mantido um padrão de ordem semelhante ao do PE e das demais línguas românicas, em que a possibilidade de inversão entre verbo e sujeito seria relativamente livre; a partir de então, mudanças na organização da língua teriam resultado em severas restrições à possibilidade de se usar a ordem VS (cf. Kato \& Tarallo 1987, Berlinck 1989, Duarte 1996, Figueiredo Silva 1996, entre outros). (MENUZZI, 2004, p. 350)

Menuzzi (2004) expõe que o comportamento particular do PB em relação às demais línguas românicas evidencia pelo menos três questões gerais de análise linguística. Segundo o autor, a primeira, descritiva, seria analisar a diferença da ordem VS no PB e nas demais línguas românicas (especificamente no PE); a segunda, teórica, seria verificar se existe alguma fonte particular para essa diferença; e a terceira, histórica, seria buscar o porquê e o procedimento de surgimento dessa diferença.

No âmbito da perspectiva gerativista, Menuzzi (2004) discorre que a maioria dos trabalhos sobre a ordem VS no PB (Nascimento, 1984; Kato \& Tarallo, 1987; Nicolau, 1995; Figueiredo Silva, 1996) baseia-se na hipótese de que os sujeitos somente podem produtivamente ser pospostos ao verbo se puderem, por uma razão ou outra, ser estruturalmente analisados como objetos. Segundo o autor, essa hipótese, que apresenta pontos originários do trabalho de Perlmutter (1976), tornou-se ainda mais atraente no quadro teórico da sintaxe gerativa após a afirmação de que o PB estaria se tornando uma língua não pro-drop, isto é, uma língua de sujeito obrigatório.

As várias propostas dos estudiosos apresentados por Menuzzi (2004), bem como as de outros pesquisadores, contribuíram com aspectos importantes relacionados a propriedades e características sintáticas e/ou semânticas das configurações que licenciam a ordem verbo-sujeito no português brasileiro. Algumas dessas contribuições serão apresentadas nas subseções a seguir, sendo apresentado, primeiramente, o trabalho funcionalista de Berlinck (1989) e, em seguida, os trabalhos gerativistas, estes na ordem cronológica em que foram desenvolvidos.

\subsubsection{A proposta de Berlinck (1989): o decréscimo da ordem VS, especialmente com verbos transitivos}

Berlinck (1989) inicia seu estudo fazendo uma comparação entre duas afirmações a respeito do fenômeno da ordem no português do Brasil. 
A seguir, apresentam-se os dois trechos comparados por Berlinck (1989):

(...) as construções direta e invertida são ambas naturais, porque ambas, quando lhes é possível, se conformam à ordem com que nosso espírito concebe as coisas. (SOARES BARBOSA, 1803, p. 296)

Parece claro que a língua portuguesa hoje é predominantemente SV. A ordem VS se mantém em casos especiais, sobretudo em orações marcadas em relação à oração declarativa, afirmativa, neutra. (EUNICE PONTES, 1987, p. 163)

[Berlinck, 1989, pp. 95-96]

A partir da comparação entre os trechos anteriores, Berlinck (1989) chega a duas conclusões:

(i) O fato de Soares Barbosa tratar em igualdade construções SV e VS sugere que essas duas possibilidades eram igualmente comuns naquele momento. Já a afirmação de Eunice Pontes, por sua vez, leva a pensar que VS teve seu espaço de atuação limitado, a ponto de ficar restrita a alguns contextos bem marcados, e que se tornou pouco produtiva.

(ii) Segundo Soares Barbosa, as ordens SV e VS era definida subjetivamente. Dois séculos depois, a afirmação de Eunice Pontes indica que o fenômeno da ordem estaria sendo determinado por fatores de natureza estritamente gramatical. (BERLINCK, 1989, p. 95)

Diante dessas duas conclusões, Berlinck (1989) formula, então, a hipótese de que houve uma alteração no fenômeno da ordem. Para investigar esse fenômeno e investigar essa hipótese, a autora, em um período em que o acesso ao registro falado era impossível, compôs três corpora, correspondentes a momentos históricos distintos, que foram analisados complementarmente nos planos sincrônico e diacrônico, sob a Teoria da Variação e Mudança Linguísticas.

A análise quantitativa dos dados foi apresentada por Berlinck (1989) em forma de tabelas, as quais são expostas nesta dissertação na tabela 1, a seguir:

Tabela 1 - Frequência de V SN segundo os corpora analisado

\begin{tabular}{ccc}
\hline Corpus & \% & N \\
\hline Século XVIII (1750) & 42 & $203 / 486$ \\
Século XIX (1850) & 31 & $144 / 469$ \\
Século XX (1987) & 21 & $263 / 1262$ \\
\hline
\end{tabular}

Fonte: Berlinck (1989, p. 97) 
Os dados da tabela 1 indicam: (i) uma diminuição da ordem VS à medida que se passa de um momento a outro, em direção ao corpus sincrônico (1987); (ii) um aumento da frequência de SV e (iii) um enrijecimento da ordem SV, que começa a dominar, aos poucos, os contextos antes divididos com VS.

Tabela 2 - Princípios mais fortes, por ordem de importância, para cada momento

\begin{tabular}{ccc}
\hline Século XVIII & Século XIX & Século XX \\
\hline 1. Status informacional & 1. Tipo de predicador & 1. Transitividade do \\
do SN & & verbo \\
2. Realização do SN & 2. Realização do SN & 2. Realização do SN \\
3. Distinção aspectual & 3. Estatuto da oração & 3. Animacidade do SN \\
operação/resultado & & \\
4. Tipo de predicador & & 4. Distinção aspectual \\
& & operação/resultado \\
& & 5. Concordância verbal \\
\hline Fonte: Berlinck $(1989$, p. 97) & &
\end{tabular}

Os dados da tabela 2 indicam que cada corpus apresentava uma estruturação própria, em que nem sempre estavam presentes os mesmos fatores dos demais corpora. E mesmo quando havia coincidência, as relações de força existentes entre os fatores era de todo particular a cada momento. Havia uma re-hierarquização dos fatores. Observa-se, assim, que houve uma passagem de uma orientação mais funcional para uma formal.

Tabela 3 - Frequência de V SN a partir do cruzamento de status informacional do SN e transitividade do verbo, no corpus do século XVIII

\begin{tabular}{|c|c|c|c|c|}
\hline $\begin{array}{c}\text { Status } \\
\text { informacional } \\
\text { Realização do SN }\end{array}$ & $\begin{array}{l}\text { Novo } \\
(54 \%)\end{array}$ & $\begin{array}{l}\text { Inferível } \\
(43 \%)\end{array}$ & $\begin{array}{c}\text { Dado em sentença não- } \\
\text { imed. anterior } \\
(26 \%)\end{array}$ & $\begin{array}{c}\text { Dado em sentença } \\
\text { imed. anterior } \\
(18 \%)\end{array}$ \\
\hline $\begin{array}{c}\text { Intransitivo não- } \\
\text { existencial } \\
(59 \%)\end{array}$ & $70 \%$ & $62 \%$ & - & - \\
\hline $\begin{array}{c}\text { Verbo de ligação } \\
\qquad(47 \%)\end{array}$ & $66 \%$ & $44 \%$ & $20 \%$ & - \\
\hline
\end{tabular}




\begin{tabular}{ccccc}
\hline $\begin{array}{c}\text { Expressão fixa } \\
(\mathbf{4 7 \% )})\end{array}$ & $65 \%$ & - & - & - \\
$\begin{array}{c}\text { Transitivo indireto } \\
(34 \%)\end{array}$ & $40 \%$ & $31 \%$ & $35 \%$ & - \\
$\begin{array}{c}\text { Transitivo direto } \\
(34 \%)\end{array}$ & $35 \%$ & $37 \%$ & $32 \%$ & $29 \%$ \\
$\begin{array}{c}\text { Bitransitivo } \\
(30 \%)\end{array}$ & $38 \%$ & - & $0 \%$ & - \\
\hline
\end{tabular}

Fonte: Berlinck (1989, p. 99)

Tabela 4 - Frequência de V SN a partir do cruzamento de status informacional do SN e transitividade do verbo, no corpus do século XIX

\begin{tabular}{|c|c|c|c|c|}
\hline $\begin{array}{c}\text { Status } \\
\text { informacional } \\
\text { Realização do SN }\end{array}$ & $\begin{array}{l}\text { Novo } \\
(36 \%)\end{array}$ & $\begin{array}{c}\text { Inferível } \\
(\mathbf{3 0 \%})\end{array}$ & $\begin{array}{c}\text { Dado em sentença não- } \\
\text { imed. anterior } \\
(25 \%)\end{array}$ & $\begin{array}{c}\text { Dado em sentença } \\
\text { imed. anterior } \\
(\mathbf{1 7 \%})\end{array}$ \\
\hline $\begin{array}{c}\text { Intransitivo não- } \\
\text { existencial } \\
(47 \%)\end{array}$ & $57 \%$ & $36 \%$ & - & - \\
\hline $\begin{array}{c}\text { Verbo de ligação } \\
(30 \%)\end{array}$ & $38 \%$ & $29 \%$ & $19 \%$ & - \\
\hline $\begin{array}{c}\text { Expressão fixa } \\
(\mathbf{2 8 \%})\end{array}$ & $50 \%$ & $0 \%$ & - & - \\
\hline $\begin{array}{l}\text { Transitivo indireto } \\
\qquad(36 \%)\end{array}$ & $33 \%$ & $48 \%$ & $30 \%$ & - \\
\hline $\begin{array}{l}\text { Transitivo direto } \\
\qquad(21 \%)\end{array}$ & $20 \%$ & $21 \%$ & $24 \%$ & - \\
\hline $\begin{array}{c}\text { Bitransitivo } \\
(15 \%)\end{array}$ & $17 \%$ & - & $7 \%$ & - \\
\hline
\end{tabular}

Fonte: Berlinck (1989, p. 100) 
Tabela 5 - Frequência de V SN a partir do cruzamento de status informacional do SN e transitividade do verbo, no corpus sincrônico (século XX)

\begin{tabular}{|c|c|c|c|c|}
\hline $\begin{array}{c}\text { Status } \\
\text { informacional } \\
\text { Realização do SN }\end{array}$ & $\begin{array}{l}\text { Novo } \\
(26 \%)\end{array}$ & $\begin{array}{c}\text { Inferível } \\
(25 \%)\end{array}$ & $\begin{array}{c}\text { Dado em sentença não- } \\
\text { imed. anterior } \\
(17 \%)\end{array}$ & $\begin{array}{c}\text { Dado em sentença } \\
\text { imed. anterior } \\
(9 \%)\end{array}$ \\
\hline $\begin{array}{c}\text { Intransitivo não- } \\
\text { existencial } \\
(46 \%)\end{array}$ & $50 \%$ & $58 \%$ & $37 \%$ & $20 \%$ \\
\hline $\begin{array}{l}\text { Verbo de ligação } \\
\qquad(23 \%)\end{array}$ & $30 \%$ & $24 \%$ & $24 \%$ & $12 \%$ \\
\hline $\begin{array}{c}\text { Expressão fixa } \\
(13 \%)\end{array}$ & $25 \%$ & $16 \%$ & $9 \%$ & $9 \%$ \\
\hline $\begin{array}{c}\text { Transitivo indireto } \\
\qquad(8 \%)\end{array}$ & $13 \%$ & $8 \%$ & $8 \%$ & $0 \%$ \\
\hline $\begin{array}{l}\text { Transitivo direto } \\
\qquad(3 \%)\end{array}$ & $4 \%$ & $4 \%$ & $2 \%$ & $0 \%$ \\
\hline $\begin{array}{c}\text { Bitransitivo } \\
(0 \%)\end{array}$ & - & - & - & - \\
\hline
\end{tabular}

Fonte: Berlinck (1989, p. 101)

As tabelas 3, 4 e 5 revelam o contraste da ordem VS no século XVIII e no século XX. Segundo Berlinck (1989), o fato de os verbos transitivos determinarem mudanças nos resultados de status informacional naquele corpus é extremamente significativo. Isso porque os resultados gerais mostraram que o encaminhamento da diminuição de frequência de VS atingiu antes e com mais intensidade os contextos "mais transitivos", agindo mais brandamente à medida em que os contextos se intransitivizavam.

Ademais, Berlinck (1989) aponta que, em termos funcionais, o grau de probabilidade de ocorrência da ordem VS com um dado verbo está associado ao grau de possível ambiguidade dessa construção numa relação inversamente proporcional: quanto maior é a chance de o SN ser interpretado como uma função que não a de argumento externo (principal) de $\mathrm{V}$, menor é a probabilidade de que ele ocorra em VS, e vice-versa. Por uma decorrência natural desse princípio, verbo-predicadores com mais de um argumento são sempre os mais avessos à ordem VS, porque existe, nesses casos, a possibilidade de que um SN posposto ao qual se deveria atribuir função sujeito seja percebido como objeto. 
Apesar dessa situação, Berlinck (1989) explica que os verbos transitivos apresentam percentuais relativamente altos de VS nos corpora do século XVIII e XIX em oposição aos resultados 'desfavoráveis' observados no corpus sincrônico (século XX). Segundo a autora, o contraste faz crer que os riscos de ambiguidade em construções transitivas na ordem VS cresceram muito nesses intervalos de tempo, restringindo a ocorrência de VS a poucos contextos. Portanto, de acordo com a autora, algum tipo de pressão estrutural deve ter agido no sentido de se operar a reanálise.

Berlinck (1989) conclui que, pela comparação dos três momentos da língua, foi possível caracterizar o caminho percorrido pelo fenômeno da ordem. Segundo a autora, verificou-se que, em cada um dos corpora, a variação apresentava uma estrutura própria e que a passagem de um a outro revelava mudanças nessa organização como causas das modificações percebidas na alternância VS (verbo-sujeito) / SV (sujeito-verbo).

\subsubsection{A proposta de Nascimento (1984): ordem VS como "interpretação de lista" e apenas com verbos inergativos e inacusativos}

O estudo de Nascimento (1984), que examina a questão da posposição do sujeito ao verbo no português brasileiro (PB), defende a hipótese de que não existe inversão livre do sujeito. Para o autor, a ordem VS no PB somente é possível com verbos inergativos (18a) e inacusativos (18b):

(18) a. Viajou um professor de história.

b. Chegou petróleo ontem.

Todas as orações com ordem VS no PB, segundo Nascimento (1984), devem ser consideradas existenciais (ou apresentativas, como prefere denominá-las). Para o autor, as orações apresentativas são aquelas que possuem as seguintes características: (i) expressam afirmação ou negação de existência; (ii) relacionam a noção de existência ao quadro de referência de alguém; (iii) podem geralmente ser expressas em inglês por sentenças com there be.

Ainda de acordo com Nascimento (1984), além das características supracitadas, as orações com ordem VS no PB recebem sempre "interpretação de lista". Segundo o autor, essa configuração ocorre quando há um NP sujeito que, num certo nível de representação, é interpretado como em (19). 
(19) Viajou a moça. (e não o rapaz)

Viajou $x$ e $x \in Z$

$\mathrm{X}=$ moça

$\mathrm{Z}=$ grupo das pessoas susceptíveis de viajar

Nascimento (1984) observa que, numa oração como Viajou a moça, o DP a moça pode ser licenciado nessa posição porque preenche a posição de um elemento de um dado conjunto (o de pessoas com a possibilidade de viajar), presente na mente do falante.

Em relação à estrutura sintática proposta para as orações com ordem VS, Nascimento (1984) defende que sujeitos pós-verbais estão numa posição de objeto, à direita do verbo. Esse verbo, segundo o autor, será sempre ou inacusativo ou inergativo.

\subsubsection{A proposta de Kato \& Tarallo (1987): ordem VS com verbos inacusativos, com verbos não-inacusativos e com sujeitos definidos.}

A mudança paramétrica pela qual o português brasileiro (PB) vem passando, qual seja o de estar deixando de ser uma língua pro-drop para se tornar uma língua de sujeito obrigatório, parece ratificar, segundo Kato \& Tarallo (1987), as restrições impostas pelo PB à ordem VS. Nesse sentido:

E isso parece ser corroborado justamente pelas restrições impostas pelo $\mathrm{PB}$ à ordem VS: a literatura sobre o parâmetro do sujeito nulo enfatiza o fato de que uma das principais propriedades de uma língua de sujeitos obrigatórios é precisamente a de impor severas restrições à ordem VS. (KATO \& TARALLO, 1987, p. 15)

Kato \& Tarallo (1987) apresentam algumas estruturas de ordem VS no PB, em que estão incluídas construções com: (i) verbos inacusativos; (ii) verbos não-inacusativos; e (iii) sujeitos definidos.

Nas estruturas inacusativas, Kato \& Tarallo (1987) defendem que o sujeito invertido ocupa, na verdade, a posição de objeto verbal, e o verdadeiro sujeito gramatical da oração é um pronome expletivo nulo. Essa composição revela-se análoga às estruturas VS encontradas em línguas não pro-drop, como, por exemplo, o inglês e o francês. Kato \& Tarallo (1987) destacam que essa evidência circunstancial poderia ter surgido da evidência atual do PB em evitar a concordância entre verbo e sujeito na ordem VS, como será exposto em (20). 
(20) a. De repente apareceu três cara mal-encarado.

b. Três cara mal-encarado apareceram de repente.

Ainda sobre as estruturas inacusativas, Kato \& Tarallo (1987) expõem que, nessas construções, o sujeito é, por hipótese, um pro expletivo, não correspondendo ao sujeito sintático. Esse pro expletivo em PB, segundo os autores, é possivelmente especificado como $3^{\text {a }}$ pessoa do singular, o que se faz esperar que os verbos em estruturas inacusativas apresentem uniformemente flexão de $3^{\mathrm{a}}$ pessoa do singular independentemente do sujeito, isto é, espera-se a ausência de concordância nestas construções.

Ademais, Kato \& Tarallo (1987) expõem que os verbos inacusativos favorecem sujeitos invertidos indefinidos, já que o NP é indefinido. Por fim, ainda sobre essas construções, os autores apontam que, a respeito da ordem de elementos adverbiais: (i) precedem o verbo advérbios de modalidade, frequência e atitude; (ii) ocorrem entre o verbo e o sujeito invertido advérbios de frequência e modo; e (iii) ocorrem depois do sujeito invertido advérbios de tempo, lugar e modo.

Nas estruturas com verbos intransitivos não-ergativos e com verbos transitivos, a ordem VS apenas seria possível - segundo Kato \& Tarallo (1987) - se o sujeito ocupasse sua posição canônica na sentença e o verbo se deslocasse para uma posição mais alta, movimento esse que poderia ser acionado, por exemplo, pela presença de um elemento -QU. Kato \& Tarallo (1987) apontam, ainda, que, pelo fato de o sujeito ocupar a posição de sujeito sintático da oração, espera-se que haja concordância entre o sujeito invertido e a forma verbal nessas construções.

Além disso, Kato \& Tarallo (1987) expõem que o tipo de verbo das construções com verbos intransitivos não-ergativos e com verbos transitivos favorece sujeitos invertidos definidos, já que o NP é definido. Por fim, ainda sobre essas construções, os autores apontam que, a respeito da ordem de elementos adverbiais: (i) não há elementos adverbiais que precedam o verbo; (ii) ocorrem entre o verbo e o sujeito invertido advérbios de modalidade; e (iii) ocorrem depois do sujeito invertido advérbios de modalidade, atitude, frequência, tempo, lugar e modo.

Nas estruturas de antitópico, Kato \& Tarallo (1987) afirmam que o sujeito invertido seria um afterthought, isto é, um esclarecimento do sujeito sintático, presumivelmente o tópico da sentença. 
De acordo com Kato \& Tarallo (1987):

Sintaticamente, estas estruturas teriam um sujeito pronominal referencial, que em PB se manifestaria normalmente por um pronome pleno e, residualmente, como um pronome nulo pro. Do ponto de vista da superfície, somente este último caso, é claro, se configura como uma "inversão"; mas o "sujeito invertido" não ocupa a posição de sujeito, e sim uma posição não-argumental adjunta à oração. (KATO \& TARALLO, 1987, p. 20)

Ainda sobre as estruturas de antitópico, Kato \& Tarallo (1987) expõem que, nessas construções, o sujeito invertido não é ele mesmo o sujeito sintático da frase, mas um pronome nulo correferencial. Os autores afirmam que, por isso, esse sujeito nulo deve ter os mesmos traços relevantes (de pessoa, de gênero e de número) que o sujeito invertido, que acionará a concordância verbal correspondente. Por fim, ainda sobre essas construções, Kato \& Tarallo (1987) apontam que, a respeito da ordem de elementos adverbiais: (i) precedem o verbo advérbios de modalidade, frequência e atitude; (ii) ocorrem entre o verbo e o sujeito invertido advérbios de frequência, modo, tempo e lugar; e (iii) não ocorrem depois do sujeito invertido modificadores adverbiais.

\subsubsection{A proposta de Kato \& Tarallo (1993): ordem VS como resultado de diferentes estruturas}

A proposta de Kato \& Tarallo (1993) para a inversão do sujeito em relação ao verbo está relacionada à hipótese de mudanças na gramática do português brasileiro (PB) e à hipótese sobre as estruturas da língua.

De acordo com Kato \& Tarallo (1993), os motivos que levaram o PB a apresentar uma sintaxe de inversão mais restrita do que em outras línguas de sujeito nulo são dois. O primeiro motivo está relacionado ao desaparecimento dos pronomes clíticos de $3^{\mathrm{a}}$ pessoa, os quais foram substituídos ou por pronomes lexicais nominativos ou por categorias nulas. O segundo motivo diz respeito à mudança gradual de língua de sujeito nulo para língua de sujeito não nulo por que passou/passa o português brasileiro.

Em relação às estruturas sintáticas em que uma oração com ordem verbosujeito (VS) pode ocorrer, a análise de Kato \& Tarallo (1993) mostra que orações com ordem VS podem ser resultado de diferentes configurações sintáticas: $V$-fronting e construção de antitópico. De acordo com os autores, a análise de orações com ordem VS deve ser vista, portanto, como um fenômeno sintático que não possui uma única estrutura. 
A estrutura de fronteamento de V, segundo os autores, ocorre quando o sujeito é o foco da oração, como pode ser verificado na sentença (21).
(21) A: Quem chegou?
B: Chegou a Maria.

Em (21), pode-se observar que o verbo seleciona apenas um argumento. Nesse caso, pode haver o movimento do verbo para a esquerda, e o constituinte com a informação de foco fica à direita. Esse tipo de inversão, segundo Kato \& Tarallo (1993), ocorre sempre com verbos inacusativos e com verbos inergativos, já que, de acordo com os autores, esses tipos de verbos compartilham a mesma estrutura quando se apresentam na ordem verbo-sujeito.

Quanto às orações com antitópico, Kato \& Tarallo (1993) defendem que essas ocorrem em contextos em que um constituinte diferente do sujeito é o foco, e o sujeito, por ser informação velha no discurso, ocorre numa posição de tópico. Confira, nesse sentido, o exemplo (22), especialmente a sentença (22B' '):

(22) A: QUANDO o cowboy telefonou?

B: Telefonou ESTA MANHÃ.

B': Ele telefonou ESTA MANHÃ.

B' ': (Ele) Telefonou ESTA MANHÃ, o novo namorado da Xuxa.

Para os autores, em construções de antitópico, a realização do sujeito pode ser nula (22B) ou pronominal (22B'), e em ambos os casos o sujeito pré-verbal, quando pronominal, pode ser predicado pelo antitópico.

Cabe mencionar, ainda, que Kato \& Tarallo (1993) propõem a restrição de mono-argumentalidade, a qual impede a ocorrência da ordem VS com verbos transitivos, com objetos (DPs) manifestos.

\subsubsection{A proposta de Pilati (2002): ordem VS como resultado de diferentes estruturas, inclusive com verbo transitivo e objeto manifesto}

O trabalho de Pilati (2002) buscou determinar os contextos linguísticos de ocorrência da ordem verbo-sujeito (VS) no português do Brasil (PB) e os tipos de verbos que licenciam sujeitos em posição pós-verbal. A autora, apesar de não objetivar a apresentação de 
estruturas sintáticas explicativas para os diferentes casos de ocorrência da ordem verbosujeito, adotou em seu estudo a perspectiva gerativista.

A opção por um trabalho descritivo foi resultado de dois fatos observados por Pilati (2002) em pesquisas publicadas até aquele momento sobre a ordem VS. O primeiro foi que os estudos desenvolvidos sob o enfoque gerativista apresentavam julgamentos conflitantes sobre os contextos de ocorrência do fenômeno. O segundo fato foi o debate publicado na Revista DELTA - em 1989, 1990 e 1992 - de Sebastião Votre e Anthony Naro, pesquisadores da corrente funcionalista, com Milton do Nascimento, pesquisador da corrente gerativista.

Logo no início do trabalho, Pilati (2002) sistematizou as diferentes explicações existentes na literatura sobre a ordem verbo-sujeito, dividindo-as em quatro grupos. No primeiro grupo foram inseridas aquelas explicações em que a ordem seria gerada livremente na sintaxe do PB e barrada posteriormente pelas exigências semânticas da interpretação da construção (cf. Lobato, 1986). No segundo estavam aquelas em que a ordem ocorria somente com verbos que selecionavam um único argumento (Nascimento, 1984). No terceiro grupo, por sua vez, foram inseridas aquelas explicações em que a ordem verbo-sujeito ocorria apenas com verbos que apresentavam um único argumento realizado fonologicamente (Kato \& Tarallo, 1988, 1993). Por fim, no quarto grupo foram inseridas aquelas explicações em que a ordem verbo-sujeito ocorria apenas com verbos inacusativos (Figueiredo Silva, 1996, e Britto, 1998).

Os resultados obtidos por Pilati (2002), apesar de não terem sido quantificados, mostraram que, apesar de verbos inacusativos serem os mais frequentes em orações com ordem VS no PB, há realmente contextos em que orações com ordem VS e verbos inergativos e transitivos são licenciadas na língua.

De acordo com Pilati (2002), as orações na ordem VS com verbos inergativos ocorrem em dois contextos principais: (i) descrições do falante sobre “o que aconteceu?", como em (23a); e (ii) orações com ordem XVS (em que "X" é um adjunto adverbial ou um dêitico), as denominadas inversões locativas, como em (23b):

(23) a. Ligou a Maria.

b. Ali brincam as crianças.

[Pilati, 2002, p. 28 e p. 43] 
Já as orações com ordem VS e verbos transitivos foram encontradas, segundo Pilati (2002), em dois contextos principais: (i) em contextos em que o predicado é previsível, como em narrações concomitantes de eventos esportivos (24a), ou como em contextos instrucionais (24b); e (ii) em orações em que o predicado contém uma expressão idiomática, que também ocorrem em contextos em que o falante está a descrever um acontecimento, como em (24c):

(24) a. Pega a bola o árbitro.

b. Ganha o jogo quem completar o tabuleiro.

c. Tomou posse o novo ministro da educação.

[Pilati, 2002, pp. 36]

A conclusão da pesquisa de Pilati (2002) foi a de que há no PB há orações em que a ordem VS ocorre com verbos inergativos e transitivos. Ademais, concluiu-se que as orações VS com esses tipos de verbo são produtivas na língua, apesar de ocorrerem em contextos específicos.

Segundo Pilati (2002), certos estudos classificam os sujeitos de orações com ordem VS como tópicos deslocados à esquerda. Para esse tipo de análise, a autora destaca que geralmente há uma pausa entre o verbo e o sujeito e há um pronome (fonologicamente nulo ou manifesto) no início da oração, como em (25a). Além disso, Pilati (2002) observa, ainda, que existem orações em que o sujeito à esquerda não tem um pronome nem pausa, como em (25b). Pilati (2002) analisou esses dois tipos de oração e mostrou a diferença semântica entre elas. Veja a análise feita pela autora a partir dos exemplos elaborados por Kato:

(25) a. (Ele) tá pronto, o vestido azul.

b. Tá pronto o vestido azul.

[Kato apud Pilati, 2002, pp. 36-39]

Para ilustrar as diferenças semânticas entre (25a) e (25b) e, consequentemente, para argumentar a favor da existência de diferentes estruturas sintáticas para orações com ordem VS, Pilati (2002) sugere uma determinada situação. O contexto é o seguinte: uma jovem pergunta a sua costureira se as roupas que ela havia encomendado já estão prontas. A pergunta seria (26), a seguir. 
(26) Quais as minhas roupas que estão prontas?

Uma possível resposta seria (27), com a oração entre parênteses subentendida:

(27) Tá pronto o vestido azul. (Os outros vestidos não estão prontos)

Sabendo que uma das peças já estaria pronta, a jovem pergunta:

(28) Já posso levá-lo?

E ouve a seguinte resposta (28'), com uma oração diferente da de (27), como parte subentendida:

(28’) a. (Ele) tá pronto, o vestido azul. (mas ainda não está passado)

Pelo fato de as orações em (25a) e (25b) apresentarem diferentes ideias subentendidas, Pilati (2002) infere que essas orações também apresentam diferentes estruturas sintáticas. Com esse tipo de comparação, Pilati (2002) mostra que é possível haver dois tipos diferentes de orações com ordem VS: (i) uma em que o sujeito é um tópico deslocado à esquerda e (ii) outra em que o sujeito não pode ser interpretado como um tópico.

\subsection{Síntese do capítulo}

Este capítulo procurou, primeiramente, tecer alguns comentários relevantes sobre o modelo teórico no qual esta dissertação está inserida, qual seja o modelo de princípios e parâmetros do Gerativismo. Após analisar o desenvolvimento desse modelo teórico, explicou-se o Princípio de Projeção Estendida (conhecido amplamente na literatura pela abreviatura $E P P$ ) e o Parâmetro pro-drop, os quais, segundo estudos, estão diretamente relacionados à ordem verbo-sujeito (VS).

Sobre o fenômeno da ordem VS, particularmente no português brasileiro (PB), foram apresentadas neste capítulo algumas propostas bastante relevantes. A primeira proposta apresentada foi a de Berlinck (1989), funcionalista, que afirma que a ordem VS diminuiu com o decorrer do tempo, especialmente com verbos transitivos. Em seguida, foram apresentadas as propostas de Nascimento (1984), Kato \& Tarallo (1987) e de Kato \& Tarallo (1993), as 
quais afirmam, respectivamente, que a ordem VS: (i) deve ser entendida como "interpretação de lista", ocorrendo apenas com verbos inergativos e inacusativos; e (ii) seria resultado de diferentes estruturas. Por fim, foi apresentada a proposta de Pilati (2002), que afirma que ordem VS é, sim, resultado de diferentes estruturas, inclusive com verbos transitivos e objeto(s) manifesto(s).

Os trabalhos expostos neste capítulo mostraram que o fenômeno da ordem VS estava diretamente relacionado ao parâmetro pro-drop, com exceção de Pilati (2002), que começa a observar que as orações na ordem VS eram inversões locativas, e que, portanto, não tinham qualquer relação com o parâmetro pro-drop. É importante destacar que, já em Berlinck (1989), sem as observações iniciais de Pilati (2002), os casos de VS que ainda persistiam no PB não eram apenas de VS clássico como o das demais línguas românicas, mas alguns eram casos de inversão locativa, um fenômeno não previsto dentro do parâmetro.

Diante do exposto, no próximo capítulo investigar-se-ão as propriedades das inversões locativas, sendo apresentadas as propostas de Pilati (2002), de Pilati (2006), de Corr (2012) e de Gravina (2014) para esse fenômeno. Cabe destacar que, embora a proposta central de Pilati (2002) já tenha sido apresentada neste capítulo, uma parte específica do trabalho de Pilati (2002) que trata sobre inversão locativa no PB, a qual não foi apresentada neste capítulo, será apresentada no capítulo 2, a fim de uma melhor organização deste trabalho. 


\section{CAPÍTULO 2}

\section{INVERS̃̃O LOCATIVA NO PORTUGUÊS BRASILEIRO}

\subsection{Introdução}

No capítulo anterior, mostrou-se que o fenômeno da ordem verbo-sujeito (VS) no português brasileiro (PB) estava diretamente relacionado ao parâmetro pro-drop, com exceção de Pilati (2002), que começa a observar que as orações na ordem VS eram inversões locativas, e que, portanto, não tinham qualquer relação com esse parâmetro. Com base em Berlinck (1989) e em Pilati (2002), observou-se que alguns casos de VS que ainda persistiam no PB não eram apenas de VS clássico como o das demais línguas românicas, mas eram também casos de inversão locativa.

Diante da afirmação de Pilati $(2002,2006)$ de que orações na ordem VS são inversões locativas, o presente capítulo terá por objetivo apresentar as principais características dessas inversões, especialmente no português brasileiro (PB). A fim de subsidiar o estudo, primeiramente serão apresentadas as considerações de Levin \& Rappaport (1995) a respeito do assunto. Em seguida, serão apresentadas, uma a uma, as propostas de Pilati (2002), de Pilati (2006), de Corr (2012) e de Gravina (2014).

\subsection{O estudo de Levin \& Rappaport (1995) sobre inversão locativa}

As inversões locativas, segundo Levin \& Rappaport (1995), são orações cuja principal função discursiva é a de apresentar um novo referente no contexto do discurso. As autoras afirmam que as inversões locativas são orações apresentativas num sentido mais amplo, pelo fato de que o referente trazido pelo sujeito pós-verbal não precisa ser totalmente novo no discurso, apenas parcialmente novo. Em outras palavras, nas orações em que ocorre inversão locativa, o sujeito pode ser um termo que já tenha sido mencionado, mas que não seja o assunto central da situação do discurso.

De acordo com Levin \& Rappaport (1995), as inversões locativas apresentam uma ordem não-canônica dos elementos - PP VP NP -, em que o elemento denotado pelo PP na posição pré-verbal é tipicamente locativo ou direcional. A respeito dos tipos de verbo (VP), as autoras afirmam que as orações em que ocorre inversão locativa são formadas por 
algumas classes de verbos inergativos e inacusativos. As autoras ressaltam que não são todos os tipos de verbos inergativos ou inacusativos que podem ocorrer em inversão locativa. Para elas, os tipos de verbos que podem ocorrer em tais construções são os que servem para expressar a função discursiva de tal construção, que é a de apresentar elementos no contexto discursivo.

Levin \& Rappaport (1995) consideram também que os verbos presentes em inversão locativa são informacionalmente leves. Isso porque a atividade ou o processo descrito pelo verbo nessas construções são, muitas vezes, características da entidade de que o verbo é predicado. A relação entre entidade e evento é considerada previsível, e, nesse sentido, os verbos são considerados informacionalmente leves.

A característica de conter verbos informacionalmente leves no contexto serve também para que as autoras possam explicar a grande frequência de verbos de existência e de aparecimento em inversões locativas. De acordo com Levin \& Rappaport (1995), esses verbos são leves pelo fato de não trazerem informação além da que é veiculada pelo PP pré-verbal, elemento que, por listar uma cena, sugere que algo existira naquela cena.

Como se pode observar, Levin \& Rappaport (1995) explicam a inversão locativa usando como argumento a função discursiva da oração. Assim, é por causa dessa função discursiva que verbos transitivos não são encontrados nesse tipo de oração, no inglês. Confira, a seguir, um trecho extraído de Levin \& Rappaport (1995):

Typically, in a sentence with a transitive verb new information about the subject is conveyed by the verb and object together. It is unlikely that the subject of such a sentence will represent the least familiar information as the discourse function of the construction requires (such a sentence is likely to be what Guéron (1980) calls a 'predication' rather than a 'presentational' sentence). (LEVIN \& RAPPAPORT, 1995, pp. 231-232)

As poucas construções de inversão locativa que ocorrem com verbos transitivos são formadas por frases fixas como take place e take root, que têm significado associado com um verbo de existência.

Outra característica desse tipo de inversão, atribuída por Levin \& Rappaport (1995), é que seus sujeitos (NP), mesmo que sejam animados, estão de alguma forma desagentivizados.

Resumidamente, as características das inversões locativas do inglês são, segundo Levin \& Rappaport (1995), as seguintes: (i) são orações apresentativas num sentido mais amplo, ou seja, inserem o termo menos familiar, que não precisa ser necessariamente 
novo na situação do discurso; (ii) apresentam a ordem PP VP NP; (iii) contêm PP locativo ou direcional; (iv) ocorrem tipicamente com verbos inergativos ou inacusativos; (v) possuem verbos informacionalmente leves; e (vi) contêm sujeitos desagentivizados. Por fim, cabe destacar que os verbos transitivos apenas são permitidos quando formam estruturas fixas, como take place e take root.

\subsection{Alguns estudos sobre inversão locativa no português brasileiro}

Após a análise do trabalho de Levin \& Rappaport (1995) sobre as principais características das inversões locativas no inglês, serão apresentadas nas subseções a seguir algumas pesquisas sobre esse fenômeno no português brasileiro (PB). Primeiramente, como dito no capítulo anterior, será retomado o trabalho de Pilati (2002), para que seja analisada a seção que apresenta considerações sobre inversão locativa no PB. Em seguida, serão estudadas, uma a uma, as propostas de Pilati (2006), de Corr (2012) e de Gravina (2014) sobre o fenômeno da inversão locativa.

\subsubsection{A análise de Pilati (2002)}

O trabalho de Pilati (2002) mostra que as características da inversão locativa no português brasileiro (PB) são as mesmas daquelas observadas em Levin \& Rappaport (1995) para o inglês. Pilati (2002) exemplifica essa afirmação com base nas sentenças abaixo, em (29):

(29) a. Naquele restaurante, comem os estudantes.

b. Naquela cadeira, senta a noiva, na outra o noivo.

c. Neste brinquedo, brincam crianças de 0 a 6 anos.

[Pilati, 2002, p. 70]

Esses exemplos, de acordo com Pilati (2002), manifestam igualmente as seguintes propriedades: (i) apresentam a ordem PP VP NP; (ii) o PP é locativo ou direcional; (iii) os verbos são informacionalmente leves; e (iv) os sujeitos são desagentivizados.

Pilati (2002) analisa, ainda, as seguintes sentenças, em (30):

(30) a. Neste brinquedo, brincam crianças de 0 a 6 anos.

b. Crianças de 0 a 6 anos brincam neste brinquedo.

[Pilati, 2002, p. 70] 
A oração em (30a), segundo Pilati (2002), apesar de conter um verbo no presente do indicativo, não traz a informação de que as crianças estão brincando naquele brinquedo, e, sim, que "podem brincar" naquele determinado brinquedo se tiverem de 0 a 6 anos. A autora observa, ainda, que, em outro contexto, a oração (30a) também pode significar que "costumam brincar naquele brinquedo" crianças com aquela faixa etária. Já a oração em (30b), de acordo com Pilati (2002), significa que as crianças estão brincando naquele brinquedo. A autora deixa claro que reconhece que a oração (30b) também pode significar, num dado contexto, que as crianças costumam brincar naquele brinquedo, mas destaca que em (30b) o sujeito da oração tem interpretação nitidamente agentiva, o que não ocorre em (30a).

Sobre a questão de os sujeitos serem desagentivizados, Pilati (2002) destaca que esse tipo de informação é veiculado pela oração (31b):

(31) a. João viajou no barco.

b. Viajou um cara super lindo atrás de mim.

[Pilati, 2002, p. 71]

A oração (31b), segundo a autora, significa que havia um cara super lindo e que ele viajava no mesmo veículo que levou a outra pessoa para viajar. Pilati (2002) destaca, ainda, que o elemento cara não recebe interpretação agentiva, como em (31a).

\subsubsection{A análise de Pilati (2006)}

O trabalho de Pilati (2006), que segue a análise descritiva para as orações com ordem verbo-sujeito (VS) feita em Pilati (2002), defende que as orações com ordem VS no português brasileiro (PB) devem ser analisadas como inversão locativa. Na formulação dessa proposta, Pilati (2006) baseia-se no trabalho pioneiro de Nascimento (1984) e nos resultados de Pilati (2002) - em articulação com a proposta de Pinto (1997), elaborada originalmente para as orações com ordem VS no italiano.

As orações denominadas inversões locativas [ou (PP)VS] analisadas em Pilati (2006) são orações declarativas que apresentam as seguintes características: (i) não são respostas a perguntas QU- (32a, a seguir); (ii) são fonologicamente expressas sem pausas longas entre os seus constituintes (32b, a seguir); e (iii) são licenciadas com certos verbos inacusativos, inergativos e transitivos (32c, a seguir).

a. Chegaram as cartas. 
b. Já almoçou todo mundo.

c. Hoje tomou posse o novo ministro da educação.

[Pilati, 2006, p. 172]

Pilati (2006) começa seu estudo sobre as inversões locativas no PB fazendo uma análise da categoria sintática do elemento pré-verbal. Segundo a autora, nas orações com ordem VS no PB, os elementos locativos/temporais (PPs) são locativos como ilustrado no exemplo (33), extraído de Pilati (2006):

(33) Na sexta viaja o Paulo.

[Pilati, 2006, p. 193]

No entanto, Pilati (2006) afirma que há contextos em que a posição pré-verbal pode ser ocupada por elementos dêiticos, como aí (34a, a seguir), ou por operadores de foco, como também, só (34b e 34c, a seguir).

(34) a. Aí liga a D. Maria.

b. Também participa do programa a professora Renata.

c. Só não gostaram do passeio as crianças pequenas.

[Pilati, 2006, p. 193]

Prosseguindo o estudo, Pilati (2006) verifica a possibilidade de o elemento locativo ser nulo, mas com referência recuperada anaforicamente por elementos da situação discursiva. Segundo a autora, assim como no italiano (cf. Pinto, 1997), no PB, o elemento locativo pode ser fonologicamente nulo, desde que seja facilmente recuperado no contexto discursivo. Nesse sentido, confira-se o exemplo (35), extraído de Pilati (2006):

(35) Lá na casa da Maria? Vixe...chegou um monte de coisa.

[Pilati, 2006, p. 194]

Como se pode verificar na sentença em (35), o elemento locativo entre os termos vixe e chegou é fonologicamente nulo, no entanto esse locativo pode ser recuperado facilmente no contex to discursivo, subentendendo-se o termo lá. 
Pilati (2006), ainda sobre a realização nula para o PP, retoma o argumento utilizado por Pinto (1997) para corroborar sua análise de que orações VS são inversões locativas. Pilati (2006) mostra em seu trabalho a interpretação dos exemplos (36a), (37a) e (38a), em comparação com a interpretação de (36b), (37b) e (38b), em que, por meio da glosa, ela confirma que, no PB, assim como no italiano, a ordem VS pressupõe uma interpretação dêitica associada ao estado de coisas descrito pelo predicado:

(36) a. Entrou Dante.

Dante entrou (aqui / nesse lugar)

b. Dante entrou.

Dante entrou (em algum lugar)

(37) a. Morreu Fellini.

Fellini acabou de morrer

(Eu acabei de ouvir que Fellini morreu)

b. Fellini morreu.

(Fellini morreu (há algum tempo))

(38) a. Telefonou Beatriz.

(Beatriz ligou (aqui / para este lugar))

b. Beatriz telefonou.

(Beatriz ligou (para algum lugar / fez telefonemas))

[Pilati, 2006, p. 199]

Com a interpretação obtida nas orações em (36a), (37a) e (38a), Pilati (2006), com base em Pinto (1997), mostra que as orações com ordem VS são interpretadas como se apresentassem um elemento de referência locativa ou temporal com interpretação dêitica. Pilati (2006) afirma que essa mesma análise feita por Pinto (1997) pode ser adotada para as orações com inversão locativa no PB.

Seguindo essa mesma linha de raciocínio, Pilati (2006) afirma que as orações com ordem verbo-objeto-sujeito (VOS) do PB, proferidas em narrações concomitantes, também podem ser analisadas como tendo estruturas semelhantes a inversões locativas, mas 
que, devido ao contexto discursivo em que ocorrem, não apresentam obrigatoriamente um PP em posição inicial. Para essa formulação, a autora apresenta três argumentos.

O primeiro argumento defendido pela autora está relacionado ao fato dessas orações com ordem VOS, proferidas em narrações concomitantes, serem interpretadas como orações com foco identificacional. O segundo, por sua vez, diz respeito ao fato de o contexto discursivo dessas orações deixar evidente que a interpretação do PP locativo é dêitica, pois essas orações descrevem eventos que ocorrem concomitantemente à narração. Por fim, o terceiro argumento está ligado ao fato de poder ser atribuída às orações que ocorrem em contextos previsíveis a mesma interpretação dêitica das orações em (36a), (37a) e (38a).

Para exemplificar os três argumentos defendidos, Pilati (2006) apresenta o exemplo (39), a seguir:

(39) a. (Agora) ergue o braço o juiz.

b. (Nesse momento) pega a bola o goleiro do Flamengo.

[Pilati, 2006, p. 200]

A partir do exemplo (39), a autora mostra que a presença de um elemento locativo na posição inicial não altera a interpretação das sentenças nem interfere na sua gramaticalidade. Pilati (2006) conclui que as orações com ordem VOS também podem ser analisadas como inversões locativas.

A autora afirma que o PB apresenta inversões com verbos transitivos quando as orações com ordem VOS ocorrem: (i) em contextos em que o predicado $(\mathrm{V}+\mathrm{O})$ pode ser interpretado como uma informação antiga ou prevista na situação discursiva, como em (40a) e (40b); ou (ii) quando o predicado é formado por elementos semanticamente leves, como em (40c):

(40) a. Ganha a partida o jogador que fizer mais pontos.

b. Domina a bola o jogador do Vasco.

c. Também faz parte da revista o escritor Alexandre Pilati.

[Pilati, 2006, p. 194]

Sobre as inversões com certos verbos intransitivos, Pilati (2006) lembra que, no $\mathrm{PB}$, os verbos inacusativos são licenciados com maior frequência na ordem VS, mas que nem todos os verbos considerados inacusativos licenciam a ordem VS da mesma forma. Para 
mostrar essas restrições, a autora faz uma comparação entre as orações em (41a) e (41b), a seguir:

(41) a. Aqui chegaram as cartas.
b. *Aqui avermelhou o urubu.

[Pilati, 2006, p. 194]

As orações em (41) revelam, de acordo com Pilati (2006), que verbos de movimento ou que tenham traços relacionados a tempo ou a espaço são mais naturais no licenciamento da inversão. A respeito dessas orações, a autora afirma, ainda, que os verbos que não possuem esse traço semântico relacionado a tempo ou a espaço colocam maiores restrições ao licenciamento da ordem VS, fora de um contexto específico, como em (41b).

Ademais, Pilati (2006) destaca que o exemplo de Bresnan (1994) - repetido em (42), a seguir - mostra que as inversões locativas precisam de contextos específicos para serem licenciadas. Nesse sentido, Pilati (2006) ressalta que essa necessidade por contextos específicos também ocorre nas orações do PB.

(42) A: Estou procurando minha amiga Rose.

B: \#Entre os convidados de honra estava sentada Rose.

C: Rose estava sentada entre os convidados de Rose.

[Pilati, 2006, p. 195]

A oração (42B), segundo Pilati (2006), é inadequada, porque parece depender de um contexto em que existe referência prévia aos convidados de honra, o que a oração em (42A) não oferece. A autora afirma que esse tipo de dependência do contexto para a realização de inversões locativas ocorre também no PB, como observado em (42).

Diante dessas considerações, Pilati (2006) defende que a presença de um elemento locativo (nulo ou manifesto) à esquerda das orações VS é essencial para a derivação dessas construções. A autora defende que orações com ordem VS são, portanto, inversões locativas.

\subsubsection{A análise de Corr (2012)}

O trabalho de Corr (2012) examina as causas do licenciamento da inversão do sujeito no Ibero-Romance, uma propriedade que, segundo ela, tem sido equivocadamente 
relacionada ao parâmetro do sujeito nulo (cf. Chomsky, 1981; Rizzi, 1982). Para o seu estudo, a autora utiliza seis variedades ibero-românicas (asturiano, português europeu, português brasileiro, espanhol peninsular, espanhol mexicano e espanhol rioplatense). A partir dessas variedades, Corr (2012) apresenta dados que oferecem fortes indícios de que há posições de sujeitos pós-verbais no Ibero-Romance e de que SVO, ao invés de VSO, é a ordem padrão nessas variedades.

Corr (2012) sustenta que as abordagens de sujeito nulo de Barbosa (1995) e de Alexiadou \& Anagnostopoulou (1998), envolvendo um EPP parametrizado, ao serem aplicadas ao Ibero-Romance, fazem previsões equivocadas. A autora defende que há um EPP ativo no Ibero-Romance, que não pode ser satisfeito pelas ricas flexões verbais nos tipos de inversões do sujeito analisados em seu trabalho. Segundo a autora, esse EPP ativo é satisfeito por um argumento locativo nulo (cf. Pinto 1997) ou por um nulo expletivo existencial.

Para explicar a complexidade e a sistematicidade da inversão do sujeito envolvendo um locativo nulo no Ibero-Romance, Corr (2012) postula uma análise do locativo nulo como PP em camadas, sendo que existem quatro instâncias disponíveis de forma desigual em todas as seis variedades. Essa análise, segundo a autora, aproxima a inversão do sujeito locativo e a inversão locativa evidente, o que torna possível a unificação dessas em uma única análise. Além disso, a variação sistemática no Ibero-Romance pode ser explicada por onde os PPs locativos aparecem: (i) na fronteira TP / CP e (ii) na periferia esquerda.

Seguindo Benincà (1998), Pinto (1997), Tortora (2001) e Sheehan (2006, 2010), Corr (2012) postula que a ordem VS nessas línguas é um tipo de inversão locativa, porém a autora se diferencia dos demais estudiosos ao defender uma análise mais refinada do elemento locativo relevante em tais construções de inversão. Esse elemento locativo, segundo Corr (2012), está disponível de forma desigual em todo Ibero-Romance e pode aparecer em posições diferentes na parte superior da arquitetura sentencial, levando à variação microparamétrica. Como o objetivo desta dissertação está relacionado especificamente ao português brasileiro, não serão analisados neste trabalho os estudos feitos pela a autora acerca da variação microparamétrica da posição do elemento locativo.

Prosseguindo o trabalho, Corr (2012) afirma que os dados mostram que o licenciamento de inversão locativa não é dependente nem do parâmetro do sujeito nulo, uma vez que esse tipo de inversão também ocorre em variedades de sujeito nulo parcial e em variedades de sujeito pleno, nem da divisão entre inacusativos e inergativos, embora exista em ambos os casos um grau de correspondência. Em vez disso, Corr (2012) defende que esse tipo de construção é uma consequência de recursos dêiticos gramaticalmente codificados que se 
correlacionam com as propriedades semânticas dos verbos envolvidos em tais casos de inversão.

Corr (2012) observa que o asturiano, o português europeu e o espanhol são variedades muito semelhantes e que todas essas são línguas de sujeito nulo. Já em relação ao português brasileiro, a autora afirma que essa língua é uma exceção. Isso porque o português brasileiro vem sendo considerado, segundo a autora, uma língua de sujeito nulo parcial, e, portanto, apresenta uma maior restrição ao fenômeno da inversão. ${ }^{8}$

Corr (2012) faz uma análise da distribuição da ordem no Ibero-Romance a partir da tipologia do verbo. Primeiramente, a autora analisa a ordem com verbos transitivos. Em seguida, o fenômeno da ordem foi analisado com alguns verbos intransitivos, descobrindo-se que não havia alternância da ordem com alguns verbos desse tipo. Por fim, destacam-se os verbos intransitivos, em que houve alternância entre a ordem SV e VS. Cabe destacar que a análise do espanhol latino-americano corresponde ao conjunto espanhol mexicano e espanhol rioplatense.

\subsubsection{Ordem VS com verbos transitivos}

De acordo com Corr (2012), nas seis variedades do Ibero-Romance analisadas, o sujeito aparece em posição inicial com verbos transitivos em contextos de foco largo. Os exemplos de (43) a (46) mostram, a seguir, a possibilidade de inversão com verbos transitivos nas seis variedades do Ibero-Romance estudadas por Corr (2012):

(43) a. Alexandro com-ió el pan. [ASTURIANO]

Alexandro eat-PST.3SG the bread

b. *Com-ió Alexandro el pan.

eat-PST.3SG Alexandro the bread

(44) a. Alejandro ha com-ido el pan. [ESPANHOL PENINSULAR]

Alejandro AUX eat-PST.PTCP the bread

b. *Ha com-ido Alejandro el pan.

AUX eat-PST.PTCP Alejandro the bread

8 Para maiores detalhes sobre o que consiste uma língua de sujeito nulo parcial ver Rodrigues (2004) e Hornstein et al. (2010). 
(45) a. Alejandro com-ió el pan. [ESPANHOL LATINO-AMERICANO]

Alejandro eat-PST.3SG the bread

b. *Com-ió Alejandro el pan.

eat-PST.3SG Alejandro the bread

(46) a. O Alexandro com-eu o pão. [PORTUGUÊS EUROPEU]

[PORTUGUÊS BRASILEIRO]

the Alexandro eat-PST.3SG the bread

b. *Com-eu o Alexandro o pão.

eat-PST.3SG the Alexandro the bread

'Alexander has eaten/ate the bread.'

As sentenças em (43) a (46) revelam que, com exceção do português europeu e do português brasileiro, a ordem VS com verbos transitivos não é possível. Isso revela, considerando a amplitude de variedades do Ibero-Romance, que a ocorrência da ordem VS é bastante restrita com verbos transitivos.

\subsubsection{Ordem VS com verbos intransitivos sem alternância de ordem}

Corr (2012) mostra que todas as seis variedades do Ibero-Romance apresentam inversão com os verbos asoceder/ocurrir/acontecer, verbos esses considerados inacusativos. Os exemplos de (47) a (50) mostram, a seguir, a análise com verbos intransitivos sem alternância de ordem, nas seis variedades do Ibero-Romance estudadas por Corr (2012):

(47) Asoced-ió un accidente. [ASTURIANO]

happen-PST.3SG an accident

(48) Ha ocurr-ido un accidente. [ESPANHOL PENINSULAR]

AUX occur-PST.3SG an accident

(49) Ocurr-ió un accidente. [ESPANHOL LATINO-AMERICANO]

happen-PST.3SG an accident 
(50) Acontec-eu um acidente. [PORTUGUÊS EUROPEU]

\section{[PORTUGUÊS BRASILEIRO]}

happen-PST.3SG an accident

'An accident (has) happened.'

As sentenças em (47) a (50) mostram a possibilidade de ocorrência da inversão com verbos intransitivos sem alternância de ordem em todas as seis variedades. Corr (2012) também mostra, nos exemplos de (51) a (55), a possibilidade de inversão do sujeito com os verbos inacusativos apaecer/aparecer, embora, segundo a autora, uma minoria de falantes do português brasileiro prefira a ordem não invertida:

(51) Apaec-ió un perru. [ASTURIANO]

appear-PST.3SG a dog

(52) Ha aparec-ido un perro. [ESPANHOL PENINSULAR]

AUX appear-PST.PTCP a dog

(53) Aparec-ió un perro. [ESPANHOL LATINO-AMERICANO]

appear-PST.3SG a dog

(54) Aparec-eu um cão. [PORTUGUÊS EUROPEU]

[PORTUGUÊS BRASILEIRO]

appear-PST.3SG a dog

(55) Um cão aparec-eu. [PORTUGUÊS BRASILEIRO]

a dog appear-PST.3SG

'A dog (has) appeared.'

Com base nas sentenças de (51) a (55), Corr (2012) defende que, como verbos de apresentação, esses verbos são normalmente usados com um DP indefinido, o que é suscetível de afetar a configuração da ordem das palavras. No entanto, segundo a autora, mesmo quando o DP é definido, como apaecer/aparecer, em asturiano e espanhol peninsular a ordem VS ainda é licenciada, tal como em (56) e (57), a seguir expostas. 
(56) Apaec-ió Fido. [ASTURIANO]

appear-PST.3SG Fido

(57) Ha aparec-ido Fido. [ESPANHOL PENINSULAR]

AUX appear-PST.PTCP Fido

'Fido (has) appeared.'

Todos os exemplos anteriores mostram, segundo Corr (2012), que há possibilidade de inversão com verbos intransitivos sem alternância de ordem, nas seis variedades do Ibero-Romance estudadas pela a autora.

\subsubsection{Ordem VS com verbos intransitivos com alternância VS / SV}

Corr (2012) afirma que os verbos intransitivos to arrive e to come permitem tanto a ocorrência de SV como de VS. Para defender essa afirmação, a autora apresenta o exemplo em (58), a seguir:

(58) a. A avó cheg-ou. [PORTUGUÊS EUROPEU]

\section{[PORTUGUÊS BRASILEIRO]}

the grandmother arrive-PST.3SG

b. Cheg-ou a avó.

arrive-PST.3SG the grandmother

'Grandmother arrived.'

A sentença em (58a) mostra a possibilidade de ocorrência da ordem SV com os verbos intransitivos to arrive e to come. A sentença em (58b), por sua vez, mostra a possibilidade de ocorrência da ordem VS com esses mesmos verbos intransitivos. O exemplo anterior revela que essas duas possibilidades de ordem ocorrem tanto no português europeu quanto no português brasileiro.

Para sistematizar esses os estudos, Corr (2012) apresenta uma tabela (Tabela 6, nesta dissertação) que resume os verbos que favorecem a inversão do sujeito nas seis variedades do Ibero-Romance analisadas pela autora. 
Tabela 6 - Verbos desencadeantes da inversão do sujeito nas seis variedades analisadas do Ibero-Romance

\begin{tabular}{|c|c|c|c|c|c|c|}
\hline & Ast & IS & $\mathbf{R S}$ & MS & EP & BP \\
\hline Happen & VS & VS & VS & VS & VS & VS/SV \\
\hline Appear & VS & VS & VS & VS & VS & VS/SV (?) \\
\hline Arrive & VS/SV & VS/SV & $\mathrm{VS} / \mathrm{SV}$ & VS/SV & SV/VS & SV/VS \\
\hline Come & VS/SV & VS/SV & VS/SV & VS/SV & SV/VS & SV/VS \\
\hline Call & VS/SV & VS/SV & $\mathrm{VS} / \mathrm{SV}$ & SV/VS & SV/VS & SV/VS \\
\hline Enter & VS/SV & VS/SV & SV/VS & SV/VS & SV/VS & SV/VS \\
\hline Die & VS/SV & VS/SV & SV/VS & SV/VS & SV/VS & SV/VS \\
\hline Leave (irse) & / & SV/VS & SV/VS & SV/VS & I & I \\
\hline Leave (salir) & SV/VS & SV/VS & SV/VS & SV/VS & SV & SV \\
\hline Cry & SV/VS & SV & SV & SV & SV & SV \\
\hline Shout & $\mathrm{SV} / \mathrm{VS}$ & SV & SV & SV & SV & SV \\
\hline Resign & SV/VS & SV & SV & SV & SV & SV \\
\hline Jump & SV & SV & SV & SV & SV & SV \\
\hline
\end{tabular}

Fonte: Corr (2012, p. 19)

Corr (2012) observa que os verbos da inversão no Ibero-Romance parecem não seguir totalmente a distinção inacusativos/inergativos, embora haja alguma correspondência. A autora, no entanto, destaca que (com exceção de alguns verbos em asturiano) verbos geralmente inergativos não permitem a inversão do sujeito em contextos de foco largo juntamente com a inaceitabilidade de inversão com verbos transitivos em contextos de foco largo em todo o Ibero-Romance. Isso sugere, de acordo com Corr (2012), que: (i) SVO é a ordem padrão do Ibero-Romance; e (ii) um elemento na superfície em SpecTP é necessário para satisfazer o EPP. ${ }^{9}$ Parece plausível, segundo a autora, que este elemento seja o LOC nulo, como postulado por Pinto (1997). Sujeitos pré-verbais parecem estar em posições nãoargumentais.

Ademais, Corr (2012) argumenta que - uma vez que a inversão discutida em seu trabalho também pode ser encontrada no português brasileiro, uma língua de sujeito nulo parcial - este tipo de inversão "livre" não pode ser apenas uma propriedade de línguas de sujeito nulo consistente. Como tal, a autora defende que estes casos de inversão não parecem ser uma consequência direta do Parâmetro do Sujeito Nulo.

Em suma, Corr (2012) defende que VS nas línguas românicas analisadas não pode ser consequência do parâmetro do Sujeito Nulo, uma vez que há VS em PB, uma língua de Sujeito Nulo Parcial. A autora segue Pinto (1997) e afirma que a ordem VS nessas línguas

9 Como visto no capítulo 1 desta dissertação, a sigla EPP é decorrente da expressão do inglês Extended Projection Principle. 
corresponde a casos de inversões locativas, nas quais um elemento LOC está sintaticamente presente e satisfaz o EPP de T. Para Corr (2012), a alternância entre SV e VS é relacionada à disponibilidade e à seleção de um elemento LOC. Para a autora, VS é um fenômeno lexicalmente condicionado e que não tem relação forte com a divisão entre verbos inacusativos e inergativos (embora haja certa correspondência).

\subsubsection{A análise de Gravina (2014)}

O objetivo principal de Gravina (2014) é o estudo da relação entre sujeito nulo parcial e inversão do sujeito em relação ao verbo (ordem VS), particularmente na diacronia. Para subsidiar sua pesquisa, a autora faz durante todo o seu trabalho um estudo comparativo entre o português brasileiro (PB) e o português europeu (PE). ${ }^{10}$

Inicialmente, Gravina (2014) analisa, sob uma perspectiva diacrônica, os contextos de restrições do sujeito nulo no PB e os do sujeito nulo no PE, a fim de buscar uma resposta à seguinte pergunta: “o aumento do preenchimento do sujeito na diacronia do PB encontrado em dados de jornais teria ocorrido por questões estilísticas ou sintáticas?". Em momento posterior, Gravina (2014) postula que o Sujeito Lexical Anafórico não seria apenas um recurso estilístico do gênero jornalístico, mas estaria se tornando um recurso utilizado pelo gênero mais formal, com o intuito de se evitar que a posição sintática do sujeito ficasse nula. ${ }^{11}$ Em seguida, Gravina (2014) levanta as hipóteses de os contextos com inversão no PB estarem diminuindo com o decorrer do tempo e de os ambientes de realização dessas inversões no PB serem diferenciados dos ambientes sintáticos em que se encontram VS no $\mathrm{PE}$, diacronicamente.

Os corpora de Gravina (2014) foram compostos de seis jornais - três referentes ao PB e três referentes ao PE. Os três jornais do PB utilizados foram: (i) O Recreador Mineiro (1845 a 1848); (ii) Jornal Mineiro (1887 a 1900); e (iii) Tribuna de Ouro Preto (1945 a 1948). Já os três jornais do PE utilizados foram: (i) A Illustração luso-brazileira (1854 a 1858); (ii) O Manuelinho d'Évora (1888 a 1895); e (iii) Notícias d'Évora (1945 a 1948). Com

10 É interessante observar que o trabalho de Gravina (2014), apesar de defender que as orações com ordem VS no PB são casos de inversão locativa, tem como objetivo estabelecer uma relação com a ordem VS e a classificação do PB como língua de sujeito nulo parcial. Conforme será defendido a seguir, seguindo Corr (2012), as inversões locativas do PB não são um fenômeno relacionado ao Parâmetro do Sujeito Nulo.

11 A expressão "Sujeito Lexical Anafórico" é utilizada por Gravina $(2008,2014)$ para classificar o sujeito sempre quando esse pode ser substituído ou por um sujeito nulo ou por um pronome lexical realizado em contextos referenciais anafóricos. Exemplo extraído de Gravina (2014, p. 19, grifos da autora): (0) Charlotte é docente do curso de Linguística na Universidade Estadual de Campinas. A pesquisadora trabalha essencialmente na área de Linguística Histórica. Esta é sempre solicitada nos mais diversos congressos de sua área. 
base nesses corpora, Gravina (2014) realizou análises quantitativa e qualitativa acerca da ordem VS tanto em relação ao PB quanto em relação ao PE. Nessa análise, a autora traz contribuições relevantes sobre inversão locativa.

Gravina (2014) observa que, em relação à inversão do sujeito, não foram identificadas diferenças quantitativas de usos entre o PB e o PE. Segundo a autora, as duas línguas apresentaram valores bem próximos de realização de inversão no decorrer do tempo. Essa análise quantitativa foi obtida a partir da divisão dos dados do PB e do PE em dois grandes grupos. No primeiro grupo, referente aos tipos de sentenças, foram inseridos os dados com: (i) inversão do sujeito com verbos em construções parentéticas, isto é, orações com verbos que se encontravam em contextos de referência a algo que se havia dito; e (ii) inversão do sujeito em sentenças interrogativas. No segundo grupo, referente aos tipos de verbo, foram inseridos os dados com: (i) inversão do sujeito com verbos inacusativos; (ii) inversão do sujeito com verbos transitivos; (iii) inversão do sujeito em construções com verbos estar/ficar; e (iv) inversão do sujeito em construções com verbos inergativos. Confira a seguir as seguintes tabelas, extraídas de Gravina (2014) sobre os dados do PB:

Tabela 7 - Distribuição de cada contexto selecionado para análise no Jornal Recreador Mineiro (Século XIX - 1845 a 1848)

\begin{tabular}{ccccccc}
\hline & Parentética & Interrogativa & Inacusativo & Transitivo & Estar/Ficar & Inergativo \\
\hline \multirow{2}{*}{$S V$} & $0 / 34$ & $3 / 9$ & $24 / 58$ & $411 / 484$ & $25 / 32$ & $70 / 78$ \\
& $0 \%$ & $33 \%$ & $41 \%$ & $85 \%$ & $78 \%$ & $90 \%$ \\
& & & & & & \\
VS & $34 / 34100 \%$ & $6 / 9$ & $34 / 58$ & $70 / 484$ & $7 / 32$ & $8 / 78$ \\
& & $77 \%$ & $59 \%$ & $15 \%$ & $22 \%$ & $10 \%$ \\
\hline
\end{tabular}

Fonte: Gravina (2014, p. 172)

A tabela 7 mostra que, durante o século XIX (1845 a 1848), no Jornal Recreador Mineiro, a ordem VS prevalecia sobre a ordem SV nos seguintes contextos: (i) em orações parentéticas; (ii) em orações interrogativas e (iii) em orações com verbos inacusativos. Nas orações com verbos transitivos e inergativos e naquelas com os verbos estar/ficar, a ordem que prevalecia era a ordem SV. 
Tabela 8 - Distribuição de cada contexto selecionado para análise no Jornal Mineiro

(Século XIX - 1890 a 1900)

\begin{tabular}{ccccccc}
\hline & Parentética & Interrogativa & Inacusativo & Transitivo & Estar/Ficar & Inergativo \\
\hline \multirow{2}{*}{ SV } & $0 / 25$ & $16 / 24$ & $29 / 74$ & $545 / 628$ & $52 / 59$ & $51 / 57$ \\
& $0 \%$ & $67 \%$ & $40 \%$ & $87 \%$ & $88 \%$ & $90 \%$ \\
\multirow{2}{*}{$V S$} & $25 / 25$ & $8 / 24$ & $45 / 74$ & $83 / 628$ & $7 / 59$ & $6 / 57$ \\
& $100 \%$ & $33 \%$ & $60 \%$ & $13 \%$ & $12 \%$ & $10 \%$ \\
\hline
\end{tabular}

Fonte: Gravina (2014, p. 172)

A tabela 8 mostra que, durante o século XIX (1890 a 1900), no Jornal Mineiro, a ordem VS prevalecia sobre a ordem SV nos seguintes contextos: (i) em orações parentéticas e (ii) em orações com verbos inacusativos. Nas orações interrogativas e naquelas com verbos transitivos, inergativos e com os verbos estar/ficar, a ordem que prevalecia era a ordem SV.

Tabela 9 - Distribuição de cada contexto selecionado para análise no Jornal Tribuna de Ouro Preto (Século XX - 1945 a 1948)

\begin{tabular}{ccccccc}
\hline & Parentética & Interrogativa & Inacusativo & Transitivo & Estar/Ficar & Inergativo \\
\hline \multirow{2}{*}{$S V$} & $0 / 21$ & $2 / 2$ & $51 / 92$ & $480 / 547$ & $36 / 47$ & $53 / 66$ \\
& $0 \%$ & $100 \%$ & $56 \%$ & $87 \%$ & $77 \%$ & $81 \%$ \\
\multirow{2}{*}{$V S$} & $21 / 21$ & $0 / 2$ & $41 / 92$ & $60 / 547$ & $11 / 47$ & $13 / 66$ \\
& $100 \%$ & $0 \%$ & $44 \%$ & $10 \%$ & $23 \%$ & $19 \%$ \\
\hline
\end{tabular}

Fonte: Gravina (2014, p. 172)

A tabela 9 mostra que, durante o século XX (1945 a 1948), no Jornal Tribuna de Ouro Preto, a ordem VS prevalecia sobre a ordem SV apenas no contexto de orações parentéticas. Em todos os demais contextos, a ordem SV era a que predominava.

Sobre os dados do PE, confira a seguir as tabelas de 10 a 12, extraídas de Gravina (2014). 
Tabela 10 - Distribuição de cada contexto selecionado para análise no Jornal Illustração Luso-Brasileira

(Século XIX - 1850 a 1855)

\begin{tabular}{ccccccc}
\hline & Parentética & Interrogativa & Inacusativo & Transitivo & Estar/Ficar & Inergativo \\
\hline \multirow{2}{*}{$S V$} & $0 / 9$ & $4 / 9$ & $26 / 60$ & $581 / 672$ & $30 / 41$ & $110 / 142$ \\
& $0 \%$ & $45 \%$ & $44 \%$ & $86 \%$ & $73 \%$ & $78 \%$ \\
\multirow{2}{*}{$V S$} & $9 / 9$ & $5 / 9$ & $34 / 60$ & $91 / 672$ & $11 / 41$ & $32 / 142$ \\
& $100 \%$ & $55 \%$ & $56 \%$ & $14 \%$ & $37 \%$ & $22 \%$ \\
\hline
\end{tabular}

Fonte: Gravina (2014, p. 173)

A tabela 10 mostra que, durante o século XIX (1850 a 1855), no Jornal Illustração Luso-Brasileira, a ordem VS prevalecia sobre a ordem SV nos seguintes contextos: (i) em orações parentéticas; (ii) em orações interrogativas; e (iii) em orações com verbos inacusativos. Nas orações com verbos transitivos, inergativos e naquelas com os verbos estar/ficar, a ordem que prevalecia era a ordem SV.

Tabela 11 - Distribuição de cada contexto selecionado para análise no Jornal Manuelinho de Évora

(Século XIX - 1888 a 1895)

\begin{tabular}{ccccccc}
\hline & Parentética & Interrogativa & Inacusativo & Transitivo & Estar/Ficar & Inergativo \\
\hline \multirow{2}{*}{$S V$} & $0 / 15$ & $7 / 16$ & $23 / 53$ & $516 / 620$ & $44 / 67$ & $100 / 120$ \\
& $0 \%$ & $44 \%$ & $44 \%$ & $83 \%$ & $65 \%$ & $83 \%$ \\
\multirow{2}{*}{$V S$} & $15 / 15$ & $9 / 16$ & $30 / 53$ & $104 / 620$ & $23 / 67$ & $20 / 120$ \\
& $100 \%$ & $56 \%$ & $56 \%$ & $17 \%$ & $35 \%$ & $17 \%$ \\
\hline
\end{tabular}

Fonte: Gravina (2014, p. 173)

A tabela 11 mostra que, durante o século XIX (1888 a 1895), no Jornal Manuelinho de Évora, a ordem VS prevalecia sobre a ordem SV nos seguintes contextos: (i) em orações parentéticas; (ii) em orações interrogativas; e (iii) em orações com verbos inacusativos. Nas orações com verbos transitivos, inergativos e naquelas com os verbos estar/ficar, a ordem que prevalecia era a ordem SV. 
Tabela 12 - Distribuição de cada contexto selecionado para análise no Jornal Notícias de Évora (Século XX - 1945 a 1948)

\begin{tabular}{ccccccc}
\hline & Parentética & Interrogativa & Inacusativo & Transitivo & Estar/Ficar & Inergativo \\
\hline \multirow{2}{*}{ SV } & $0 / 25$ & $4 / 16$ & $27 / 66$ & $480 / 592$ & $51 / 75$ & $110 / 134$ \\
& $0 \%$ & $25 \%$ & $40 \%$ & $81 \%$ & $68 \%$ & $82 \%$ \\
& & & & & & \\
\multirow{2}{*}{$V S$} & $25 / 25$ & $12 / 16$ & $39 / 66$ & $112 / 592$ & $24 / 75$ & $24 / 134$ \\
& $100 \%$ & $75 \%$ & $60 \%$ & $19 \%$ & $32 \%$ & $18 \%$ \\
\hline
\end{tabular}

Fonte: Gravina (2014, p. 173)

A tabela 12 mostra que, durante o século XX (1945 a 1948), no Jornal Notícias de Évora, a ordem VS prevalecia sobre a ordem SV nos seguintes contextos: (i) em orações parentéticas; (ii) em orações interrogativas; e (iii) em orações com verbos inacusativos. Nas orações com verbos transitivos, inergativos e naquelas com os verbos estar/ficar, a ordem que prevalecia era a ordem SV.

De acordo com Gravina (2014), o contexto de sentenças parentéticas mostrouse como um ambiente categórico de inversão. Em razão desse número expressivo, a autora retirou da análise essas sentenças, o que significou uma diminuição no número de inversões de sujeito nos textos brasileiros.

Em relação ao contexto de sentenças interrogativas, Gravina (2014) mostra que, apesar de o PB conter poucos dados, esse contexto revelou que, a partir do final do século XIX, houve uma preferência por manter a ordem SV. Os dados mostraram ainda, segundo a autora, que, para o PE, a tendência é ter ainda um maior número de interrogativas com ordem VS na língua.

Quanto às classes de verbos, Gravina (2014) destaca que a realização de inversões com verbos transitivos foi o que mais lhe chamou a atenção. Sobre esses tipos de verbo, a autora observa que, principalmente na primeira metade do século $\mathrm{XX}$, enquanto no PB havia uma maior tendência em produzir XVS e VOS, no PE havia uma tendência de se ter o verbo em terceira posição (XOVS) e uma alta produção de VS. ${ }^{12}$ Confira-se, a seguir, as tabelas 13 e 14, que resumem essa proporção de inversão no PB e no PE, respectivamente.

12 Gravina (2014, p. 184) indica como " $\mathrm{X}$ " elementos diferentes de argumentos, sejam internos ou externos. Assim, de acordo com a autora, esse " $X$ " pode ser advérbio ou locução adverbial, aposto, ou mesmo algum elemento do discurso. 
Tabela 13: Proporção de cada tipo de inversão no PB

\begin{tabular}{|c|c|c|c|c|c|c|c|}
\hline & $V S$ & $X V S$ & VOS & $X V O S$ & $O V S$ & XOVS & $V X S$ \\
\hline $\begin{array}{l}\text { Recreador } \\
\text { Mineiro }\end{array}$ & $\begin{array}{l}22 / 72 \\
30 \%\end{array}$ & $\begin{array}{l}28 / 72 \\
39 \%\end{array}$ & $9 / 7212 \%$ & $\begin{array}{l}1 / 72 \\
0,5 \%\end{array}$ & $\begin{array}{l}7 / 72 \\
10 \%\end{array}$ & $4 / 725 \%$ & $\begin{array}{r}3 / 72 \\
3,5 \%\end{array}$ \\
\hline Jornal Mineiro & $\begin{array}{c}15 / 83 \\
18 \%\end{array}$ & $\begin{array}{c}43 / 83 \\
52 \%\end{array}$ & $\begin{array}{c}10 / 83 \\
12,5 \%\end{array}$ & $2 / 832 \%$ & $\begin{array}{c}5 / 83 \\
6 \%\end{array}$ & $\begin{array}{r}8 / 83 \\
9,5 \%\end{array}$ & $\begin{array}{c}0 / 83 \\
0 \%\end{array}$ \\
\hline $\begin{array}{c}\text { Tribuna de Ouro } \\
\text { Preto }\end{array}$ & $\begin{array}{l}13 / 61 \\
21 \%\end{array}$ & $\begin{array}{l}22 / 61 \\
33 \%\end{array}$ & $\begin{array}{l}22 / 61 \\
37 \%\end{array}$ & $3 / 614 \%$ & $\begin{array}{l}0 / 61 \\
0 \%\end{array}$ & $\begin{array}{l}1 / 61 \\
1,5 \%\end{array}$ & $\begin{array}{l}2 / 61 \\
3,5 \%\end{array}$ \\
\hline
\end{tabular}

Fonte: Gravina (2014, p. 187)

Tabela 14: Proporção de cada tipo de inversão no PE

\begin{tabular}{cccccccc}
\hline & VS & XVS & VOS & XVOS & OVS & XOVS & VXS \\
\hline Ilustração luso- & $27 / 91$ & $8 / 91$ & $7 / 91$ & $10 / 91$ & $2 / 91$ & $34 / 91$ & $3 / 91$ \\
brazileira & $30,5 \%$ & $9 \%$ & $7,5 \%$ & $11 \%$ & $2 \%$ & $37 \%$ & $3 \%$ \\
& & & & & & & \\
Manuelinho de & $24 / 100$ & $4 / 100$ & $6 / 100$ & $8 / 100$ & $4 / 100$ & $48 / 100$ & $6 / 100$ \\
$\quad$ Évora & $24 \%$ & $4 \%$ & $6 \%$ & $8 \%$ & $4 \%$ & $48 \%$ & $6 \%$ \\
Notícias de & $17 / 119$ & $3 / 116$ & $12 / 119$ & $13 / 119$ & $4 / 119$ & $63 / 119$ & $7 / 119$ \\
$\quad$ Évora & $14,5 \%$ & $2,5 \%$ & $10 \%$ & $11 \%$ & $3 \%$ & $53 \%$ & $6 \%$ \\
\hline
\end{tabular}

Fonte: Gravina (2014, p. 187)

Ainda sobre a questão observada por Gravina (2014) a respeito dos verbos transitivos, confira a seguir os exemplos (59) e (60), respectivamente do PB e do PE:

(59) Nas minerações de ouro, 'a terra parece, que evapora tumultos: a agua exalla motins; o ouro foco desaforos: destilam Liberdades os ares: vomitam insolências as nuvens: influyem desordens os astros: o clima hé tumba da paz e berço da rebelliam: a natureza anda inquéta comsigo, e amotinada lá por dentro, é como no inferno: Bramão graves trovões continuamente, Donde se precipita o rayo ardente.

(60) Serão oradores nesta cidade os distintos homens públicos Doutor Mario de Albuquerque, professor da Faculdade de Letras da Universidade de Lisboa e deputado, e Engenheiro Sebastião Ramires, deputado e antigo Ministro e vogal da Comissão Executiva da União Nacional.

A sessão será presidida pelo Senhor Governador Civil e pronunciará algumas palavras de apresentação o sr. Dr. Camarate de Campos, ilustre presidente da Comissão Distrital da União Nacional. (Notícias de Évora, 1946).

[Gravina, 2014, pp. 217-218] 
Os dados em (59) e em (60) revelam que, enquanto no PB observava-se um aumento na taxa de produção de ordens VOS, no PE se observava uma taxa maior da ordem XOVS. Gravina (2014) destaca que, ao analisar a interpretação de VOS nos dados do PB, observou-se que toda a sentença estava focalizada, sendo toda essa uma informação nova no contexto. Ao fazer um paralelo com o resultado da inversão VOS em PE, Gravina (2014) chega à conclusão de que, diferentemente do PB, no PE apenas o sujeito é o foco da sentença, ou seja, apenas o sujeito é a informação nova no contexto. A consequência dessa análise para a derivação, de acordo com a autora, é a de que todos os elementos estão em uma posição mais alta, diferentemente do PE, que, na ordem VOS, tem a interpretação de foco apenas no sujeito.

Continuando a análise quanto à classe de verbos, Gravina (2014) afirma que com os verbos monargumentais (inacusativos e inergativos) têm-se as situações mais esperadas: enquanto os verbos inacusativos favorecem um maior uso da inversão do sujeito por selecionarem apenas argumentos internos, os verbos inergativos apresentam altos índices de ordem SV, tanto no PB, quanto no PE.

Gravina (2014) afirma que a ordem VS é bastante produtiva com verbos inacusativos nas duas línguas, mas que, nesse caso, a posição do verbo diferencia o PB do PE. Segundo a autora, enquanto no PB há uma maior tendência de haver algum constituinte anterior ao verbo (XVS), no PE o verbo inacusativo em primeira posição é contexto de maior ocorrência da ordem VS. Isso mostra claramente que, no PB, a ordem VS era inversão locativa.

Para explicar a derivação do tipo XVS em construções inacusativas, Gravina (2014), com base em Pilati (2006) e em Sheehan (2010), assume a presença de um locativo/expletivo nulo, como em (61a) e (61b), ou de um elemento adverbial, como em (61c), ambos anteriores ao verbo. Com base em Pinto (1994, 1997), Gravina (2014) afirma que, em sentenças com verbos inacusativos, a derivação seria explicada devido à presença de um argumento nulo locativo, nesse sentido:

(61) a. Nasceu El-Rei Dom João II. (Tribuna de Ouro Preto, 1945)

b. Existem poucas propriedades de casas com vidraças. (Recreador, 1846)

c. $1^{\circ}$ de abril chegou El rei à província. (Recreador, 1847)

[Gravina, 2014, pp. 205-206] 
Nas sentenças em (61), a autora afirma que o verbo inacusativo gera um argumento nulo locativo que é movido para o SpecT, satisfazendo o EPP da sentença e mantendo-se a ordem da sentença. ${ }^{13}$ Gravina (2014), citando Sheehan (2010), apresenta o exemplo abaixo, de Ambar (1992), para fundamentar sua hipótese:

(62) a. LOC chegaram os técnicos ontem.

b. A Lisboa chegaram os técnicos ontem.

[Gravina, 2014, p. 205]

$\mathrm{Na}$ sentença em (62a), o argumento nulo locativo, de acordo com Gravina (2014), é o responsável por satisfazer o EPP da sentença. Já na sentença em (62b), o PP é responsável por satisfazer o EPP, e não o locativo nulo.

Gravina (2014) defende que a preferência nos dados do PB por construções XVS com elemento adverbial realizado, como em (61c), pode ser interpretada como indícios de uma tendência por ter a primeira posição preenchida por algum elemento que possa efetuar a função de sujeito, mesmo que esse não seja o sujeito real da sentença. Segundo a autora, esse indício é importante, já que há mais de $80 \%$ de ordem SV nos dados do PB - e, quando há inversões, essa ordem é a que possui maior frequência.

Sobre os verbos inergativos, Gravina (2014) afirma que, quantitativamente, tanto o PB quanto o PE apresentam altos índices de ordem SV. A autora destaca que, comparativamente, o PE permite mais inversões com verbos inergativos do que o PB. Gravina (2014) mostra, também, que, na primeira metade do século XX, representada pelo Jornal Tribuna de Ouro Preto, as inversões ocorriam prioritariamente na ordem VXS.

Em relação, por fim, à ocorrência de inversão com os verbos estar/ficar, Gravina (2014) observou que esses verbos possuem uma maior produção com a ordem VS. Essa afirmação refere-se tanto aos dados do PE quanto do PB. A autora destaca, ainda, que a quantidade de dados obtidos de VS com esses verbos foi bastante reduzida.

Diante dessas análises a partir da identificação pelo tipo de sentenças e pelo tipo de verbos, Gravina (2014) chega à seguinte conclusão a respeito das construções com ordem VS no PB: maior ocorrência com o verbo em segunda posição, no entanto, com algum elemento que seja locativo ou adverbial (XVS), em seguida verbo na primeira posição na ordem VS. Em relação à produtividade na língua, a autora afirma que sentenças VOS

13 A sigla EPP, como já mencionado em nota anterior, é decorrente da expressão do inglês Extended Projection Principle. 
possuem maior ocorrência que VS ou OVS. Dessa forma, as análises de Gravina (2014) nos fazem concluir, com base em Pilati (2006), que já no século XIX era possível encontrar oração VS como inversão locativa.

\subsection{Síntese do capítulo}

O presente capítulo procurou apresentar as principais características das inversões locativas, especialmente no português brasileiro (PB). A fim de subsidiar o estudo, primeiramente foram apresentadas as considerações de Levin \& Rappaport (1995) a respeito do assunto. Em seguida, foram apresentadas, uma a uma, as propostas de Pilati (2002), de Pilati (2006), de Corr (2012) e de Gravina (2014).

Levin \& Rappaport (1995), como visto, defendem que as características das inversões locativas do inglês são as seguintes: (i) são orações apresentativas num sentido mais amplo, ou seja, inserem o termo menos familiar, que não precisa ser necessariamente novo na situação do discurso; (ii) apresentam a ordem PP VP NP; (iii) contêm PP locativo ou direcional; (iv) ocorrem tipicamente com verbos inergativos ou inacusativos; (v) possuem verbos informacionalmente leves; e (vi) contêm sujeitos desagentivizados. Os autores afirmam, ainda, que os verbos transitivos apenas são permitidos quando formam estruturas fixas, como take place e take root.

Pilati (2002) e Pilati (2006), como exposto, defendem que, no PB, o fato de haver sempre um $X$ (manifesto ou nulo) à esquerda do verbo faz com que orações na ordem VS se pareçam inversões locativas. Pilati (2002) e Pilati (2006) afirmam que orações com ordem VS:

(i) não são usadas em contextos de respostas a perguntas $Q u$ com foco estreito, ocorrendo, portanto, em contextos de foco largo:

(Ex 1) A: Quem dormiu / Quem comeu o bolo?

$\mathrm{B}_{1}$ : Foi a Bruna (que dormiu / que comeu o bolo).

$\mathrm{B}_{2}$ : A Bruna.

$\mathrm{B}_{3}: *$ Dormiu a Bruna / *Comeu o bolo a Bruna.

(ii) são licenciadas com mais frequência com verbos inacusativos, como atesta a maioria dos estudos variacionistas (cf. Lira, 1986; Berlinck, 1989; Pezatti, 1993; Coelho, 2000; Alberton, 2001); 
(iii) podem ocorrer, no entanto, com verbos inergativos e transitivos, como defendido por Votre \& Naro (1999) e atestado por Pilati (2002) e por Scherre, Naro \& Cardoso (2007):

(Ex 2) a. Toma posse o deputado.

b. Tem a palavra a Senadora Heloisa Helena.

c. Merece destaque a nova seção deste jornal.

[Pilati, 2002]

(Ex 3) Só valem as garotas.

[Scherre, Naro \& Cardoso, 2007]

Pilati (2006) - que segue a análise descritiva de Pinto (1997) para o Italiano propõe que as orações com ordem VS do PB: a) são tipos de inversão locativa e b) apresentam um elemento de natureza locativa, em posição pré-verbal (se nulo, identificado como um

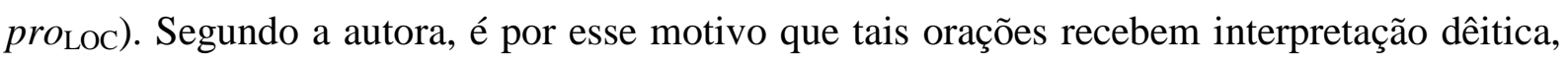
como representado pelo contraste abaixo (dados extraídos de Pilati 2006, p. 199):

(Ex 4) a. A Mary chegou. (em algum outro lugar)

b. Chegou a Mary. (nesse momento / aqui / nesse lugar)

[Pilati, 2006]

Corr (2012), por sua vez, defende que VS nas línguas românicas analisadas não pode ser consequência do Parâmetro do Sujeito Nulo, uma vez que há VS em PB, uma língua de Sujeito Nulo Parcial. Como visto, a autora segue Pinto (1997) e afirma que a ordem VS nessas línguas corresponde a casos de inversões locativas, nas quais um elemento LOC está sintaticamente presente e satisfaz o EPP de T. Para Corr (2012), a alternância entre SV e VS é relacionada à disponibilidade e à seleção de um elemento LOC. Para a autora, VS é um fenômeno lexicalmente condicionado e que não tem relação forte com a divisão entre verbos inacusativos e inergativos (embora haja certa correspondência).

Gravina (2014), por fim, estudou a relação entre sujeito nulo parcial e inversão do sujeito em relação ao verbo, particularmente na diacronia. Para subsidiar sua pesquisa, a autora faz durante todo o seu trabalho um estudo comparativo-diacrônico (séculos XIX e XX) entre o português brasileiro (PB) e o português europeu (PE). A partir da identificação pelo 
tipo de sentenças e pelo tipo de verbo, Gravina (2014) chega às seguintes conclusões a respeito das construções com ordem VS no PB:

(i) verbos monargumentais (inacusativos e inergativos) tinham as situações mais esperadas: enquanto os verbos inacusativos favoreciam um maior uso da inversão do sujeito por selecionarem apenas argumentos internos, os verbos inergativos apresentavam altos índices de ordem SV, tanto no PB, quanto no PE.

(Ex 5) Mas cresce cada vez mais a admiração. (Recreador1, 1845)

[Gravina, 2014]

(ii) maior ocorrência com o verbo em segunda posição, principalmente com verbos inacusativos, no entanto com algum elemento que fosse locativo ou adverbial (XVS).

(Ex 6) $\mathrm{I}^{\mathrm{o}}$ de abril mandou El-rei, que se cunhasse em Minas moeda de prata, e cobrei provincial (Recreador1, 1845)

[Gravina, 2014]

(iii) sentenças VOS, com objeto menos referencial e com sujeito não focalizado, possuíam maior ocorrência que VS ou OVS.

(Ex 7) Destilan Liberdades os ares (Tribuna, 1946)

[Gravina, 2014]

Com base em Gravina (2014), é possível concluir que, desde o século XIX, no PB já havia ocorrência de inversão locativa.

No próximo capítulo, procurar-se-á descrever os contextos de licenciamento da ordem (X)VS, com X manifesto ou nulo. Procurar-se-á, também, defender - de maneira sumária, já que o objetivo central desta dissertação diz respeito ao aspecto quantitativo - dois argumentos: (i) o de que, já no século XIX, no centro-oeste brasileiro, as orações na ordem verbo-sujeito (VS) poderiam ser inversão locativa, como defende Pilati (2006) para os dados do português brasileiro (PB) atual; e (ii) o de que não há relação entre ordem VS e parâmetro pro-drop, como defende Corr (2012). 


\section{CAPÍtULO 3}

\section{ANÁLISE DA ORDEM VS NO CENTRO-OESTE BRASILEIRO NO SÉCULO XIX}

\subsection{Introdução}

O presente capítulo tem por objetivo apresentar os resultados das análises quantitativas efetuadas no corpus escrito do Jornal Matutina Meyapontense sobre as orações na ordem $(\mathrm{X}) \mathrm{VS}$, com X manifesto ou nulo. Em relação ao aspecto qualitativo, defende-se neste capítulo - de maneira sumária, já que o objetivo central desta dissertação diz respeito ao aspecto quantitativo - dois argumentos: (i) o de que, já no século XIX, no centro-oeste brasileiro, as orações na ordem verbo-sujeito (VS) poderiam ser inversão locativa, como defende Pilati (2006) para os dados do português brasileiro (PB) atual; e (ii) o de que não há relação entre ordem VS e parâmetro pro-drop, como defende Corr (2012).

Inicialmente, serão apresentadas informações sobre a constituição da língua no centro-oeste brasileiro até o século XIX. Em seguida, serão apresentados os detalhes sobre o corpus deste trabalho, juntamente com a metodologia utilizada nos dados obtidos. Após essa abordagem, serão apresentadas as análises quantitativas efetuadas no corpus obtido. Por fim, serão defendidos os dois argumentos explicitados no parágrafo anterior.

\subsection{Contato de línguas no centro-oeste brasileiro}

O estudo do contato de línguas no centro-oeste brasileiro deve partir, primeiramente, da análise do Tratado de Tordesilhas, a fim de facilitar o entendimento da formação do processo linguístico na região. Em seguida, faz-se necessário mostrar a ação dos bandeirantes paulistas na incorporação de terras espanholas aos domínios portugueses, o surgimento da Capitania de Goiás e, por fim, o descobrimento de ouro no centro brasileiro.

Segundo Chaim (1974), o Tratado de Tordesilhas foi um acordo celebrado entre as Coroas espanhola e portuguesa, em 1494, que disciplinava o domínio do chamado Novo Mundo. Esse pacto estabelecia que as terras situadas a oeste de uma linha imaginária pertenceriam aos espanhóis e as que estavam a leste, aos portugueses. Se nos dias atuais, essa fronteira estaria limitada ao norte em Belém-PA e ao sul em Laguma-SC. 
Diante dos limites estabelecidos pelo Tratado, o território pertencente ao atual Estado do Goiás ficaria situado em sua maior parte em terras que seriam espanholas. Entretanto, Chaim (1974) revela que, no início do século XVIII, os bandeirantes paulistas incorporaram essas terras aos domínios portugueses, o que foi posteriormente ratificado pelo Tratado de Madri.

Em 1749, esse terreno - que, desde a ação dos bandeirantes paulistas até esse ano, esteve inserido à Capitania de São Paulo - tornou-se uma capitania independente. Segundo Chaim (1974), a sua área correspondia aproximadamente ao atual território do Estado de Goiás - exceto em relação ao Triângulo Mineiro, que perderia para Minas Gerais, e ao Rio das Mortes, hoje pertencente ao Mato Grosso. Cabe destacar também uma outra exceção, que, por razão lógico-temporal, a autora não citou, qual seja o Tocantins, desmembrado em 1988 do norte de Goiás.

Durante muito tempo essas terras ficaram esquecidas. Porém, quando, na segunda metade do século XVIII, descobriu-se ouro no local, a Capitania de Goiás tornou-se alvo de uma forte imigração. Chaim (1974) relata que os garimpeiros e exploradores encontraram a região povoada por "um sem número de grupos tribais pacíficos e hostis, que a cada instante embargavam-lhes os passos". Repetia-se nesse espaço o processo ocorrido em muitos locais do Brasil no período da colonização: ocupação das terras indígenas; escravização dos grupos mais pacíficos; e choques periódicos com os hostis, sejam culturais, sejam linguísticos.

O descobrimento do ouro, bem como a expansão do bandeirismo e a catequese jesuítica, estabeleceu uma rota de penetração na região central do Brasil. Porém, conforme Palacin (1972), esses ingressos não se constituíram na colonização daquele espaço; eram apenas incursões de reconhecimento das possibilidades econômicas da região, por meio da coleta de ouro e de aprisionamento de índios. Daí se observa o contato de línguas entre os exploradores e os povos indígenas que habitavam a região.

Cabe, por ora, analisar os choques linguísticos entre os "brancos", com a sua Língua Geral Paulista, e os nativos daquela região, através de seus mais variados falares.

\subsubsection{Língua Geral Paulista}

A expressão "língua geral" foi inicialmente usada pelos portugueses e espanhóis para qualificar línguas indígenas de grande difusão numa área. Posteriormente, foi conceituada, segundo Rodrigues (1994), como uma "língua popular, geral a índios missionados e aculturados e a não-índios”. 
Segundo Rodrigues (1996), o início da formação dessa Língua Geral data de 1532, com a fundação da vila de São Vicente por Martim Afonso de Souza e a consequente colonização da região Sudeste do Brasil, em pleno domínio tupi. O autor destaca, entretanto, que, antes dessa data, já havia portugueses estabelecidos entre esses povos.

O grupo de colonos trazidos por Martim Afonso de Souza para São Vicente era composto exclusivamente por homens, sendo que, somente em 1537, chegou o primeiro casal português a São Vicente. Mas, mesmo com a chegada de outros casais, o afluxo maior de colonos portugueses continuou sendo de homens sós, que passavam a viver com mulheres indígenas (RODRIGUES, 1996, p. 96).

Essa situação fez com que surgisse uma população mestiça cuja língua materna era o tupi das mães e também de todos os parentes maternos, já que do lado dos pais normalmente não havia parentes consanguíneos. Por muito tempo falou-se a língua dos tupis, em que, segundo Antônio Vieira:

...ainda nesse fim do século XVII é certo que as famílias dos Portugueses e Índios de São Paulo estão tão ligadas hoje umas com as outras, que as mulheres e os filhos se criam mística e domesticamente,e a língua que nas ditas famílias se fala é a dos índios, e a portuguesa a vão os meninos aprender à escola...

(VIEIRA, 1951, p. 355 apud RODRIGUES, 1996)

Com o passar dos anos, essa colonização trouxe como efeito o extermínio dos índios tupis de São Paulo. A língua, dessa forma, passou a reproduzir-se essencialmente como idioma dos mestiços, mesmo quando já não havia indígenas (não-mestiços) nas famílias. A situação linguística dos portugueses casados com mamelucas era basicamente a mesma das famílias constituídas por mamelucos e mamelucas: falava-se correntemente a língua geral, e apenas o marido e, a partir de certa idade, os filhos homens eram bilíngues em português. Borges (2008) observa que a língua que falavam os paulistas já não mais servia a uma restrita sociedade indígena, mas à sociedade dos mamelucos.

Essa língua, generalizada na população paulista de meados do século XVII a meados do século XVIII, chamou-se, em São Paulo, de Língua Geral Paulista, sendo usada pelos bandeirantes que saíam de lá para explorar as terras que hoje correspondem a Minas Gerais, Goiás, Mato Grosso e Paraná. De acordo com Rodrigues (1994), por ser a língua desses pioneiros, penetrou essa Língua Geral em áreas onde nunca tinham chegado índios Tupi-Guarani, deixando sua marca no vocabulário popular e na toponímia das regiões exploradas. 


\subsubsection{Línguas indígenas}

Segundo Chaim (1974), as tribos indígenas encontradas em Goiás, à época das entradas e bandeiras, eram as dos Akroá, Amadu, Apinayé, Araé, Araxá, Canoeiro, Crayá, Crixá, Goya, Gradaú, Karajá, Kayapó, Kururu, Mangariruba, Tapirapé, Temesseu, Xacriabá, Xavante e Xerente. Esses índios eram falantes de línguas indígenas dos troncos linguísticos Tupi e Macro-Jê. Borges (2008) relata que não se têm dados muito consistentes a respeito de todas essas línguas, pois o tronco Macro-Jê é ainda hipotético.

A atitude dos jesuítas e de outras ordens missionárias foi dúbia em relação à questão indígena. Se de um lado se posicionavam contra a escravização indígena, por outro os confinavam nos chamados aldeamentos cristãos, onde, através da catequese, obrigavam esses povos a abandonar seu modo tradicional de vida, suas andanças pela mata, suas lideranças, substituindo suas crenças e cerimônias pelos ritos católicos. Confinados em populosos aldeamentos, os indígenas estavam sujeitos com mais frequência às doenças trazidas pelos brancos, como foi o caso de repetidas epidemias de varíola. Em 1562, Anchieta escreveu que 30 mil índios haviam morrido em menos de 3 meses, em decorrência de doença (CHAIM, 1974, p. 56).

A alta mortandade exigia a reposição contínua dos indígenas que trabalhavam para os padres e, temporariamente, para os colonos. Os missionários adotaram uma forma de atração denominada "descimento". Eles seguiam para o interior e atraíam os indígenas, após convencê-los de que era melhor ficar nos aldeamentos, onde eles estariam ao abrigo dos colonos portugueses e onde se tornariam cristãos e alcançariam o céu.

Segundo Rodrigues (1994), os indígenas aldeados não se tornavam escravos, mas perdiam suas tradições e eram assimilados à sociedade colonial, tornando-se, muitas vezes, aliados importantes dos portugueses, não só na repressão contra os escravos negros, mas, também, contra nações indígenas inimigas. Alguns grupos conseguiam voltar à antiga vida, mas a maioria se integrava, facilitando a mestiçagem que tanto marcou o povo brasileiro.

\subsubsection{Línguas africanas}

Iniciado o tráfico entre Brasil e África, já na primeira metade do século XVI, observou-se a confluência de línguas africanas com o português europeu antigo. A consequência direta desse contato linguístico e cultural foi a alteração da língua portuguesa na colônia sul-americana e a subsequente participação de falantes africanos na construção da modalidade da língua e da cultura representativas do Brasil (CASTRO, 200?, p. 4). 
Enquanto o século XVII e o início do século XVIII representaram uma etapa de reconhecimento e de análise das possíveis explorações econômicas da região Centro-Oeste, no final do século XVIII e no século XIX estabeleceu-se a efetiva ocupação da região por meio da mineração, o que proporcionou o contato entre diversas línguas indígenas, de escravos e a língua portuguesa do europeu (BORGES, 2008, p. 34).

O descobrimento do ouro fez com que o homem se fixasse ao território goiano, lançando as bases da colonização portuguesa. A região passou a funcionar como fornecedora de metais preciosos à metrópole, elevando, dessa forma, o afluxo de pessoas.

Segundo Mattos e Silva (2004), o contingente populacional goiano no final do século XVIII (72.657 habitantes) era elevado, o qual ultrapassava em mais de vinte mil o número de habitantes da cidade de São Paulo (52.206). Contribuiu para esse resultado, além do contingente de índios $(29.622,41 \%)$, tanto nativos quanto oriundos da migração litorânea, o considerável número de negros escravos $(34.104,47 \%)$, que, de regra, vinham acompanhar seus senhores na corrida pelo ouro.

Castro (2001) ressalta que, entre os povos trazidos da África para a região, destacam-se, pela superioridade numérica, os povos da família linguística banto e kwa, ambos de grupos linguísticos sub-saarianos. Entre os bantos, destacam-se, pela duração e continuidade no tempo de contato direto com o colonizador português, três povos: a) bacongo, falantes da língua quicongo, provenientes dos atuais Congo, Gabão, Zaire e Angola; b) ambundo, falantes de quimbundo, concentrados principalmente em Angola; c) ovimbundo, falantes de umbumdo, localizados numa região da costa oeste africana.

Em mais de três séculos de escravidão no Brasil, essas línguas africanas influenciaram a língua portuguesa em certos aspectos. De acordo com Castro (2001), no léxico, verificam-se palavras africanas incorporadas pelo português (samba, xingar, muamba, tanga, sunga, jiló, maxixe, berimbau, capanga, banguela, cachaça, cachimbo, fubá, gogó, mocotó, cuíca etc). Na fonologia, o sistema de sete vogais orais e a estrutura silábica (CV.CV) (consoante vogal.consoante vogal) do português são semelhantes às das línguas africanas. Esse tipo de aproximação casual, mas notável, provavelmente possibilitou a continuidade do tipo prosódico de base vocálica do português antigo na modalidade brasileira, afastando-a, portanto, do PE, de pronúncia mais consonantal (BORGES, 2008, pp. 38-39).

\subsubsection{Isolamento linguístico}

De acordo com Borges (2008), a partir do século XIX, a população da região Centro-Oeste foi reduzida progressivamente, em consequência de determinados fatores 
econômicos, como, por exemplo, a ausência de novas descobertas de minas de ouro. Em decorrência disso, houve uma redução da quantidade de escravos, que levaram suas línguas para outros locais do Brasil onde ainda havia extração aurífera.

Observa-se, desse modo, que um novo tipo de povoamento se estabeleceu a partir do final do século XVIII, sobretudo no sul da capitania, onde campos de pastagens naturais se transformaram em centros de criação. Borges (2008) destaca que para tal expansão houve a necessidade de tomar dos índios as áreas sob seu domínio, o que acarretou o quase total desaparecimento dos falantes das línguas ameríndias.

Com o fim da mineração e com o extermínio dos indígenas, houve a cessação do fluxo de bandeirantes, e sua Língua Geral Paulista, para a região, pois esses foram buscar ouro e índios em outras localidades. Porém, em meados do século XIX, um novo tipo de povoamento do Centro-Oeste foi estabelecido através de duas vias de penetração na região: a de "cima", originária da região Nordeste, com criadores de gado que se espalharam pelo oeste da Bahia, através do rio São Francisco, penetrando nas fronteiras de Goiás; e a de "baixo", originária de São Paulo, de Minas Gerais e da região Sul, que penetrou no território goiano através dos antigos caminhos da mineração, estabilizando-se no Sudoeste da capitania. (BORGES, 2008, pp. 35-36).

Além disso, a dificuldade de comunicação com as outras regiões brasileiras refletiu negativamente sobre o fluxo migratório na região. Borges (2008) afirma que, devido às enormes distâncias que separavam a província dos portos do litoral e à sua pobreza para construir vias de acesso à região, Goiás e sua comunidade linguística ficaram relativamente isoladas do restante do país.

Esse isolamento linguístico - após uma grande movimentação populacional e, consequentemente, linguística - torna instigante a realização de um estudo acerca da língua portuguesa produzida na região, como já observado por Borges, Salles \& Pilati (2012). Assim, constituiu-se um corpus que retrata essa língua, em particular, a ordem verbo-sujeito (VS).

\subsection{Constituição do corpus}

Após a discussão sobre o contato de línguas no centro-oeste brasileiro, apresenta-se, nesta seção, a explicação do processo de construção do corpus desta dissertação. A fonte dos dados deste trabalho é exclusivamente o Jornal Matutina Meyapontense.

Segundo Carvalho (2000), o processo de formação do Jornal Matutina Meyapontense começou em 1829, quando o comendador Joaquim Alves de Oliveira adquiriu no Rio de Janeiro uma oficina tipográfica e trouxe-a para Meya Ponte (atual Pirenópolis-GO). 
A partir dessa data, segundo o autor, fundou-se a Typografia de Oliveira, publicando-se, em 5 de março de 1830, o primeiro jornal da região Centro-Oeste do Brasil e o primeiro a ser publicado fora de uma capital.

As características do Jornal Matutina Meyapontense, de acordo com Carvalho (2000), eram consideradas liberais para os moldes da época. O Jornal publicava notícias defendendo os direitos humanos, a ética e a cidadania; recebia cartas com codinomes e publicava-as na íntegra; e trazia em suas edições anedotas de cunho liberal. Carvalho (2000) expõe, ainda, que o Matutina Meyapontense, um marco na imprensa nacional, circulou de 5 de março de 1830 a 24 de maio de 1834, totalizando 526 edições. O autor destaca que - com humor, liberdade e seriedade - o Jornal deixou para a sociedade um legado histórico marcante do Brasil Central imperialista e distante dos grandes centros.

Para a constituição do corpus desta dissertação, analisaram-se as cartas de leitores (seção "Correspondencia") publicadas nas edições de $n^{\circ} 1$ (5 de março de 1830) a $n^{\circ}$ 54 (11 de maio de 1830) do referido Jornal. Escolheu-se essa seção objetivando retratar com a maior fidelidade possível as normas vernáculas do português na região centro-oeste brasileira, no século XIX, e, assim, realizar uma abordagem quantitativa autêntica e natural das orações com ordem VS e/ou das inversões locativas.

Utilizando-se a categorização de Sardinha (2000), o corpus utilizado neste artigo pode ser classificado como: (a) quanto ao modo: escrito; (b) quanto ao tempo: histórico; (c) quanto ao conteúdo: especializado, em virtude de ter como foco apenas um único gênero, qual seja carta de leitor; e regional ou dialetal, visto serem os textos constituintes de uma variedade sociolinguística específica; (d) quanto à autoria, de língua nativa; e (e) quanto à finalidade, de estudo.

\subsection{Metodologia da apresentação dos dados}

Neste capítulo, como mencionado inicialmente, faz-se uma análise descritiva das orações com ordem verbo-sujeito (VS) e/ou das inversões locativas encontradas no português do centro-oeste brasileiro no século XIX. Para que se acompanhe com maior facilidade a apresentação dos resultados, explicar-se-á nesta seção a metodologia adotada na análise das 61 sentenças que compõem o corpus deste trabalho.

Como o objetivo central desta dissertação é apresentar uma análise quantitativa dos dados que compõem o corpus deste estudo, considerar-se-á, até o momento oportuno de análise neste trabalho, que muitas das orações declarativas em períodos simples na ordem VS que compõem o corpus podem ser consideradas inversões locativas (cf. Pilati, 2006). 
Para entender como se comportavam as orações VS no português do centrooeste brasileiro no século XIX, optou-se, com base em Gravina $(2014)^{14}$, por fazer uma classificação a partir de dois grupos: (i) pela construção sentencial parentética; e (ii) pelo tipo de verbo. Dessa forma, a classificação genérica para a análise dos dados ficou da seguinte forma: ${ }^{15}$

(i) Orações parentéticas;

(ii) Orações com verbos transitivos;

(iii) Orações com verbos inacusativos;

(iv) Orações com verbos ser/estar;

(v) Orações com verbos inergativos.

Cada sentença do corpus desta dissertação foi classificada de acordo com um dos parâmetros elencados de (i) a (v). Após essa classificação, obteve-se a seguinte tabela, na qual se considerou até duas casas decimais para os valores percentuais:

\section{Tabela 15 - Número total da distribuição de cada contexto selecionado de VS para análise no Jornal Matutina Meyapontense}

(Século XIX - 1830)

\begin{tabular}{cccccc}
\hline & Parentética & Transitivo & Inacusativo & Estar/Ficar & Inergativo \\
\hline \multirow{2}{*}{ VS } & $8 / 61$ & $28 / 61$ & $16 / 61$ & $9 / 61$ & $0 / 61$ \\
& $13,11 \%$ & $45,90 \%$ & $26,22 \%$ & $14,75 \%$ & $0 \%$ \\
\hline
\end{tabular}

Diante da análise dessa tabela, percebeu-se que havia um complexo conjunto de informações, o qual necessitava ser averiguado com cautela para que se mapeassem as orações VS no português do centro-oeste brasileiro no século XIX. Desse modo, a fim de um maior detalhamento da classificação das orações VS e das inversões locativas, procurou-se investigar a natureza do elemento que antecedia a estrutura VS nas orações classificadas pelo

14 Conforme visto no capítulo 2 desta dissertação, Gravina (2014) defende que apenas as orações com verbos inacusativos é que podiam ser consideradas inversões locativas - ao contrário de Pilati (2006), que defende que, atualmente, todas as orações declarativas do português brasileiro na ordem verbo-sujeito são inversões locativas.

15 Nesta dissertação, optou-se por não coletar dados de inversão em orações interrogativas. Isso porque se pretendeu analisar os dados do corpus obtido de acordo com Pilati (2006), que analisa as inversões apenas em orações declarativas. Dessa forma, diferentemente de Gravina (2014), não constará nas tabelas desta dissertação o parâmetro "Interrogativa". 
tipo de verbo. Assim, foram somados àqueles cinco parâmetros já mencionados outros quatro novos parâmetros, quais sejam:
(i) Elemento manifesto (adjunto adverbial);
(ii) Possível locativo nulo;
(iii) Pronome relativo;
(iv) Conjunção.

Após a classificação dos dados que compõem o corpus desta dissertação pela análise conjunta do tipo de verbo e da natureza do elemento que precede VS, obteve-se a seguinte tabela, na qual se considerou até duas casas decimais para os valores percentuais: ${ }^{16}$

\section{Tabela 16 - Total de inversões locativas obtido pela análise conjunta do tipo de verbo e da natureza do elemento que precedia VS}

\begin{tabular}{ccccc}
\hline$X$ & $\begin{array}{c}\text { Transitivo } \\
(52,81 \%)\end{array}$ & $\begin{array}{c}\text { Inacusativo } \\
(30,17 \%)\end{array}$ & $\begin{array}{c}\text { Estar/Ficar } \\
(16,96 \%)\end{array}$ & $\begin{array}{c}\text { Inergativo } \\
(0 \%)\end{array}$ \\
\hline $\begin{array}{c}\text { Elemento manifesto } \\
(43,38 \%)\end{array}$ & $9 / 53$ & $10 / 53$ & $4 / 53$ & $0 / 53$ \\
& $16,98 \%$ & $18,86 \%$ & $7,54 \%$ & $0 \%$ \\
Possivel locativo nulo & $8 / 53$ & $2 / 53$ & $1 / 53$ & $0 / 53$ \\
$(20,74 \%)$ & $15,09 \%$ & $3,77 \%$ & $1,88 \%$ & $0 \%$ \\
Pronome relativo & $1 / 53$ & $2 / 53$ & $2 / 53$ & $0 / 53$ \\
$(9,42)$ & $1,88 \%$ & $3,77 \%$ & $3,77 \%$ & $0 \%$ \\
Conjunção & $10 / 53$ & $2 / 53$ & $2 / 53$ & $0 / 53$ \\
$(26,40 \%)$ & $18,86 \%$ & $3,77 \%$ & $3,77 \%$ & $0 \%$ \\
\hline
\end{tabular}

Para complementar a análise dos dados de orações na ordem VS no português do centro-oeste brasileiro no século XIX, procurou-se também analisar a ordem dos elementos de cada uma das sentenças que compõe o corpus desta dissertação. Assim, verificou-se a ordem dos elementos nas orações VS com verbos transitivos, com verbos inacusativos e com os verbos ser/estar, bem como nas orações parentéticas. Destaque-se que essa análise não foi realizada com verbos inergativos, em razão de o corpus deste trabalho não possuir dados com esse tipo de verbo.

16 Em razão dessa análise não envolver as construções sentenciais parentéticas, o número total dos dados que compunham o corpus passou, nessa análise, de 61 para 53. 
Por fim, cabe destacar que os dados serão apresentados seguidos pela sigla "MM", que corresponde ao Jornal Matutina Meyapontense, da edição e do número da página de que a oração VS foi extraída. Acrescente-se, ainda, que, em algumas classificações, inserirse-á a ordem dos elementos de cada construção. Além disso, para fins de esclarecimento, os dados serão expostos de acordo com a seguinte notação:

- $\quad$ elemento que precede o sujeito $(\mathrm{X})$ : negrito

- verbo (V): itálico

- $\quad$ sujeito (S): sublinhado

- $\quad$ objeto $(\mathrm{O})$ : subscrito

Na próxima seção, será apresentada detalhadamente a análise descritiva das orações VS encontradas no corpus desta dissertação.

\subsection{Análise descritiva dos dados}

Na seção anterior, mostrou-se que os dados serão analisados de acordo com três classificações: (i) pela construção sentencial parentética e pelo tipo de verbo; (ii) pela relação entre o tipo de verbo e a natureza do elemento que precede VS; e (iii) pela ordem dos elementos.

Como observado, a classificação que melhor contempla, frise-se, todos os dados do corpus é a que realiza a análise pela construção sentencial parentética e pelo tipo de verbo. Dessa forma, para melhor organização deste trabalho, esta seção será subdividida levando-se em consideração essa classificação: (i) orações parentéticas; (ii) orações com verbos transitivos; (iii) orações com verbos inacusativos; (iv) orações com verbos ser/estar; e (v) orações com verbos inergativos.

As outras duas classificações serão analisadas dentro de cada um dos cinco parâmetros dessa classificação mais abrangente. Destaque-se que essas duas classificações apenas serão analisadas quando for cabível.

\subsubsection{Ordem VS em orações parentéticas}

As orações parentéticas são aquelas em que os verbos se encontram em contextos de referência a algo que se havia "dito", "falado", "pensado", "respondido", 
"perguntado", ou algo nesse sentido. Essas orações também foram conceituadas em Pedroza (2010) como orações com verbo dizer. ${ }^{17}$

No corpus formado pela análise do Jornal Matutina Meyapontense (MM), estão presentes 8 construções parentéticas na ordem verbo-sujeito (VS), as quais estão dispostas a seguir:

(63) a. Diz S. Ex. n'aquella circular - que o primeiro dever dos subditos (...).

(MM, Edição 12, p. 3)

b. Continuei no exame da questaõ, e li em Natal Alex. Theol. Dogm. e Mor. Tom. $1^{\mathrm{o}} \mathrm{pg}$. 98 - Art. - Communicação dos Santos - que os Santos fazem no Ceo huã, sociedade verdadeira com Deos, diz o Apost. S. Joaõ Ep. 1. C. 1.

(MM, Edição 14, p. 4)

c. A Providencia, disia a pagina que abri quando sendo todos os homes iguaes por natureza, fez huns ricos, e outros pobres (...).

(MM, Edição 15, p. 2)

d. (...) o qual, dizem todos, conservou a mais escrupuloza neutralidade (...).

(MM, Edição 17, p. 3)

e. Matei o Diabo! gritava elle pelas Ruas mui Contente.

(MM, Edição 20, p. 4)

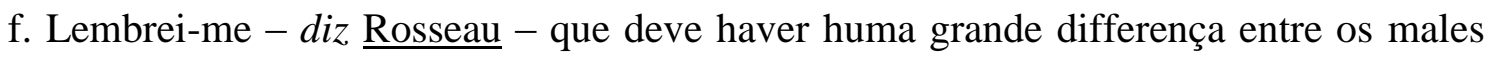
das derradeiras classes da Sociedade, e os que afflingem as primeiras, porque, diz elle, os males do povo saõ effeito da má constituiçaõ da Sociedade (...).

(MM, Edição 25, p. 2)

g. Reparo, Sr. Professor, dise o Sr. Cuiabano, ore contudo (...).

(MM, Edição 31, p. 4)

17 A conceituação de Pedroza (2010) não foi utilizada nesta dissertação em razão de poder gerar alguma dificuldade ao leitor em eventual comparação das análises deste trabalho com as de Gravina (2014). Dessa forma, optou-se por utilizar a nomenclatura empregada por Gravina (2014) para orações com essa configuração. 
h. Esta Reccifa, diz o inco Collega, que cura a falta de educaçaõ, ensina a fallar, e escrever correctamente, extingue a Impostura, a Hipocrisia, e faz homem bom Cidadaõ.

(MP, Edição 31, p. 4)

As 8 sentenças em (63) correspondem a 13,11\% do total dos dados que compõem o corpus deste trabalho, conforme foi exposto na tabela 15. Todas as orações parentéticas do corpus aparecem na ordem VS sem qualquer elemento (X) entre o verbo (V) e o sujeito (S), assim como os resultados de Gravina (2014) para essas construções.

As sentenças em (63) também evidenciam que, imediatamente antes da estrutura VS, não se verifica qualquer elemento manifesto (adjunto adverbial), pronome relativo ou conjunção. Observa-se, ainda, que não é possível a presença de um locativo nulo precedendo VS, já que essas orações apresentam um contexto semântico bastante específico, não sendo consideradas, portanto, inversões locativas.

\subsubsection{Ordem VS com verbos transitivos}

Neste trabalho, classificou-se como verbos transitivos aqueles que selecionam um argumento externo e um ou dois argumentos internos. No corpus formado pela análise do Jornal Matutina Meyapontense (MM), estão presentes 28 orações na ordem VS com verbos transitivos.

Ao analisar as orações com verbos transitivos levando-se em consideração também a natureza do elemento que precedia VS, obteve-se um maior detalhamento dos dados. A partir dessa sistematização, construiu-se a tabela a seguir, na qual se considerou até duas casas decimais para os valores percentuais:

Tabela 17 - Número de orações na ordem VS com verbos transitivos no

Jornal Matutina Meyapontense

(Século XIX - 1830)

\begin{tabular}{ccccc}
\hline \multicolumn{5}{c}{ Elemento que precede VS } \\
& $\begin{array}{c}\text { Elemento manifesto } \\
\text { (Adjunto adverbial) }\end{array}$ & Possivel locativo nulo & Pronome relativo & Conjunção \\
\hline \multirow{2}{*}{ VS } & $9 / 28$ & $8 / 28$ & $1 / 28$ & $10 / 28$ \\
& $32,14 \%$ & $28,57 \%$ & $3,57 \%$ & $35,71 \%$ \\
\hline
\end{tabular}


A tabela 17 evidencia um número de orações na ordem VS com verbos transitivos muito equânime quando o elemento que precedia VS era um adjunto adverbial, ou um possível locativo nulo, ou uma conjunção. Quando o elemento que precedia VS era um pronome relativo, o número de orações na ordem VS, comparado aos outros três casos, era bastante reduzido.

As 9 orações na ordem VS com verbos transitivos em que o elemento que precedia VS era um adjunto adverbial estão dispostas em (64), a seguir. Dessas 9 orações, 5 pareciam apresentar características que as faziam semelhantes a inversões locativas (64a, 64c, $64 \mathrm{~g}, 64 \mathrm{~h}, 64 \mathrm{i})$ :

(64) a. Daqui poderão os chamados Philosophos debaixo do pretexto especioso, más punivel, de instruir o povo, e fazelo melhor, ensinar virtudes perigosas, e das quaes elle naõ deve ter conhecimento. (XVSxvO)

(MM, Edição 4, p. 4)

b. A Autor da Demanda he hum mizeravel, com o Reo nã̃ tem elle amizade. (XVSO)

(MM, Edição 12, p. 3)

c. (...) este exemplo excitou tambem em mim o dezejo de ver transcriptas na sua interessante Folha algumas das sabias reflexões, que em Março de 1816 produzio aos Olhos do Publico o Investigador Portuguez em Inglaterra por occaziaõ, da noticia da Elevaçaõ do Brazil á Cathegoria de Reino. (XVOS)

(MM, Edição 11, p. 3)

d. Nisto nã̃ tem agora decerto razaõ os Senhores Eccleziasticos. (XVxOS)

(MM, Edição 13, p. 3)

e. Naõ pude continuar a ler, Senhor Redactor, por vir a noite; pode ser que nã̃ me agradem os pensamentos do tal Turinense como agradaraõ a hum Sexagenario (...). (XOVS)

(MM, Edição 15, p. 3)

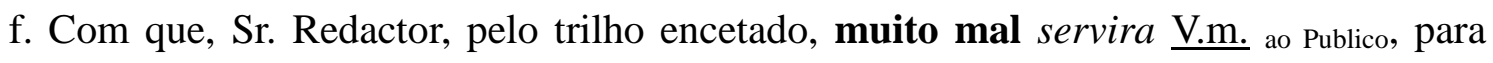
quem, por hora, cuido quer escrever (...). (XVSO)

(MM, Edição 17, p. 2) 
g. Aqui desperdiça o Sr. Zellozo hum Latinorio (...). (XVSO)

(MM, Edição 18, p. 4)

h. (...) e ainda fazem os Parochos illuminados (...). [XVS(O)]

(MM, Edição 18, p. 4)

i. Jamais escapou da sua boca o segredo, e a mentira, e julgou, que a dissimulaçaõ, que se diz necessaria, para Reinar, nunca devia transcender as balisas do silencio. (XVOS)

(MM, Edição 54, p. 3)

As 8 orações na ordem VS com verbos transitivos em que o elemento que precedia VS era um elemento nulo estão dispostas em (65), a seguir. Conforme foram expostas as características das inversões locativas no capítulo 2, a sentença em (65a) parecia ser uma caso de inversão locativa.

(65) a. Ignora o Sr. Redactor o facto do Rebouças, de que fui testemunha ocular (...). [(X)VSO]

(MM, Edição 17, p. 3)

b. (...) parece mais hum pedante visioneiro, do que intrigante, tanta compaixão merece sua correspondencia, como a resposta. [(X)OVS]

(MM, Edição 17, p. 4)

c. (...) e possuindo-se os Periodicos de todo o Imperio, como se espera antes de 3 mezes, apresentará ella objectos mais interessantes. [(X)VSO]

(MM, Edição 17, p. 5)

d. Fez o sancto Abbade huma pratica, o hum Sermao (...). [(X)VSO]

(MM, Edição 20, p. 4)

e. E reunindo-se no día 24 de Abril do corrente os Cidadaons amigos desta salutar instituiçaõ e os Officiaes de todos os Quarteiroens desta Cidade para assistirem a sua primeira Audiencia, aproveitou-se elle de taõ opportuna occasiaõ para persuadir a estes ultimos o exacto cumprimento de suas obrigaçoens (...). [(X)VSO] (MM, Edição 26, p. 3) 
f. Naõ desejo comtudo, que vós exponhaes a perder dinheiro consideravel, lembrado do que ${ }_{\text {me }}$ disse hotem hum meo Amigo (...). [(X)OVXS]

(MM, Edição 33, p. 4)

g. Achando-se em Concurso as Cadeiras de Philosophia Racional, e Moral da Cidade de Cuiabá, e a de Gramatica Latina da Villa do Alto Paraguay Diamantina requereraõ Antonio Luiz Patricio da Silva Manso, e Braz Pereira Mendes exames (...). $[(\mathrm{X}) \mathrm{VSO}]$

(MM, Edição 34, p. 4)

h. (...) e seguindo Manso para a Corte, preferio o Sr. Braz a residencia da Cidade a do Diamantino, e pedindo Demissaõ da Cadeira, requereo a de Philosophia (...). [(X)VSO]

(MM, Edição 34, p. 4)

A oração na ordem VS com verbo transitivo em que o elemento que precedia VS era um pronome relativo está disposta em (66), a seguir:

(66) (...) entaõ desejaria que se fisessem jurar os Litigantes, como fasia Licinio Nepos por orde do Senado, se tinhaõ dado dinheiro adiantado para serem castigados os Letrados (...). $[\mathrm{XVS}(\mathrm{O})]$

(MM, Edição 22, p. 4)

As 10 orações na ordem VS com verbos transitivos em que o elemento que precedia VS era uma conjunção estão dispostas em (67), a seguir:

(67) a. (...) e naõ nos entregarmos a remedios, como ensina õ os Sabios de outros Paizes. $[\mathrm{XVS}(\mathrm{O})]$

(MM, Edição 4, p. 4)

b. A Imprensa he o alto pelourinho, como the chama o Abbade de Pradt (...). (XOVS)

(MM, Edição 11, p. 3) 
c. (...) e formã̃ todos hum Corpo (...). (XVSO)

(MM, Edição 14, p. 4)

d. (...) comtudo todos saõ bons, e perfeitos e recebe cada hum o gozo que the pertence. (XVSO)

(MM, Edição 14, p. 4)

e. (...) e possuindo a Bahia homens de tantos Creditos literarios (...). (XVSO)

(MM, Edição 17, p. 6)

f. Que Homilia, como faziaõ os antigos Padres da Igreja (...). [XVS(O)]

(MM, Edição 18, p. 4)

g. (...) entaõ desejaria que se fisessem jurar os Litigantes, como fasia Licinio Nepos por orde do Senado, se tinhaõ dado dinheiro adiantado para serem castigados os Letrados (...). [XVS(O)]

(MM, Edição 22, p. 4)

h. (...) e sendo huma verdade que elle he já luminoso, como disse o seo Correspondente S. de R. F. promette ainda para o futuro hum argumento de vantagens verdadeiramente reaes, como nos indica a sua Epigraphe. (XOVS)

(MM, Edição 26, p. 3)

i. (...) e sendo huma verdade que elle he já luminoso, como disse o seo Correspondente S. de R. F. promette ainda para o futuro hum argumento de vantagens verdadeiramente reaes, como nos indica a sua Epigraphe. [XVS(O)]

(MM, Edição 26, p. 3)

j. (...) e por conseguinte convem a observancia dos Mandamentos dos Brasileiros, que como diz a Astréa se encerraõ em dous - Uniaõ e Olho vivo (...). [XVS(O)]

(MM, Edição 27, p. 4) 
Os 28 dados mostram, na maioria das vezes, a presença de algum elemento que antecede a estrutura VS. A natureza desses elementos, como se pode observar, era sempre de um adjunto adverbial, ou de um pronome relativo ou de uma conjunção.

Ademais, os 28 dados permitem também que se analise a ordem dos elementos que integram cada oração na ordem VS com verbos transitivos. Para uma melhor visualização da ordem desses elementos, elaborou-se a tabela a seguir, com a quantidade de cada ordem, em que se considerou até duas casas decimais para os valores percentuais:

\section{Tabela 18 - Ordem dos elementos em orações VS com verbos transitivos no Jornal Matutina Meyapontense (Século XIX - 1830) ${ }^{18}$}

\begin{tabular}{|c|c|c|c|c|c|c|c|c|c|c|}
\hline \multirow[b]{2}{*}{$X$} & \multicolumn{6}{|c|}{ Contiguidade (VS) } & \multicolumn{4}{|c|}{ Não-contiguidade $(V-S)$} \\
\hline & $X V S O$ & $(X) V S O$ & XOVS & $(X) O V S$ & $X V S(O)$ & $X V S V O$ & XVOS & $(X) \operatorname{VOS}$ & $(X) O V x S$ & $X V x O S$ \\
\hline Adjunto adverbial & $\begin{array}{c}3 / 9 \\
33,33 \%\end{array}$ & - & $\begin{array}{c}1 / 9 \\
11,11 \%\end{array}$ & - & $\begin{array}{c}1 / 9 \\
11,11 \%\end{array}$ & $\begin{array}{c}1 / 9 \\
11,11 \%\end{array}$ & $\begin{array}{c}2 / 9 \\
22,22 \%\end{array}$ & - & - & $\begin{array}{c}1 / 9 \\
11,11 \%\end{array}$ \\
\hline Possivel locativo nulo & - & $\begin{array}{c}6 / 8 \\
75 \%\end{array}$ & - & $\begin{array}{c}1 / 8 \\
12,5 \%\end{array}$ & - & - & - & $\begin{array}{l}0 / 8 \\
0 \%\end{array}$ & $\begin{array}{c}1 / 8 \\
12,5 \%\end{array}$ & - \\
\hline Pronome relativo & $\begin{array}{l}0 / 1 \\
0 \%\end{array}$ & - & $\begin{array}{l}0 / 1 \\
0 \%\end{array}$ & - & $\begin{array}{c}1 / 1 \\
100 \%\end{array}$ & $\begin{array}{l}0 / 1 \\
0 \%\end{array}$ & $\begin{array}{l}0 / 1 \\
0 \%\end{array}$ & - & - & $\begin{array}{l}0 / 1 \\
0 \%\end{array}$ \\
\hline Conjunção & $\begin{array}{l}3 / 10 \\
30 \%\end{array}$ & - & $\begin{array}{l}2 / 10 \\
20 \%\end{array}$ & - & $\begin{array}{l}5 / 10 \\
50 \%\end{array}$ & $\begin{array}{c}0 / 10 \\
0 \%\end{array}$ & $\begin{array}{c}0 / 10 \\
0 \%\end{array}$ & - & - & $\begin{array}{c}0 / 10 \\
0 \%\end{array}$ \\
\hline
\end{tabular}

A tabela 18 sistematiza o que se encontrou nos dados sobre a ordem dos elementos em orações VS com verbos transitivos no Jornal Matutina Meyapontense. A partir da observação dos dados numéricos da tabela, chega-se às seguintes conclusões:

(i) Quando havia adjunto adverbial, as ordens predominantes eram XVSO e XVOS.

(ii) Quando havia um possível locativo nulo, a ordem predominante era (X)VSO. Esse fato demonstra, mais uma vez, que a presença do objeto $(\mathrm{O})$ após a estrutura VS era bastante expressiva.

18 O "x" não é considerado LOC. Geralmente ele aparece como um aposto ou como um elemento que não traz maiores detalhes, não sendo, portanto, relevante para a análise desta dissertação. 
(iii) Quando havia um pronome relativo precedendo a estrutura VS, a única ocorrência de inversão locativa era na ordem $\operatorname{XVS}(\mathrm{O}) .{ }^{19}$ Cabe destacar, neste caso, que o verbo era transitivo, porém o objeto na oração apresentava a configuração nula. Mais uma vez, ressalte-se o fato de o objeto (O) suceder a estrutura VS.

(iv) Quando havia uma conjunção precedendo a estrutura VS, a ordem era sempre contígua, isto é, sem a presença de qualquer elemento entre o verbo (V) e o sujeito (S). As ordens predominantes eram XVS(O), XVSO e XOVS. A configuração nula do objeto foi bastante expressiva, representando $50 \%$ dos dados de inversão locativa com verbos transitivos e com conjunção precedendo a estrutura VS. Ademais, destaque-se, mais uma vez, a ocorrência da ordem XVSO, com o objeto (O) sucedendo a estrutura VS.

De um modo geral, a tabela 18 evidencia que os dados do corpus desta dissertação, para orações na ordem VS com verbos transitivos, apresentaram ordens não encontradas nos dados de Gravina (2014). Essas ordens, principalmente aquelas em que o objeto (O) sucedia a estrutura VS, não foram encontradas por Gravina (2014) nem no Jornal Mineiro, jornal do século XIX que circulava em uma região muito próxima da que circulava o Jornal Matutina Meyapontense, jornal a partir do qual foi obtido o corpus desta dissertação. ${ }^{20}$

\subsubsection{Ordem VS com verbos inacusativos}

Os verbos inacusativos, segundo Duarte (2003), são aqueles monoargumentais que selecionam apenas um argumento interno. O nome inacusativo foi dado a esses verbos porque, apesar de eles selecionarem um DP, argumento interno, eles são incapazes de atribuir caso acusativo a este DP. Por causa dessa incapacidade, o DP, argumento interno, pode ocupar a posição de Spec de IP para, assim, receber caso nominativo.

No corpus formado pela análise do Jornal Matutina Meyapontense (MM), estão presentes 16 orações na ordem VS com verbos inacusativos. Ao analisar essas orações levando-se em consideração também a natureza do elemento que precedia VS, obteve-se um

19 (...) entaõ desejaria que se fisessem jurar os Litigantes, como fasia Licinio Nepos por orde do Senado, se tinhaõ dado dinheiro adiantado para serem castigados os Letrados (...). [XVS(O)] (MM, Edição 22, p. 4)

20 Não nos deteremos na explicação para as derivações de estruturas com ordem XVSO ou XVOS com elementos tais como pronomes relativos ou advérbios interrogativos na primeira posição. Para análises sobre essas ordens ver Lobato 1998, Figueiredo Silva 1996, Galves 2001, entre outros. 
maior detalhamento dos dados. A partir dessa sistematização, construiu-se a tabela 19, em que se considerou até duas casas decimais para os valores percentuais.

Tabela 19 - Número de orações na ordem VS com verbos inacusativos no

Jornal Matutina Meyapontense

(Século XIX - 1830)

\begin{tabular}{ccccc}
\hline \multicolumn{5}{c}{ Elemento que precede VS } \\
& $\begin{array}{c}\text { Elemento manifesto } \\
\text { (Adjunto adverbial) }\end{array}$ & Possível locativo nulo & Pronome relativo & Conjunção \\
\hline \multirow{2}{*}{$V S$} & $10 / 16$ & $2 / 16$ & $2 / 16$ & $2 / 16$ \\
& $62,50 \%$ & $12,50 \%$ & $12,50 \%$ & $12,50 \%$ \\
\hline
\end{tabular}

A tabela 19 evidencia um número de orações na ordem VS com verbos inacusativos não tão equânime quanto às orações na ordem VS com verbos transitivos. Observa-se que o maior número dessas inversões com verbos inacusativos ocorria quando, imediatamente antes da estrutura VS, havia um adjunto adverbial. Essa expressividade correspondeu a $62,50 \%$ do total dos dados analisados de oração VS com verbos inacusativos. As ocorrências de inversões com os outros parâmetros sobre a natureza do elemento que precedia a estrutura VS, apesar de equânimes, não foram tão expressivas, quando comparadas à realização de ordem VS com adjunto adverbial.

As 10 orações na ordem VS com verbos transitivos em que o elemento que precedia VS era um adjunto adverbial manifesto estão dispostas em (68), a seguir:

(68) a. Com isto taõ bem podem fazer ver no povo, que Deos estando em toda aparte, e enchendo todo o Mundo, faz-se desnecessaria a peregrinaçaõ de Meca, e nisto pode perigar a nossa Crença. (XVS)

(MM, Edição 4, p. 4)

b. (...) que á elle naõ poderiã̃ chegar os clamores contra a injustiça, ou Correpções administrativas, se naõ depois de grandes males estarem já feitos (...). (XVS)

(MM, Edição 11, p. 3)

c. Em hum dia, quando eu, repetia a Oraçaõ - Sacrosantae, et individuae Trinitati 
- chegou á Caza hum meu Amigo, Ministro do mesmo Culto, e notou o meu procedimento em recitar esta Oraçaõ, que elle chamou supersticioza. ( $\mathrm{XVxS})$

(MM, Edição 14, p. 3)

d. Nos Calamitosos tempos de Manoel Ignacio de Sampaio chegava o Correio sempre de noite (...). (XVS)

(MM, Edição 17, p. 6)

e. (...) emquanto porem nã̃ chega a trovoada, hirei me divertindo com os Capitulos do Correspondencia do Sapientissimo Sr. Zeloso. (XVS)

(MM, Edição 18, p. 4)

f. Num pequeno lugar da Provincia do Minho e o Portugal, falleceu ultimamente hum moço, que passava por Constitucional. (XVXS)

(MM, Edição 20, p. 4)

g. Naõ tardou muito que nã̃ aparecesse o Diabo (...). (XVS)

(MM, Edição 20, p. 4)

h. Quando a Vos publica tinha espalhado a noticia, que chegou até o Arraial, onde vivo, que na Cidade existia hum Testa de ferro, de quem certo Sugeito (...). (XVS)

(MM, Edição 27, p. 4)

i. Porque ainda existem homens do outro mundo, que se fingem raposas, sendo lobos devoradores. (XVS)

(MM, Edição 39, p. 2)

j. No dia 5 do mêz de Julho, pelas três horas da tarde, acabou os seus dias, na idade de $65 \operatorname{anos}(\ldots)$. (XVS)

(MM, Edição 54, p. 4)

As 2 orações na ordem VS com verbos inacusativos em que o elemento que precedia a estrutura VS era um possível locativo nulo estão dispostas em (69). 
(69) a. Sendo livre, por este modo, a Imprensa, apparecerã escriptores, que aprezentarã̃ factos de historia (...). [(X)VS]

(MM, Edição 4, p. 4)

b. (...) appellou da Sentença para o Juizo Superior; subirã̃ os Autos a concluzaõ no dia 12 de Dezembro (...). [(X)VS]

(MM, Edição 12, p. 3)

As 2 orações na ordem VS com verbos inacusativos em que o elemento que precedia VS era um pronome relativo estão dispostas em (70), a seguir:

(70) a. (...) seguio todo o Cotejo ao qual se tinha reunido o EXM. Prelado, para a Salla do Docel, onde estava o Angusto Retrato de Sua Magestade O Imperador, ao Qual se dirigiaõ todos as de mostraçoens de amor e respeito devidos ao seo verdadeiro Original. (XVS)

(MM, Edição 1, pp. 3-4)

b. (...) de que nasciã̃ differentes refflexoens, e moralidades. (XVS)

(MM, Edição 18, p. 4)

As 2 orações na ordem VS com verbos inacusativos em que o elemento que precedia VS era uma conjunção estão dispostas em (71), a seguir:

(71) a. (...) exaltou-se a invençaõ de hum novo môlho para peixe, fizeraõ-se saudes, riraõse duas, ou tres historias insipidas, e foraõ todos dormir. (XVSv)

(MM, Edição 11, p. 4)

b. E se me refferio, que quando entrava o Cirurgiaõ Mor da Provincia Antonio Luiz

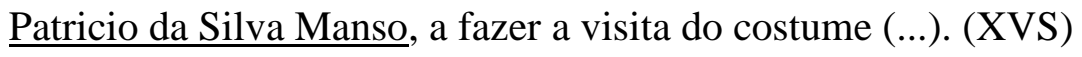

(MM, Edição 40, p. 4)

Os 16 dados permitem também que se analise a ordem dos elementos que integram cada oração na ordem VS com verbos inacusativos. Para uma melhor visualização 
da ordem desses elementos, elaborou-se a tabela 20, com a quantidade de cada ordem, em que se considerou até duas casas decimais para os valores percentuais.

Tabela 20 - Ordem dos elementos em orações na ordem VS com verbos inacusativos no Jornal Matutina Meyapontense (Século XIX - 1830)

\begin{tabular}{|c|c|c|c|c|}
\hline \multirow[b]{2}{*}{$X$} & \multicolumn{3}{|c|}{ Contiguidade (VS) } & \multirow{2}{*}{$\begin{array}{c}\text { Não-contiguidade }(V-S) \\
X V x S\end{array}$} \\
\hline & $X V S$ & $(X) V S$ & $X V S v$ & \\
\hline Adjunto adverbial & $\begin{array}{l}8 / 10 \\
80 \%\end{array}$ & - & $\begin{array}{c}0 / 10 \\
0 \%\end{array}$ & $\begin{array}{l}2 / 10 \\
20 \%\end{array}$ \\
\hline Possível locativo nulo & - & $\begin{array}{c}2 / 2 \\
100 \%\end{array}$ & - & - \\
\hline Pronome relativo & $\begin{array}{c}2 / 2 \\
100 \%\end{array}$ & - & $\begin{array}{l}0 / 2 \\
0 \%\end{array}$ & $\begin{array}{l}0 / 2 \\
0 \%\end{array}$ \\
\hline Conjunção & $\begin{array}{c}1 / 2 \\
50 \%\end{array}$ & - & $\begin{array}{c}1 / 2 \\
50 \%\end{array}$ & $\begin{array}{l}0 / 2 \\
0 \%\end{array}$ \\
\hline
\end{tabular}

A tabela 20 sistematiza o que se encontrou nos dados sobre a ordem dos elementos de orações na ordem VS com verbos inacusativos no Jornal Matutina Meyapontense. A partir da observação dos dados numéricos da tabela, chega-se às seguintes conclusões:

(i) Quando havia adjunto adverbial precedendo VS, a ordem predominante era XVS.

(ii) Quando havia um possível locativo nulo, a única ordem possível, logicamente, era $(\mathrm{X}) \mathrm{VS}$.

(iii) Quando havia um pronome relativo precedendo a estrutura VS, a única ocorrência de ordem VS, logicamente, era na ordem XVS.

(iv) Quando havia uma conjunção precedendo a estrutura VS, as ocorrências de oração na ordem VS eram XVS e XVSv. A sentença que se apresentava na ordem XVSv era a que está disposta em (71a): "e foraõ todos dormir". 
De um modo geral, a tabela 20 evidencia que os dados do corpus desta dissertação, para orações na ordem VS com verbos inacusativos, apresentaram, basicamente, a ordem XVS. Essa análise corrobora a literatura corrente que afirma que a ordem VS e as inversões locativas, ambas com verbos inacusativos, sempre foram bastante produtivas (Nascimento, 1984; Kato \& Tarallo, 1987 e 1993; Berlinck, 1999; Pilati, 2002 e 2006; Gravina, 2014).

\subsubsection{Ordem VS com verbos ser/estar}

Os verbos ser/estar foram separados, uma vez que estabelecem relações diferenciadas das demais categorias. No corpus formado pela análise do Jornal Matutina Meyapontense (MM), estão presentes 9 orações na ordem VS com os verbos ser/estar. Ao analisar as inversões com esses verbos levando-se em consideração também a natureza do elemento que precedia VS, obteve-se um maior detalhamento dos dados. A partir dessa sistematização, construiu-se a tabela a seguir, em que se considerou até duas casas decimais para os valores percentuais:

Tabela 21 - Número de orações na ordem VS com verbos ser/estar no Jornal Matutina Meyapontense (Século XIX - 1830)

\begin{tabular}{ccccc}
\hline \multicolumn{5}{c}{ Elemento que precede VS } \\
& $\begin{array}{c}\text { Elemento manifesto } \\
\text { (Adjunto adverbial) }\end{array}$ & Possivel locativo nulo & Pronome relativo & Conjunção \\
\hline \multirow{2}{*}{ VS } & $4 / 9$ & $1 / 9$ & $2 / 9$ & $2 / 9$ \\
& $44,44 \%$ & $11,11 \%$ & $22,22 \%$ & $22,22 \%$ \\
\hline
\end{tabular}

A tabela 21 evidencia um maior número de orações na ordem VS com os verbos ser/estar quando, imediatamente antes da estrutura VS, havia um adjunto adverbial. Essa expressividade correspondeu a 44,44\% do total dos dados analisados de orações na ordem VS com os verbos ser/estar. As ocorrências de inversões com os outros parâmetros sobre a natureza do elemento que precedia a estrutura VS foram relativamente expressivas, a exceção do parâmetro do possível locativo nulo.

As 4 orações na ordem VS com os verbos ser/estar em que o elemento que precedia VS era um adjunto adverbial estão dispostas em (72). 
(72) a. (...) para a Salla de Docel, onde estava o Angusto Retrato de Sua Magestade O IMPERADOR (...). (XVS)

(MM, Edição 1, p. 3)

b. Entrei em huã Casa, onde estavã̃ dous Sugeitos conversando na materia. (XVS)

(MM, Edição 6, p. 2)

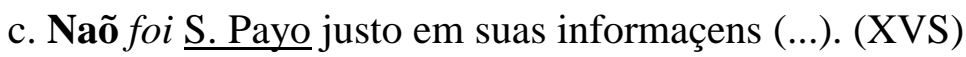

(MM, Edição 36, p. 4)

d. Em seu Reinado naõ esteve em uso a Proteçaõ ; e a amisade, que conheceo, e cultivou, naõ prevaleceo á sua vista ao merecimento menos artectuoso, e menos agradavel; se fez graça aos que estimava, os ogares mais importantes só foraõ dados aos homens mais capases. (XVS)

(MM, Edição 54, p. 3)

A única oração na ordem VS com os verbos ser/estar em que o elemento que precedia VS era um possível locativo nulo está disposta em (73), a seguir:

(73) Seriã̃ estimadas as bellas artes, e fariaõ juntamente a vossa gloria, e a vossa riqueza $(\ldots) .[(\mathrm{X}) \mathrm{VS}]$

(MM, Edição 11, p. 4)

As 2 orações na ordem VS com os verbos ser/estar em que o elemento que precedia VS era um pronome relativo/ conjunção integrante estão dispostas em (74).

(74) a. Mas catholicamente creio que isso só fariaõ Almas vis, e gente infima, assim como creio piedosamente, que seria injusta a queixa, que alguns fasiaõ de faltas em suas correspondencias. $(\mathrm{XVxS})$

(MM, Edição 36, p. 4) 
b. He verdade que alguem pensava, que seria mais bem guardada a mala do Correio na Caza da Administraçaõ (...). (XVxS)

(MM, Edição 36, p. 4)

As 2 orações na ordem VS com os verbos ser/estar em que o elemento que precedia VS era uma conjunção estão dispostas em (75), a seguir:

(75) a. (...) e sendo notoria a ínopia (...). (XVxS)

(MM, Edição 34, p. 4)

b. (...) por isso que sendo publica a sua falta de caridade, nada se deve esperar de seus cuidados (...). (XVxS)

(MM, Edição 40, p. 4)

Os 9 dados mostram sempre a presença de algum elemento que antecedia a estrutura VS. A natureza desses elementos, como se pode observar, era sempre de um adjunto adverbial, ou de um pronome relativo ou de uma conjunção. No único caso de ocorrência do parâmetro com possível locativo nulo, pode-se inferir a ideia de termos adverbiais e temporais, como lá, agora, neste instante, naquele momento, entre outros, no lugar de X. Nesse sentido, expõem-se, a seguir, novamente a sentença enumerada em (73):

(73) (Lá) Seriã̃ estimadas as bellas artes, e fariaõ juntamente a vossa gloria, e a vossa riqueza $(\ldots) .[(\mathrm{X}) \mathrm{VS}]$

(Agora) Seriaõ estimadas as bellas artes, e fariaõ juntamente a vossa gloria, e a vossa riqueza $(\ldots) .[(\mathrm{X}) \mathrm{VS}]$

(Naquele momento) Seriã̃ estimadas as bellas artes, e fariaõ juntamente a vossa gloria, e a vossa riqueza (...). [(X)VS]

(MM, Edição 11, p. 4)

Os 9 dados permitem também que se analise a ordem dos elementos que integram cada oração na ordem VS com os verbos ser/estar. Para uma melhor visualização da 
ordem desses elementos, elaborou-se a tabela 22 , com a quantidade de cada ordem, em que se considerou até duas casas decimais para os valores percentuais.

Tabela 22 - Ordem dos elementos em orações VS com verbos ser/estar no Jornal Matutina Meyapontense (Século XIX - 1830)

\begin{tabular}{|c|c|c|c|}
\hline & \multicolumn{2}{|c|}{ Contiguidade (VS) } & \multirow{2}{*}{$\begin{array}{c}\text { Não-contiguidade }(V-S) \\
X V x S\end{array}$} \\
\hline$X$ & $X V S$ & $(X) V S$ & \\
\hline Adjunto adverbial & $\begin{array}{c}4 / 4 \\
100 \%\end{array}$ & - & $\begin{array}{c}0 / 4 \\
0 \%\end{array}$ \\
\hline Possível locativo nulo & - & $\begin{array}{c}1 / 1 \\
100 \%\end{array}$ & - \\
\hline Pronome relativo & $\begin{array}{l}0 / 2 \\
0 \%\end{array}$ & - & $\begin{array}{c}2 / 2 \\
100 \%\end{array}$ \\
\hline Conjunção & $\begin{array}{l}0 / 2 \\
0 \%\end{array}$ & - & $\begin{array}{c}2 / 2 \\
100 \%\end{array}$ \\
\hline
\end{tabular}

A tabela 22 sistematiza o que se encontrou nos dados sobre a ordem dos elementos das orações na ordem VS com os verbos ser/estar no Jornal Matutina Meyapontense. A partir da observação dos dados numéricos da tabela, chega-se às seguintes conclusões:

(i) Quando havia um adjunto adverbial, a única ordem possível era XVS.

(ii) Quando havia um possível locativo nulo, a única ordem possível era (X)VS.

(iii) Quando havia um pronome relativo precedendo a estrutura VS, as únicas ocorrências de ordem VS era XVxS. A seguir, apresentam-se novamente essas duas orações, como já exposto em (74a) e em (74b):

(74) a. Mas catholicamente creio que isso só fariaõ Almas vis, e gente infima, assim como creio piedosamente, que seria injusta a queixa, que alguns fasiaõ de faltas em suas correspondencias. $(\mathrm{XVxS})$

(MM, Edição 36, p. 4) 
b. He verdade que alguem pensava, que seria mais bem guardada a mala do Correio na Caza da Administraçaõ (...). (XVxS)

(MM, Edição 36, p. 4)

Como se pode observar, o elemento "x", que aparece entre o verbo (V) e o sujeito (S), mantém, nas duas ocorrências, uma ligação com o sujeito.

(iv) Quando havia uma conjunção precedendo a estrutura VS, as únicas ocorrências de inversão locativa era na ordem XVxS. A seguir, apresentam-se novamente essas duas orações, como já exposto em (75a) e em (75b):

(75) a. (...) e sendo notoria a ínopia (...). (XVxS)

(MM, Edição 34, p. 4)

b. (...) por isso que sendo publica a sua falta de caridade, nada se deve esperar de seus cuidados (...). (XVxS)

(MM, Edição 40, p. 4)

Como se pode observar, o elemento " $\mathrm{x}$ " que aparece entre o verbo (V) e o sujeito (S) - assim como exposto no tópico anterior, referente ao pronome relativo - mantém, nas duas ocorrências, uma ligação com o sujeito.

De um modo geral, a tabela 22 evidencia que os dados do corpus desta dissertação, para orações na ordem VS com os verbos ser/estar, apresentaram a ordem XVS e $\mathrm{XVxS}$.

\subsubsection{Ordem VS com verbos inergativos}

Os verbos inergativos são aqueles que selecionam apenas um argumento externo. Sobre a ordem verbo-sujeito (VS) e as inversões locativas, Gravina (2014), como visto no capítulo 2 desta dissertação, defende, com base nos seus corpora, que esses verbos não favoreciam a inversão do sujeito.

Em razão de o corpus desta dissertação não apresentar qualquer dado de ordem VS ou de inversão locativa com verbos inergativos, não será possível a realização de uma análise comparativa com os resultados de Gravina (2014). Destaque-se, no entanto, que, em 
pesquisas futuras, continuar-se-á procurando por inversões com esse tipo de verbo no português do centro-oeste brasileiro no século XIX.

\subsection{Inversões locativas nos dados do corpus}

Como visto na seção anterior, os dados do corpus obtido no Jornal Matutina Meyapontense, jornal que circulou na região Centro-Oeste brasileira na metade do século XIX, mostram que, já naquela época, era possível encontrar inversões locativas. Veja, a seguir, um exemplo de inversão locativa - o qual foi retomado da seção anterior, mantendo-se a mesma numeração:

(65) a. Ignora o Sr. Redactor o facto do Rebouças, de que fui testemunha ocular (...). [(X)VSO]

(MM, Edição 17, p. 3)

Em (65a), verifica-se que, apesar de não ter aparecido um elemento locativo/temporal manifesto, a posição imediatamente anterior ao verbo pode ser preenchida por um elemento locativo/temporal foneticamente nulo (agora, neste momento). Veja a seguir essa mesma sentença (65a) com a presença desses elementos:

(65) a. (AGORA/NESTE MOMENTO) Ignora o Sr. Redactor o facto do Rebouças, de que fui testemunha ocular (...). [(X)VSO]

(MM, Edição 17, p. 3)

Há diversos outros exemplos que podem ser analisados como inversões locativas, principalmente os com verbos inacusativos. Seguem os exemplos, os quais foram retomados da seção anterior mantendo-se a numeração:

(68) a. Com isto taõ bem podem fazer ver no povo, que Deos estando em toda aparte, e enchendo todo o Mundo, faz-se desnecessaria a peregrinaçaõ de Meca, e nisto pode perigar a nossa Crença. (XVS)

(MM, Edição 4, p. 4)

d. Nos Calamitosos tempos de Manoel Ignacio de Sampaio chegava o Correio sempre de noite (...). (XVS) 
f. Num pequeno lugar da Provincia do Minho e o Portugal, falleceu ultimamente hum moço, que passava por Constitucional. (XVXS)

(MM, Edição 20, p. 4)

h. Quando a Vos publica tinha espalhado a noticia, que chegou até o Arraial, onde vivo, que na Cidade existia hum Testa de ferro, de quem certo Sugeito (...). (XVS)

(MM, Edição 27, p. 4)

Em (68a), (68d), (68f) e (68h), as expressões em negrito representam elementos locativos/temporais manifestos imediatamente anterior ao verbo, respectivamente expressas a seguir: (i) nisto; (ii) Nos Calamitosos tempos de Manoel Ignacio de Sampaio; (iii) Num pequeno lugar da Provincia do Minho e o Portugal; e (iv) na Cidade. Esses elementos preenchem a posição de $\mathrm{C}$.

Sobre o preenchimento da posição de C, cabe mencionar que, no corpus desta dissertação, foram encontradas sentenças que - embora não fossem propriamente inversões locativas, já que os elementos anteriores ao verbo não eram locativos/temporais - possuíam a posição de $\mathrm{C}$ preenchida por algum elemento. ${ }^{21}$ Observou-se que esses elementos pertenciam

21 De acordo com Duarte \& Kato (2014, p. 13), no Projeto do Português Culto Falado, uma das conclusões a que se chegou foi que o PB falado evita deixar a posição antes do verbo vazia (Kato 2002) - como ilustrado em (38), com a numeração das autoras mantidas: V1

(38) a. \%Durmo cedo.

b. Conserta sapato(s).

c. \%Vira à esquerda.

d. \%Dormem ali os meninos.

e. Chove em São Paulo.

f. Furou o pneu do Hamilton.

g. Xinguei o cara.
$\mathrm{V} 2$

a'. Eu durmo cedo.

b'. Aqui conserta sapato.

c'. Cề vira à esquerda.

d'. Ali dormem os meninos

e'. São Paulo chove.

f'. O Hamilton furou o pneu.

g. Daí xinguei o cara.

Duarte \& Kato (2014, p. 13) afirmam que o padrão V(X)S (cf. 38d) não ocorre, mas, segundo elas, se houver algum elemento antes, ele pode ocorrer, como em (38d'). Se nenhum constituinte sintático ocorrer antes do verbo, algum preenchedor discursivo ali ocorrerá, como no exemplo (38g). A conclusão das autoras foi que o PB não é uma língua V2, mas uma língua de efeito V2, ditado pela prosódia. Duarte \& Kato (2014) destacam que o elemento que impede o padrão V1 não precisa ser um XP, podendo ser um núcleo, como se observa no PB falado, o que explica por que na língua escrita a restrição ao NS parece não existir.

(39) a. não sei exatamente se ele tem noção de tempo.

b. só assistiu três vezes?

c. já apareceu no escritório.

A solução proposta em Kato (2002) e Duarte \& Kato (2013) para o PB falado é que haveria no PB, ao lado da restrição "Evite pronome referencialmente deficiente" em Forma Lógica, a restrição "Evite V1" em Forma Fonética. Qualquer uma das restrições nas interfaces, segundo as autoras, poderia ser violada, mas haveria uma gradação de aceitabilidade conforme as duas restrições sejam respeitadas ou apenas uma. 
à categoria dos pronomes relativos e à das conjunções. Veja, a seguir, alguns exemplos dessas sentenças, os quais foram retomados da seção anterior mantendo-se a numeração:

(70) a. (...) seguio todo o Cotejo ao qual se tinha reunido o EXM. Prelado, para a Salla do Docel, onde estava o Angusto Retrato de Sua Magestade O Imperador, ao Qual se dirigiaõ todos as de mostraçoens de amor e respeito devidos ao seo verdadeiro Original. (XVS)

(MM, Edição 1, pp. 3-4)

(71) a. (...) exaltou-se a invençaõ de hum novo môlho para peixe, fizeraõ-se saudes, riraõse duas, ou tres historias insipidas, e fora ̃o todos dormir. (XVSv)

(MM, Edição 11, p. 4)

As sentenças em (70a) e em (71a) mostram a posição de $\mathrm{CP}$ preenchida respectivamente pelo pronome relativo qual e pela conjunção $e .{ }^{22}$ Esse preenchimento, por hipótese, facilita o movimento do verbo. Análises minuciosas de orações VS em que o elemento imediatamente anterior ao verbo é um pronome relativo ou uma conjunção serão feitas em trabalhos futuros.

Por fim, mencione-se que, no corpus desta dissertação, também se verificou inversão locativa com a presença de um locativo/temporal antes do verbo, sendo esse o verbo “estar". Veja a seguir esse exemplo em (72d), em que foi mantida a numeração utilizada na seção anterior:

(72) d. Em seu Reinado nã̃ esteve em uso a Proteçaõ ; e a amisade, que conheceo, e cultivou, naõ prevaleceo á sua vista ao merecimento menos artectuoso, e menos agradavel; se fez graça aos que estimava, os ogares mais importantes só foraõ dados aos homens mais capases. (XVS)

Diante das análises desta seção e da anterior, as quais foram realizadas a partir do tipo de sentenças e do tipo de verbo, observa-se que, no português do centro-oeste brasileiro do século XIX, havia uma maior ocorrência de orações VS com o verbo na segunda posição e com algum elemento na primeira. Gravina (2014) afirma que, em seus dados, esses elementos anteriores ao verbo eram locativos/temporais. O corpus desta dissertação mostra,

22 Sobre o preenchimento da posição de C por algum elemento diverso de um locativo/temporal, nas orações com ordem VS, ver Lobato (1986) e Figueiredo Silva (1996). 
no entanto, que esses elementos $\mathrm{X}$ também poderiam ser pronomes relativos e conjunções. Em relação à produtividade na língua, Gravina (2014) afirma que sentenças VOS possuíam maior ocorrência que VS ou OVS. O corpus desta dissertação mostra, no entanto, que a ordem VSO possuía uma maior produtividade, quando comparada às ordens OVS e VOS. Uma análise mais detalhada sobre essas questões será feita em trabalhos posteriores.

\subsection{Inversão locativa e parâmetro pro-drop}

Chomsky (1981), como visto no capítulo 1 desta dissertação, aponta cinco características essenciais para a marcação positiva do parâmetro pro-drop: (i) sujeito nulo; (ii) inversão livre do sujeito; (iii) movimento longo do sujeito, a partir da ilha $Q u-$; (iv) pronome resumptivo vazio em orações encaixadas; e (v) aparente violação do filtro trat-trace. Com base característica da inversão livre do sujeito e na análise dos dados do corpus desta dissertação, buscar-se-á mostrar, de forma sumária, que não há relação da ordem VS com o parâmetro pro-drop, como defendido por Corr (2012).

Os dados do corpus desta dissertação, como exposto na seção anterior, apresentam casos de inversão locativa. Nas inversões locativas, o elemento que antecede a estrutura VS é um locativo que ocupa a posição SpecT. Por hipótese, esse fato revela a tendência, ou a consumação, de o português brasileiro (PB) buscar o preenchimento da posição do sujeito, mesmo que com elementos foneticamente nulos.

O fato de inversões locativas poderem ser encontradas no português brasileiro, desde o século XIX na região centro-oeste brasileira, revela que esse tipo de inversão "livre" não pode ser apenas uma propriedade de línguas de sujeito nulo consistente. Dessa forma, estes casos de inversão não parecem ser uma consequência direta do parâmetro pro-drop, como defendido por Corr (2012).

\subsection{Síntese do capítulo}

Neste capítulo, foram apresentados os resultados das análises quantitativas efetuadas no corpus escrito do Jornal Matutina Meyapontense sobre as orações na ordem (X)VS, com X manifesto ou nulo. Além disso, em relação ao aspecto qualitativo, defendeu-se - de maneira sumária, já que o objetivo central desta dissertação diz respeito ao aspecto quantitativo - dois argumentos: (i) o de que, já no século XIX, no centro-oeste brasileiro, as orações na ordem verbo-sujeito (VS) poderiam ser inversão locativa, como defende Pilati (2006) para os dados do português brasileiro (PB) atual; e (ii) o de que não havia relação entre ordem VS e parâmetro pro-drop, como defende Corr (2012). 
Foram apresentadas, inicialmente, informações sobre a constituição da língua no centro-oeste brasileiro até o século XIX. Em seguida, foram apresentados os detalhes sobre o corpus deste trabalho, juntamente com a metodologia utilizada nos dados obtidos. Após essa abordagem, foram apresentadas as análises quantitativas efetuadas no corpus obtido. Por fim, foram defendidos os dois argumentos explicitados no parágrafo anterior. 


\section{CONCLUSÃO}

O presente trabalho, sob a perspectiva da Teoria Gerativa, examinou aspectos sintáticos e semânticos de sentenças com ordem verbo-sujeito (VS) no português brasileiro (PB) na região Centro-Oeste durante o século XIX. Dada a hipótese de que o processo sóciohistórico favoreceu situações específicas de contato e de isolamento linguístico [cf. Borges, Salles \& Pilati (2012)], observou-se que esse contexto de suposto isolamento pode ter favorecido o licenciamento da ordem VS, já que nessa época havia construções nessa configuração.

A respeito especificamente do fenômeno da ordem VS, foram apresentadas as constatações de Berlinck (1989), de Nascimento (1984), de Kato \& Tarallo (1987), de Kato \& Tarallo (1993) e de Pilati (2002). Como visto, Berlinck (1989), funcionalista, afirma que referida ordem diminuiu com o decorrer do tempo, especialmente com verbos transitivos. Nascimento (1984), Kato \& Tarallo (1987) e Kato \& Tarallo (1993), gerativistas, afirmam, respectivamente, que a ordem VS: (i) deve ser entendida como "interpretação de lista", ocorrendo apenas com verbos inergativos e inacusativos e (ii) seria resultado de diferentes estruturas. Pilati (2002), por sua vez, que afirma que ordem VS é, sim, resultado de diferentes estruturas, inclusive com verbos transitivos e objeto(s) manifesto(s).

Os trabalhos expostos no capítulo 1 mostraram que o fenômeno da ordem VS estava diretamente relacionado ao parâmetro pro-drop, com exceção de Pilati (2002), que começa a observar que as orações na ordem VS eram inversões locativas, e que, portanto, não tinham qualquer relação com o parâmetro pro-drop. É importante destacar que, já em Berlinck (1989), sem as observações iniciais de Pilati (2002), os casos de VS que ainda persistiam no PB não eram apenas de VS clássico, como o das demais línguas românicas, mas alguns eram casos de inversão locativa, um fenômeno não previsto dentro do parâmetro.

Sobre as inversões locativas, foram apresentadas no capítulo 2 as principais características desse fenômeno. Levin \& Rappaport (1995), como visto, defendem que as características das inversões locativas do inglês, que são semelhantes às do PB, são as seguintes: (i) são orações apresentativas num sentido mais amplo, ou seja, inserem o termo menos familiar, que não precisa ser necessariamente novo na situação do discurso; (ii) apresentam a ordem PP VP NP; (iii) contêm PP locativo ou direcional; (iv) ocorrem tipicamente com verbos inergativos ou inacusativos; (v) possuem verbos informacionalmente leves; e (vi) contêm sujeitos desagentivizados. Os autores afirmam, ainda, que os verbos 
transitivos apenas são permitidos quando formam estruturas fixas, como take place e take root.

Pilati (2002) e Pilati (2006), como visto, defendem que, no PB, o fato de haver sempre um X (manifesto ou nulo) à esquerda do verbo faz com que orações na ordem VS se pareçam inversões locativas. Pilati (2002) e Pilati (2006) afirmam que orações com ordem VS: (i) não são usadas em contextos de respostas a perguntas $Q u$ com foco estreito, ocorrendo, portanto, em contextos de foco largo; (ii) são licenciadas com mais frequência com verbos inacusativos, como atesta a maioria dos estudos variacionistas (cf. Lira, 1986; Berlinck, 1989; Pezatti, 1993; Coelho, 2000; Alberton, 2001); e (iii) podem ocorrer, no entanto, com verbos inergativos e transitivos, como defendido por Votre \& Naro (1999) e atestado por Pilati (2002) e por Scherre, Naro \& Cardoso (2007).

Também no capítulo 2 foi visto que Pilati (2006) - que segue a análise descritiva de Pinto (1997) para o Italiano - propõe que as orações com ordem VS do PB: a) são tipos de inversão locativa e b) apresentam um elemento de natureza locativa, em posição pré-verbal (se nulo, identificado como um proLOC).

Os dados do corpus desta dissertação mostraram, no capítulo 3, que no português do centro-oeste brasileiro, no século XIX, a ordem VS aparecia como VS clássica e também como inversão locativa. De forma geral, a estrutura VS aparecia em: (i) orações parentéticas; (ii) orações com verbos transitivos; (iii) orações com verbos inacusativos; (iv) orações com verbos ser/estar; e (v) orações com verbos inergativos.

Ainda sobre a análise dos dados do corpus deste trabalho, observou-se que, sempre imediatamente antes da estrutura VS, havia algum elemento. Esse elemento, como observado, poderia ser: (i) um elemento manifesto (adjunto adverbial); (ii) um possível locativo nulo; (iii) um pronome relativo; ou (iv) uma conjunção.

Em relação à produtividade na língua - ao contrário de Gravina (2014), que afirma que sentenças VOS possuíam maior ocorrência que VS ou OVS - o corpus desta dissertação mostrou que a ordem VSO possuía uma maior produtividade, quando comparada às ordens OVS e VOS. Uma análise mais detalhada sobre essas questões será feita em trabalhos posteriores.

Com base no trabalho de Corr (2012), observou-se que o fato de inversões locativas, como visto, poderem ser encontradas no português brasileiro desde o século XIX na região centro-oeste brasileira revela que o tipo de inversão "livre" não era apenas uma propriedade de línguas de sujeito nulo consistente. Dessa forma, esses casos de inversão não parecem ser uma consequência direta do parâmetro pro-drop. Esse fato revela, portanto, uma 
tendência, ou a consumação, de que o português brasileiro (PB), desde o século XIX, buscava o preenchimento da posição do sujeito, mesmo que com elementos foneticamente nulos. 


\section{BIBLIOGRAFIA}

ALBERTON, Cristiane (2001). O português falado no Rio Grande do Sul: a ordem verbosujeito. Dissertação de Mestrado. Passo Fundo: UFP.

ALEXIADOU, Artemis \& ANAGNOSTOPOULOU, Elena (1998). Parametrizing AGR: Word Order, V-Movement and EPP-Checking. In: Natural Language \& Linguistic Theory, $\mathrm{n}$. 16 (3), pp. 491-539.

ÂMBAR, Maria Manuela (1992). Para uma sintaxe da inversão verbo-sujeito em português. Lisboa: Edições Colibri.

BARBOSA, Maria do Pilar Pereira (1995). Null subjects. Dissertação de Pós-Doutorado. Cambridge: MIT.

BENINCÀ, Paola. (1988). Soggetto Posverbale. In: L. Renzi (ed.). Grande grammatica italiana di consultazione. Bologna: Il Mulino. pp. 122-126.

BERLINCK, Rosane de Andrade (1989). A construção V SN no português do Brasil: uma visão diacrônica do fenômeno da ordem. In: TARALLO, Fernando. (org.). Fotografias sociolingüísticas. Campinas: Pontes, pp. 95-112.

BORGES, Dalmo Vinícius Coalho (2008). Construções causativas no português do centrooeste nos séculos XVIII-XIX e no português atual. Dissertação de Mestrado. Brasília: UnB.

BORGES, Dalmo Vinícius Coalho; SALLES, Heloisa M. M. Lima; PILATI, Eloisa N. Silva (2012). O projeto O Centro-Oeste na história do Português Brasileiro : subsídios da sóciohistória ao estudo da mudança linguística e hipóteses de trabalho.. In: Cardoso; Scherre; Salles. (Org.). Linguagem e Sociedade. Belo Horizonte: Pontes, v. 1, pp. 1-15.

BRESNAN, Joan (1994). Locative inversion and the architecture of Universal Grammar. In: Language. ed. 70, pp. 72-131.

BRITTO, Helena de Souza (1998). Deslocamento à esquerda - resumptivo, sujeito, ordem SV $e$ a codificação sintática de juízo categórico e tético no português do Brasil. Tese de Doutorado. Campinas: UNICAMP.

CARVALHO. Adelmo de (2000). Pirenópolis: coletânea 1727-2000, história, turismo e curiosidades. Goiânia: Kelps.

CASTRO, Yeda Pessoa de (200?). A influência de línguas africanas no português brasileiro. Disponível em: <http://www.unipinhal.edu.br/biblioteca/Referencias_bibliog raficas_NBR_6023_2002.pdf>. Acessado em 16 de julho de 2014.

(2001). Falares africanos na Bahia. Rio de Janeiro: Topbooks.

CHAIM, Marivone Matos (1974). Os aldeamentos indígenas na Capitania de Goiás: sua importância na política de povoamento (1749-1811). Goiânia: Oriente. 
CHOMSKY, Noam (1965). Aspects of the theory of syntax. Cambridge: MIT. (1980). Reflexões sobre a linguagem. São Paulo: Cultrix.

(1981). Lectures on government and binding. Dordrecht: Foris.

(1982). Some concepts and consequences of the theory of government and binding. Cambridge: MIT.

(1986). Knowledge of language: its nature, origin and use. New York: Praeger, pp. 1-

50.

(1997). Novos horizontes no estudo da linguagem. In: DELTA, v. 13. n. esp. São Paulo. Disponível em <http://www.scielo.br/scielo.php?script=sci_arttext\&pid=S01

02-44501997000300002\&lng=pt\&nrm=iso>. Acesso em 14 out. 2014.

(1999). Derivation by phase. Cambridge: MIT.

CHOMSKY, Noam \& LASNIK, Howard (1977). Filters and control. In: Linguistic Inquiry, v. 11, pp. 425-504.

COELHO, Izete Lehmkuhl (2000). A ordem V SN em construções monoargumentais: uma restrição sintático-semântica. Tese de Doutorado. Florianópolis: UFSC.

CORR, Alice (2012). Subject inversion in Ibero-Romance. Tese de Doutorado. Departament of Theoretical and Applied Linguistics. University of Cambridge.

DUARTE, Maria Eugênia Lammoglia (1995). A perda do princípio "Evite Pronome" no português brasileiro. Tese de Doutorado. Campinas: UNICAMP.

(2003). A evolução na representação do sujeito pronominal em dois tempos. In: PAIVA, Maria da Conceição de \& DUARTE, Maria Eugênia Lamoglia (orgs.). Mudança lingüística em tempo real. Rio de Janeiro: Contracapa.

DUARTE, Maria Eugênia Lammoglia \& KATO, Mary Aizawa (2013). The lack of expletives in Brazilian Portuguese. Comunicação apresentada no Encontro do GT de Teoria da Gramática, USP.

(2014). Restrições na distribuição de sujeitos nulos no português brasileiro. In: Veredas: sintaxe das línguas brasileiras. vol. 18/1.

FIGUEIREDO SILVA, Maria Cristina (1996). A posição do sujeito no português brasileiro: frases finitas e infinitivas. Campinas: UNICAMP.

GALVES, Charlotte (2001). Ensaios sobre as gramáticas do português. Campinas: Unicamp.

GRAVINA, Aline Peixoto (2014). Sujeito nulo e ordem no português brasileiro: um estudo diacrônico-comparativo baseado em corpus. Tese de Doutorado. Campinas: UNICAMP. 
HORNSTEIN, Nobert; NUNES, Jairo; GROHMANN, Kleanthes (2005). Understanding minimalism. New York: Cambridge.

KATO, Mary Aizawa (2002). La gramática del portugués hablado: reflexiones sobre el uso de la lengua. In: Curcó, C.; Colín, M.; Groult, N; Herrera, L. (Eds.) Contribuciones a la lingüística aplicada em América Latina. México: CELE-UNAM, pp. 363-378.

KATO, Mary Aizawa \& TARALLO, Fernando (1987). Harmonia Trans-sistêmica: variação intra- e inter-linguística. In: Predição, n 1 , Campinas, pp. 1-41.

(1993/2003). The loss of VS syntax in brazilian portuguese. In: Schlieben-Lange, Villaça Lock, Jungbluth (orgs.). Dialog zwischen den Schulen. Münster: Nodus Publikationen.

KENEDY, Eduardo (2008). Gerativismo. In: MARTELLOTA, Mário Eduardo Toscano (Org.). Manual de linguística. v. 1. São Paulo: Contexto, pp. 127-140.

LEVIN, Beth \& RAPPAPORT, Malka Hovav (1995). Unaccusativity at the syntax-lexical semantics interface. Cambridge: MIT.

LIRA, Solange (1982). Nominal, pronominal and zero subjects in brazilian portuguese. Dissertação de Pós-Doutorado. University of Pennsylvania.

(1986). Subject postposition in portuguese. In: DELTA, v. 2, n. 1, pp. 17-36.

LOBATO, Lúcia Maria Pinheiro (1986). Sintaxe gerativa do português: da teoria padrão à teoria da regência e ligação. Belo Horizonte: Vigília.

MARINS, Juliana Esposito (2009). O parâmetro do sujeito nulo: uma análise contrastiva entre o português e o italiano. Dissertação de Mestrado. Rio de Janeiro: UFRJ.

MATTOS E SILVA, Rosa Virgínia (2004). Ensaios para uma sócio-história do português brasileiro. São Paulo: Parábola.

MENUZZI, Sergio de Moura (2004). A ordem verbo-sujeito no português do Brasil: para uma comparação das abordagens formalistas e funcionalistas. In: Revista da Anpoll, n. 16, p. 349384, jan./jun. São Paulo: Humanitas.

MODESTO, Marcello (2008). Topic prominence and null subjects. In: The limits of syntactic variation, v. 132.

NASCIMENTO, Milton do (1984). Sur la postposition du sujet dans le portugais du Brésil. Dissertação de Pós-Doutorado. Paris: Université de Paris VIII.

NAVES, Rozana Reigota \& PILATI, Eloisa Nascimento Silva (2013). Desenvolvendo a hipótese da cisão da categoria pronominal no português brasileiro. In: MOURA, Denilda \& Sibaldo, Marcelo A. Estudos e pesquisas em teoria da gramática. Maceió: EDUFAL, pp. 233-253. 
NEGRÃO, Esmeralda. V. \& VIOTTI, Evani (2000). Brazilian portuguese as a discourse oriented-language. In: KATO, M. A. \& NEGRÃO, E. V. (orgs.). Brazilian portuguese and the null subject parameter. Frankfurt/Madrid: Vervuert-Iberoamericana, pp. 105-125.

NICOLAU, Eunice (1995). As propriedades de sujeito nulo e ordem VS no português brasileiro. Tese de Doutorado. UNICAMP.

PALACIN, Luiz (1972). Goiás, estrutura e conjuntura numa capitania de Minas. Goiânia: Editora da Universidade Católica de Goiás.

PEDROZA, Jonathan Furtado (2010). Uma abordagem quantitativa da ordem verbo-sujeito no português do centro-oeste brasileiro nos séculos XVIII e XIX. Brasília: UnB.

PERLMUTTER, David (1976). Evidence for subject downgrading in portuguese. In:. (ed.). Readings in portuguese linguistics. Amsterdam: North Holland, pp. 157-189.

PEZZATI, Erotilde Goreti (1993). A ordem das palavras e o caráter nominativo/ergativo do português falado. In: ALFA, 37, pp. 159-178.

PILATI, Eloisa Nascimento Silva (2002). Sobre a ordem verbo-sujeito no português do Brasil. Dissertação de Mestrado. Brasília: UnB.

(2006). Aspectos sintáticos e semânticos das orações com ordem verbo-sujeito no português do Brasil. Tese de Doutorado. Brasília: UnB.

PINTO, Manuela (1994). Subjects in italian: distribuition and interpretation. In: R. BokBennema and C. Cremers (eds.). Linguistics in the Netherlands. Amsterdam: Benjamins.

(1997). Licencing and interpretation of inverted subjects in italian. Tese de Doutorado. LED, Ultrecht.

PONTES, Eunice (1986). O tópico no português do Brasil. Campinas: Pontes.

RIZZI, Luigi (1982). Issues in italian syntax. Dordrecht: Foris.

ROGRIGUES, Aryon Dall'Igna (1994). Línguas brasileiras: para o conhecimento das línguas indígenas. 2.ed. São Paulo: Edições Loyola.

(1996). As línguas gerais sul-americanas. In: PAPIA - Revista de Crioulos de Base Ibérica. Brasília, v.4, pp.6-18.

RODRIGUES, Cilene Aparecida Nunes (2004). Impoverished morphology and A-movement out of Case domains. Tese de Doutorado. Maryland: University of Maryland.

SCHERRE, Maria Marta Pereira; NARO, Anthony J. \& CARDOSO, Caroline Rodrigues (2007). O papel do tipo de verbo na concordância verbal no português brasileiro. In: DELTA: 23 (edição especial), pp. 283-317.

SHEEHAN, Michelle (2006). The EPP and null subjects in Romance. Dissertação de PósDoutorado. Newcastle University. 
(2010). 'Free' inversion in Romance and the Null Subject Parameter. In: T. Biberauer, A. Holmberg, I. Roberts and M. Sheehan (eds.). Parametric Variation: null subjects in Minimalist Theory. Cambridge: Cambridge University Press.

THOMAS, Earl W. (1969). The syntax of spoken brazilian portuguese. Nashville: Vanderbilt.

TORTORA, Christina (2001). Evidence for a null locative in Italian. In: G. Cinque and G. Salvi (eds.). Current studies in italian syntax: essays offered to Lorenzo Renzi. Amsterdam: Elsevier.

SARDINHA, Tony Berber (2000). Linguística de corpus: histórico e problemática. In: DELTA. São Paulo, v. 16, n. 2. Disponível em: <http://www.scielo.br/scielo.php?script=sci_ar ttext\&pid=S0102-44502000000200005\&lng=en\&nrm=iso>. Acesso em 16 de janeiro de 2014. 